\title{
Freshwater Mussels in Montana: Comprehensive Results from 3 years of SWG Funded Surveys
}

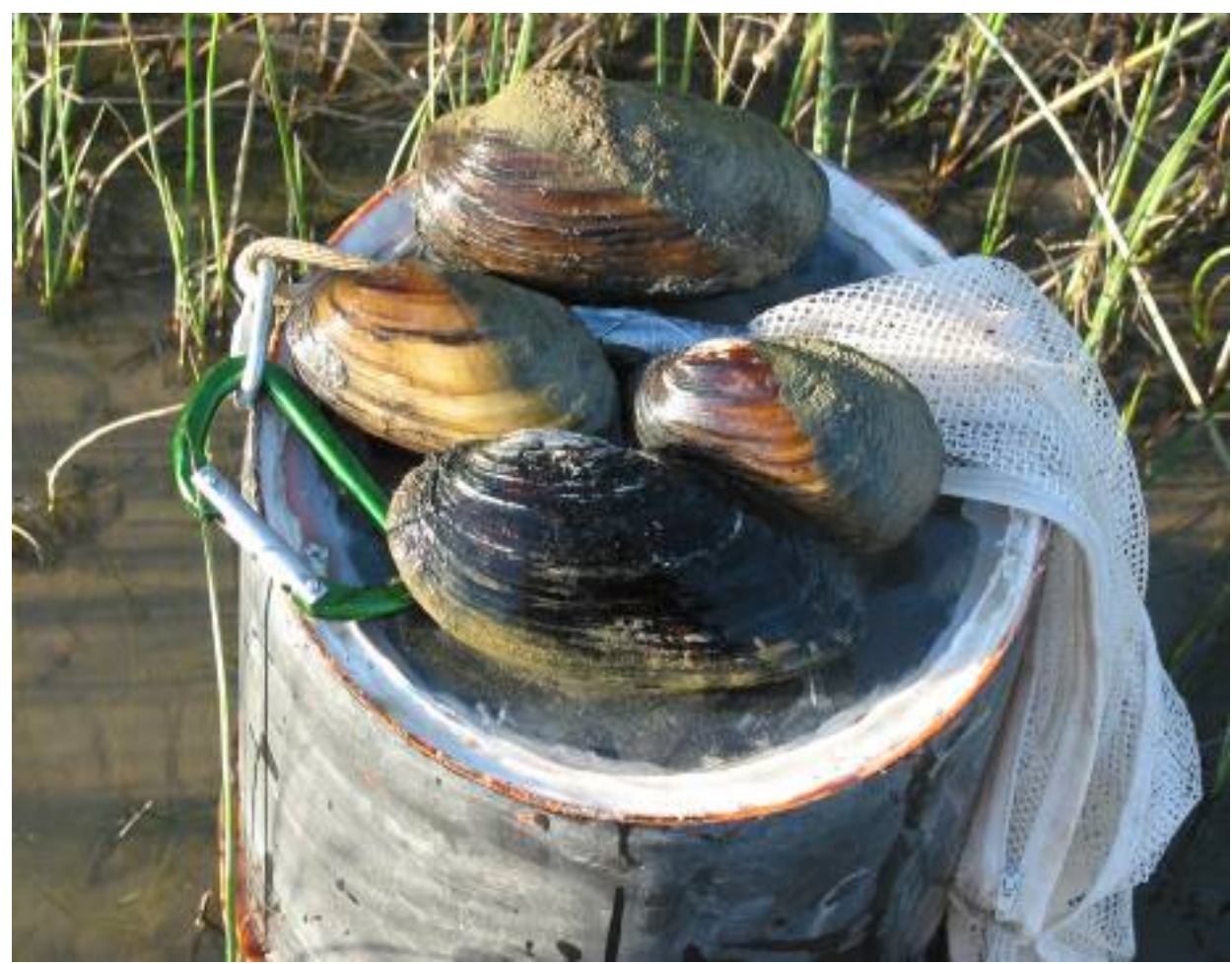

Prepared by

David Stagliano

Aquatic Ecologist

Montana Natural Heritage Program

1515 E. Sixth Ave

Helena, MT 59601

for

Montana Department of Fish, Wildlife and Parks

J une 2010 


\section{PREFACE}

The Mission of the Montana Natural Heritage Program (MNHP) is to serve as the state's most comprehensive source of scientific information used to manage Montana's native species and habitats, emphasizing species of conservation concern (SOC). Unfortunately, non-game species that are not listed or tracked by MNHP receive little attention or funding. Montana's Department of Fish, Wildlife \& Parks is mandated to manage aquatic invertebrates, including crayfish and mussels, but this is largely in the administrative sense. For example, the only mention of mussels on MTFWP's website is the threat of invading zebra mussels or in the fishing regulations handbook: "In accordance with the Administrative Rules of Montana, Section 12.2.501, it is unlawful to take or possess freshwater mussels or their shells for sale or commercial distribution”.

An agency tasked with comprehensive native species management should address all Montana's species, especially those (i.e. aquatic insects, mussels) with intricate ties to many freshwater game fish species. With the completion of MT's Comprehensive Fish \& Wildlife Conservation Strategy (CFWCS) for native species management in 2005, it became apparent that the invertebrate species of the state were lacking basic scientific information. The Western Pearlshell mussel (Margaritifera falcata) which was listed as a potential species of concern in 2004 (S2S24) (MNHP 2004) became a Tier I invertebrate species of greatest conservation need (CFWCS 2006), and the Mussel Taxonomic Group was in need of basic statewide inventory. In fact, little attention has been given to Montana's mussels since the Henderson reports of 1924 and 1936, but see cursory and regional treatments by Frest and Johannes1995 and McGuire and Marshall 2001. A statewide summary of mussel collections by Gangloff and Gustafson (2000) accomplished substantial gains in the knowledge of Montana's mussel fauna, but regardless of this recent work, an additional species was added to the faunal species list as recently as 2001 (Gustafson, pers. comm.). It was obvious that a more comprehensive treatment of the state's mussels would be needed. Therefore, MNHP solicited and received funds from State Wildlife Grants (SWG) to implement a comprehensive survey plan to determine distribution \& population viability of the 3 documented native mussel species, the western pearlshell (Margaritifera falcata), the fatmucket (Lampsilis siliquoidea) and the Giant floater (Pyganodon grandis), as well as the recently introduced species, the black sandshell (Ligumia recta), the mapleleaf (Quadrula quadrula) and the white heelsplitter (Lasmigona complanata). 


\section{EXECUTIVE SUMMARY}

During the past three years, we've made significant strides toward documenting distributions and understanding Montana's freshwater mussels through data compilation, inventory and public education. Although the five eastern Montana mussel species (2 native and 3 introduced) have secure populations and are even expanding their ranges, one of the state's native species, the western pearlshell, Margaritifera falcata has experienced significant range reductions in the past 100 years, and in 2008 was added to Montana's SOC list as a S2, vulnerable to extinction in the state. Despite finding eight western streams with large viable pearlshell populations (up to 3,000 mussels per $\mathrm{km}$ ), we have evidence from hundreds of negative surveys documenting the extirpation of the western pearlshell from countless streams and hundreds of river miles throughout the state, as well as dozens of non-viable populations that will be extirpated from streams and whole watersheds (Smith River) within the next 25 years. This fact should be an impetus to continue to research and understand this species in Montana, in addition to actively pursuing restoration projects that would benefit this species or its native fish host the westslope cutthroat trout.

We performed extensive surveys in most of the eastern watersheds of the state and report that the largest populations of warm water mussels, notably the native fatmucket and introduced black sandshell (avg. 8.2 and 4 mussels per hour, respectively), are found within the Wild \& Scenic Missouri River between Fort Benton and Judith River landing and the Marias River (above Lake Elwell \& within 10 miles of the confluence) where fatmucket populations are approaching those densities (avg. 7 per hr). The native giant floater is more evenly distributed and abundant in the Northern Glaciated Prairie River Basins compared to central and southeast Montana, but rarely did we find populations exceeding more than 10 mussels per hour. Our surveys in the Yellowstone River indicate that the mainstem river has much lower mussel density overall, with fatmucket catch rates averaging $~ 1$ per hour. Although, large prairie rivers entering the Yellowstone River have higher fatmucket densities: Bighorn and Tongue Rivers averaged 6 and 5 individuals per hour, respectively. We documented the first records of live giant floaters in the Yellowstone Basin at 3 tributary sites (O'Fallon, Little Porcupine, Tongue River), but no evidence of this species found live in the mainstem. The introduced mapleleaf (Quadrula quadrula) has high densities in the lower Tongue River, but was not found live in the mainstem Yellowstone. The introduced creek heelsplitter have increased their 
upstream distribution in the Milk River system, but not to the extent that the black sandshell have expanded their range.

The introduced mussels in Montana do not seem to be negatively affecting the native species, coexistence and non-exclusion is evident in stream reaches documented to have both present. But rather, they seem to be an augmentation to the mussel fauna of the state, and in the case of the black sandshell seems to be more viable in the upper Missouri River than in its native sections of the Missouri River where it is in decline.

Over the last three years we've given mussel survey and identification workshops to over 65 fisheries biologists and hydrologists in MT \& Idaho to increase the knowledge base, interest and capacity to survey and report mussel populations in all regions of the state. Attendees of these workshops reported back data for an additional 100 survey reaches, including the identification of two new viable western pearlshell sites in 2009. To generate public interest and support of freshwater mussels, we produced a pocket-sized mussel field guide and a full-sized Mussels of Montana Poster which will be distributed around the state from various agency offices and within the science educational system. Increasing interest and knowledge in freshwater mussels and species other than the typical sportfish is essential for the sustainability of these species and for the concern of the health of their aquatic ecosystems. 


\section{ACKNOWLEDGEMENTS}

I wish to thank Ken McDonald (MT FWP) who recognized the need to address non-game aquatic species and encouraged me in the early stages of my arriving at NHP to pursue this. Subsequently, T.O. Smith and Travis Horton (MT FWP) fostered this project through the comprehensive strategy and SWG Grants process. This project was funded through and supported by the Montana Fish Wildlife \& Parks State Wildlife Grants (SWG) program and the Natural Heritage Program (NHP) agreement \#080047. Thanks need to go to Dan Gustafson and Dan McGuire, who not only provided valuable data, photographs and discussion, but whose knowledge of Montana’s invertebrates vastly made my job easier starting off on my invertebrate endeavors for the state. Present and previous Heritage Program zoologists who chose to address rare invertebrates when no one else would (D. Genter and P. Hendricks), and those who assisted in my mussel collection efforts: S. Lenard, C. Currier, L.Wilson, J. Clarke, and E. Colaiacomo, also need to be thanked. For collecting additional mussel data or visiting and reporting new sites, I thank S. Barndt, D. Downing, B. Gardner, S. Gerdes, P. Hutchinson, J. Hansen, P. Hopper, M. Jakober, J. Lindstrom, R. Pierce, P. Price, B. Riggers, S. Spaulding and their crews. Scott Blum (MTNHP) reviewed and appended data into the state-wide Point Observation Database (POD) and Meghan Burns (MTNHP) produced most of the maps in this report. This report was improved greatly by editing from Bryce Maxell and Linda Vance. 


\section{Table of Contents}

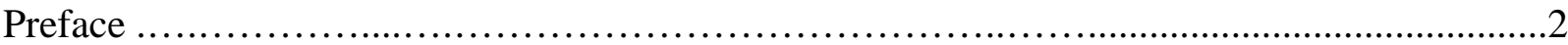

Executive Summary .................................................................

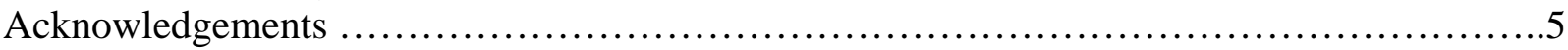

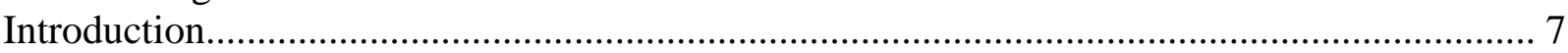

Systematic List of Montana Mussels............................................................................12

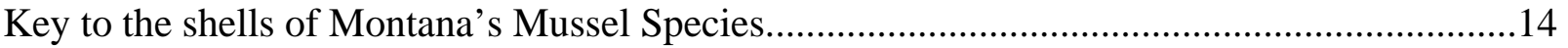

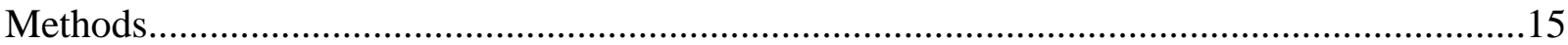

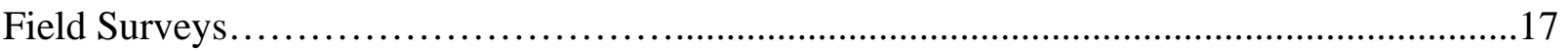

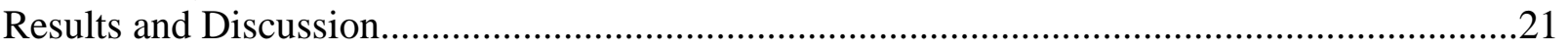

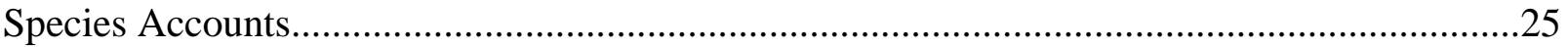

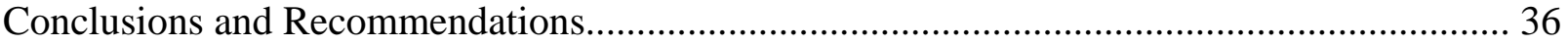

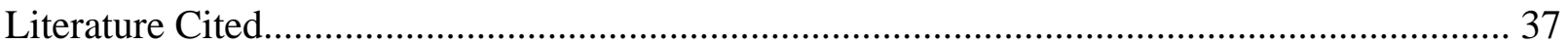

Appendix A. Global/State Rank Definitions

Appendix B. Mussel Survey Sites by Watershed

Appendix C. Western Pearlshell Mussel Viability Sites

\section{List of Tables}

Table 1. Status, distribution and fish hosts of mussel species that occur in Montana.............. 13

\section{List of Figures}

Figure 1. Generalized Mussel Life Cycle (courtesy of USFWS)...........................................8

Figure 2. Four basic life stages of freshwater mussels and possible limiting factors.............9

Figure 3. The longitudinal transect mussel survey technique with an aquascope....................17

Figure 4. The longitudinal transect mussel survey technique using SCUBA.....................17

Figure 5. Quantitative Search for juveniles using $0.25 \mathrm{~m}^{2}$ quadrat ............................19

Figure 6. Number of live mussel individuals per survey site in Montana and Idaho............20

\section{List of Maps}

Map 1. Targeted $5^{\text {th }}$ code Watersheds for SWG Mussel Sampling............................. 12

Map 2. Distribution of mussels in Montana based on surveyed sites and literature records......22

Map 3. Watershed distribution of mussels in Montana based on positive survey points within the $5^{\text {th }}$ code HUCs............................................................23

Map 4. Distribution of the Western Pearlshell in Montana based on positive survey points......27

Map 5. Viability of Western Pearlshell populations in Montana and Idaho based on positive

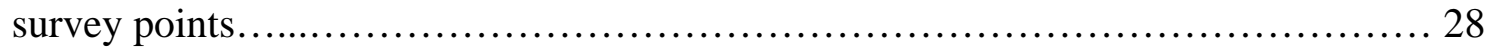

Map 6. Distribution of the Fatmucket in Montana based on positive survey points.............29

Map 7. Distribution of the Giant Floater in Montana based on positive survey points...........32

Map 8. Distribution of the Black Sandshell in Montana based on positive survey points........34

Map 9. Distribution of the White Heelsplitter in Montana based on positive survey points.....36

Map 10. Distribution of the Mapleleaf in Montana based on positive survey points.............37 


\section{INTRODUCTION}

The world's greatest diversity of freshwater mussels (Unionoida) is concentrated in North America, with approximately 300 species and subspecies (Turgeon et al. 1998; Stein et al. 2000). The southeastern United States is the continental hotspot with 269 of these species (Stein et al. 2000), and mussel diversity decreases significantly the further north and west one travels from this region. Unfortunately for states such as Montana, Wyoming and Colorado which straddle the continental divide and sit at the headwaters of major rivers, mussel species diversity also decreases as one ascends the watershed, coinciding with decreasing fish diversity (Watters 1992). Thus, the resultant low native mussel diversity in Montana (three, maybe four species historically; Henderson 1924) has translated into little interest or attention to our mussel fauna (Gangloff and Gustafson 2000). Adjacent western states have similar low mussel diversity: Wyoming has seven species (Cvancara 2005), Colorado had seven species (only three are extant) (Cordeiro 1999) and Idaho reported five mussel species (Frest and Johannes 2000), but one undescribed species has been synonomyzed resulting in four total native species. In accordance, downstream Missouri River state’s mussel faunas increase in richness with North Dakota having 13 species (Cvancara 2000) and South Dakota harboring 28 species.

Most of the freshwater mussels (Bivalvia: Unionida) that occur in North America belong to the family, Unionidae; only five species are in the family Margaritiferidae, one of which occurs in Montana. Freshwater bivalves are truly ancient invertebrates, dating back to the late Devonian Period (Grayson 1988). We consistently find mussel shells embedded in eroded sandstone outcrops in eastern Montana dating back to the Paleocene ( 50mya) (Stagliano, pers. obs.), and two extant species in Montana were uncovered from a prehistoric mine site near Three Forks dating back 2-3 thousand years (Lippincott and Davis 2000). The western pearlshell, Margaritifera falcata mussel probably arrived in Montana's upper Missouri River Basin >5 mya from migrating westslope cutthroat trout when the upper Missouri River from Canyon Ferry Reservoir flowed south to the Snake River (Gustafson 2000). The presence of M. falcata in Montana has been referred to since 1869 (Cooper 1869); though Lewis and Clark must have encountered evidence of this mussel, but did not mention this species. They did name the Musselshell River on their way up the Missouri River in May 1805 due to the numerous mussel shells found on the banks (Jackson 1962); these were presumably fatmuckets.

Unfortunately, the rich historic mussel fauna of North America has recently become seriously jeopardized. During the past century, North American freshwater mussels have 
undergone drastic declines, and they currently are one of the most imperiled groups of animals on the planet (Williams et al. 1993) and especially in North America (Allen and Flecker 1993, Stein et al. 2000) where of the approximate 300 native species, nearly two-thirds are considered to be in need of some conservation attention (Williams et al. 1993); 61 of these species are federally listed as endangered and eight listed as threatened (USFWS Box Score, 2003). Thirty-six species are believed to have gone extinct in North America and that number is expected to rise (Neves et al., 1997; Bogan 1993).

Reasons for protecting the state's freshwater mussels are numerous. Because mussels are filter feeders, they contribute greatly to water quality by removing suspended particles of sediment and detritus. According to Allen (1914), an average-sized mussel can filter over eight gallons of water during a 4 hour period. In high-density mussel beds, the filtering effect of thousands of mussels can be ecologically significant.

Another important ecological contribution of mussels includes being an important food source for aquatic and terrestrial animals. Furbearers such as the raccoon, muskrat, and otter utilize mussels extensively as food. Although only a few fishes extensively utilize mussels directly as food (freshwater drum and carp), many other species benefit because filter-feeding mussels discard undigested food in strands of mucus, called pseudofeces. This material is fed upon by other stream invertebrates that are, in turn, fed upon by fishes. Mussels basically convert inaccessible sestonic drifting nutrients and carbon into a benthic food source.

The life history of

freshwater mussels consists of four basic life stages: reproductive, larval or parasitic, juvenile, and adult (Figure 1). The larval stage (glochidium) must briefly parasitize a vertebrate host (usually a fish) in order to complete its development (see Table 1 for a list of fish hosts for mussels in

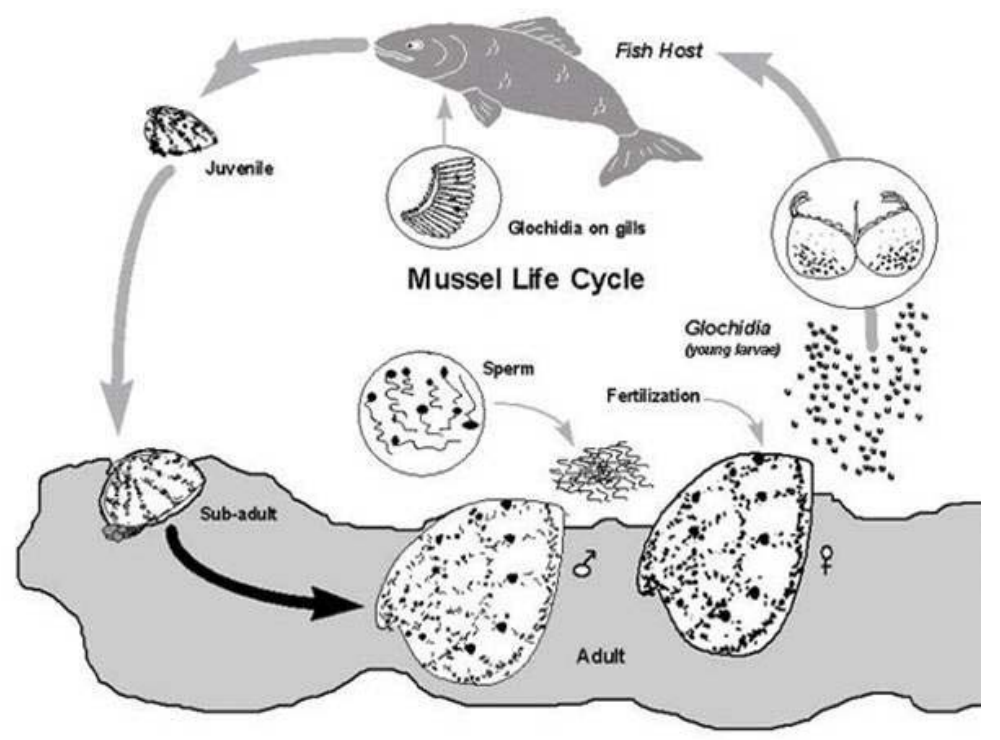
Montana). These glochidia must attach to the gills of a fish within a few days in order to survive. They eventually fall off of the 
host as a small juvenile mussel. The primary function of larval parasitism on fish appears to be transport to upstream habitats (Surber 1913), since unattached larvae can only drift downstream and adult mussels are not very mobile; although, a small nutrient meal is also gained by the larvae. Both of these events exhibit high mortalities, which are offset by long-lived adults and a release of huge numbers (millions) of glochidia.

Many mussel species have fascinating reproductive adaptations to increase the chances that glochidia will make contact with a suitable fish host (Barnhart et al. 2008). Numerous articles, pictures and videos exist that describe and show the evolutionary phenomenon of female mussel lures (fish or invertebrate prey items) used to dupe fish into coming within range or biting the lure to become infested with the glochidia or larval mussels (Haag and Warren1999). Mussels are often labeled as "generalists" or "specialists" with regard to the variety of fish they will use as hosts. Most of the species in Montana are generalists using multiple species of host fish; the western pearlshell is perhaps the most specialized evolving with westslope cutthroat trout and has a host preference to salmonids of the genus Oncorhynchus (Table 1).

Reproduction among host specialists relies on the distribution, densities and dynamics of its specific host fish, adding uncertainty to an already tenuous reproductive strategy.

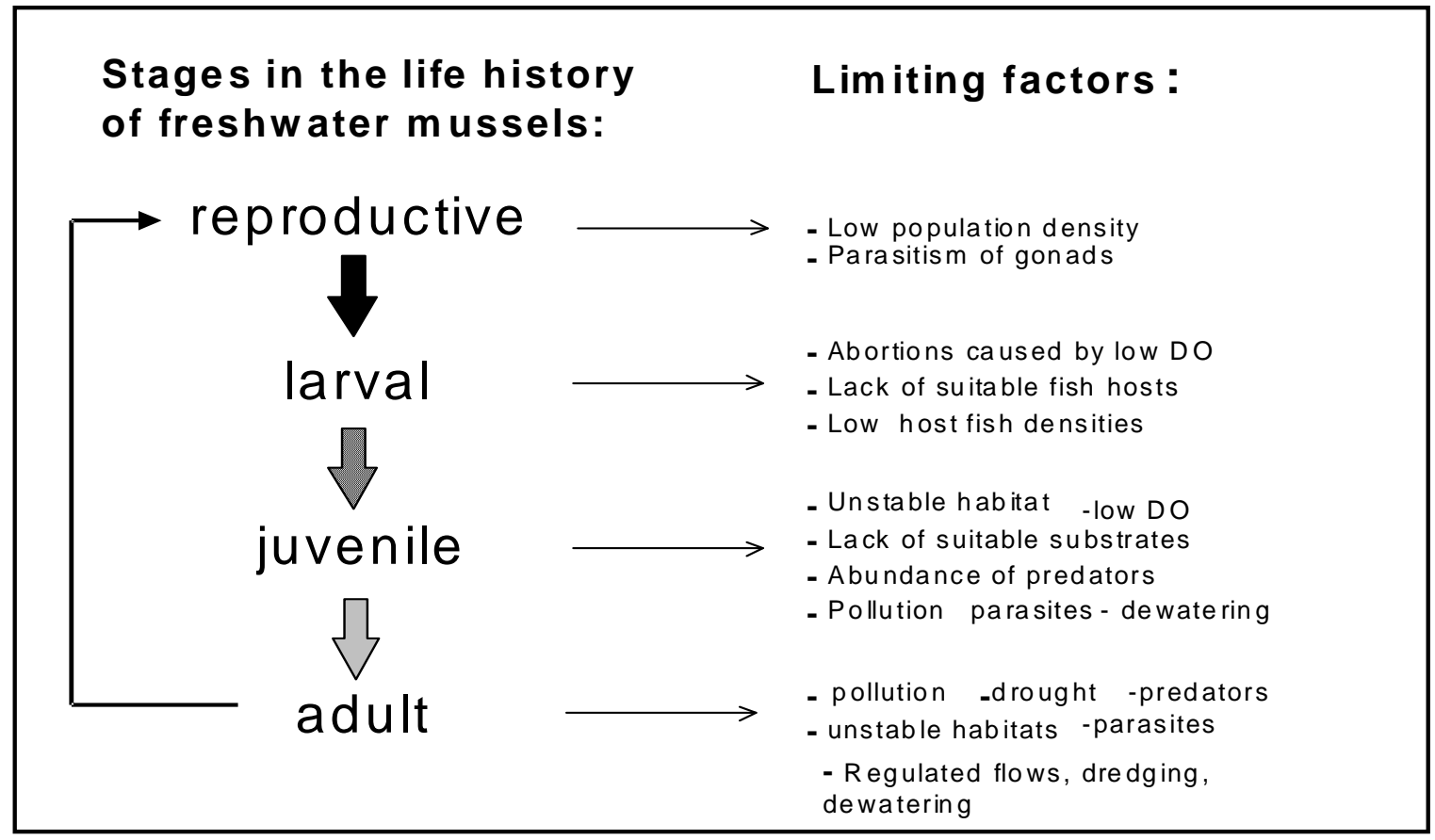

FIGURE 2. Four basic life stages of freshwater mussels and possible limiting factors. 


\section{Ecological Requirements}

Habitat. Characterization of specific habitat requirements for freshwater mussels is difficult because of the broad microhabitat tolerances and site-specific preferences (Strayer 1981; Gordon and Layzer 1989; Strayer and Ralley 1993). Habitat use on a broader scale, however, is more predictable. For instance, the western pearlshell prefers stable gravels and pebbles in small to medium coldwater rivers with Rosgen C channel morphology (Rosgen 1996) or predominately the C007 Aquatic Ecological System (Stagliano 2005). While the mussels that occur in eastern Montana are generally found in medium to large warm-water prairie streams at depths less than a couple of meters in predominantly gravel, sand or silted substrates, which are stable and well compacted, not loose and shifting. Although in the Wild and Scenic Section of the Missouri River, the black sandshell has been observed in higher velocity, cobble substrate areas than any of the other species (Stagliano, personal observation). The giant floater, Pyganodon grandis, is the native species found in the smallest prairie streams and tolerates the most lentic conditions and the softest sediments (silted side channels) (see Species Accounts for more detailed habitat information).

\section{Causes for the Decline}

There are many potential causes for the decline of all life history stages of mussels in Montana and across North America (Figure 2). Factors such as stream habitat degradation and fragmentation (e.g., dams, stream channelization, diversions and dredging), host fish declines and point and nonpoint source pollution are implicated in mussel declines throughout North America (Bogan, 1993; Neves et al., 1997). These factors may affect all four life stages of a species or may be especially detrimental to a particular life phase (Figure 2). Dewatering of stream channels is an almost instant way to kill adult and juvenile mussels in the benthic substrate. More recently, the nonindigenous, zebra mussel (Dreissena polymorpha), because of its high reproductive capability and competitive interaction with native mussels, has begun to wreck havoc on mussel populations in eastern and mid-western states as close as South Dakota.

The main cause of stream deterioration in Montana is high sediment load, chiefly related to agricultural practices, which is considered the most serious pollutant of North American streams (Waters 1995), and is the most listed cause of stream impairment on Montana’s 303(d) waterbody list (MTDEQ 2007). Anthropogenic sediment can degrade mussel habitats by embedding the substrate, which decreases substrate permeability. Because 
juvenile mussels are restricted to primarily interstitial habitats, the smothering effect of silt is probably a major factor in preventing successful recruitment for sensitive species (Marking et. al. 1979). Additionally, as sediment restricts the spawning success of certain mussels' salmonid host species, lowered fingerling densities in stream sections inhabited by mussels becomes a recruitment limitation (Bogan1993).

Anthropogenic habitat modifications can also lead to widespread declines in mussel diversity and abundance (Williams et al. 1993; Bogan 1993; Layzer and Madison 1995). When a river or stream is dammed, the impounded stream channel is transformed from a free-flowing, well-oxygenated environment to one that is stagnant and prone to silt deposition, which is intolerable for most riverine species. The presence of multiple large dams and reservoirs in eastern Montana (Fort Peck, Tiber, Fresno, Yellowtail, Tongue River and numerous smaller ones, like Beaver Creek and Whitetail Reservoir, has caused the loss of hundreds of cumulative miles of warm water riverine mussel habitat, but in turn has expanded habitat for the giant floater in the northern glaciated region which can tolerate lentic (lake-type) conditions. The suitability of below-reservoir downstream habitats for mussels is also influenced by the operation of dams. Cold water discharges from the bottoms of larger dams in eastern MT create unsuitable temperature regimes and substrate conditions for many miles below. For instance, in the Marias River, it is at least 10 river miles below Tiber dam before prairie river characteristics return making it suitable for warm water mussels, and closer to 20 miles downstream before populations of the fatmuckets are similar to those above the reservoir (Stagliano, unpublished). Dams serve as barriers to host fish, preventing upstream and downstream recolonization or migration. Because of this strong mussel-fish interdependence, any threat to host fish also jeopardizes mussel survival. If suitable host fish disappear, due to fish community changes, fish corridor blockages (dams\& diversions) or water pollution, mussel populations will not be viable in the long term (Bogan 1993).

\section{Conservation}

Perhaps the most fundamental reason for protecting any species is the concept of stewardship. This concept holds that, apart from any perceived utility or profit in a species, man has the moral obligation to protect and preserve the diversity of the natural world, lest we live in a monoculture. Each species is an irreplaceable part of our natural heritage. 


\section{"To keep every $\operatorname{cog}$ and wheel is the first precaution of intelligent tinkering."}

—Aldo Leopold, Sand County Almanac

Ecosystem-based conservation, where the contribution of all species in maintaining ecological processes is considered-is coming to the forefront, replacing the previous focus on just a few conspicuous species, mostly "cute and fuzzy" vertebrates and plants. The public is also developing an appreciation for at least some groups of invertebrates. Mussel shells are collected by amateur and professional biologists, who find them to be both interesting and educational. The shells provide a durable record of a species presence. They also provide a record of the history of each individual in the annual rings of growth, which show that some species live over a century. This record can also document changes in stream health through time because mussels are long-lived and sensitive to pollution. Therefore, mussels serve as important indicators of aquatic health.

Three species of native and three introduced freshwater mussels (Order: Unionoida, Families: Unionidae and Margaritiferidae) are documented to occur in Montana (see Table 1): the Western Pearlshell (Margaritifera flacata); the Fatmucket (Lampsilis siliquoidaea) and the Giant floater (Pyganodon grandis) are native; while the Black Sandshell (Ligumia recta), the Mapleleaf (Quadrula quadrula) and White or Creek heelsplitter (Lasmigona complanata) are introduced. It is possible that Little Missouri River populations of the heelsplitter are native.

\section{SYSTEMATIC LIST OF MONTANA MUSSELS}

Phylum Mollusca

Class Bivalvia

Order Unionoida

Family Margaritiferidae

1. Western pearlshell Margaritifera falcata (Gould, 1850)

Family Unionidae

2. Fatmucket Lampsilis siliquoidea (Barnes, 1823)

3. Giant floater Pyganodon grandis (Say, 1829)

4. White heelsplitter Lasmigona complanata (Barnes, 1823)

5. Black sandshell Ligumia recta (Lamarck, 1819)

6. Mapleleaf Quadrula quadrula (Rafinesque, 1820) 
TABLE 1. Status, distribution and fish hosts of mussel species that presently occur in Montana.

\begin{tabular}{|c|c|c|c|c|}
\hline Species & Status & $\begin{array}{l}\text { Aquatic } \\
\text { System }^{\text {a }}\end{array}$ & $\begin{array}{l}\text { MT Range, } \\
\text { Basin b }\end{array}$ & Fish Hosts in Montana \\
\hline $\begin{array}{c}\text { Western Pearlshell } \\
\text { (Margaritifera falcata) }\end{array}$ & $\begin{array}{l}\text { G4 S2 SOC } \\
\text { At-Risk }\end{array}$ & 1 & $\begin{array}{l}\text { Sporadic, formerly } \\
\text { ubiquitous in } \\
\text { western MT } \\
\text { streams: KT, CF, } \\
\text { BL, UMO }\end{array}$ & $\begin{array}{c}\text { Salmonids of Oncorhynchus genus } \\
\text { (Westslope Cutthroat, Rainbow } \\
\text { Trout) \& Salvelinus (Brook, Bull } \\
\text { Trout) }\end{array}$ \\
\hline $\begin{array}{c}\text { Giant floater } \\
\text { (Pyganodon grandis) }\end{array}$ & $\begin{array}{l}\text { G5 S4 } \\
\text { Secure }\end{array}$ & $2 \& 3$ & $\begin{array}{l}\text { Eastern MT , MO, } \\
\text { MU, MI, YE }\end{array}$ & $\begin{array}{l}\text { Native species: Iowa darter, brook } \\
\text { stickleback, channel catfish } \\
\text { Introduced: carp, bullheads, } \\
\text { centrarchids and yellow perch }\end{array}$ \\
\hline $\begin{array}{l}\text { Fatmucket } \\
\text { (Lampsilis } \\
\text { siliquoidaea) }\end{array}$ & $\begin{array}{l}\text { G5 S5 } \\
\text { Secure }\end{array}$ & $2 \& 3$ & $\begin{array}{l}\text { Eastern MT , MO, } \\
\text { MU, MI, YE }\end{array}$ & $\begin{array}{l}\text { Native species: freshwater drum, } \\
\text { channel catfish, stonecat, sturgeons } \\
\text { Introduced: carp, bullheads, } \\
\text { centrarchids and yellow perch }\end{array}$ \\
\hline $\begin{array}{l}\text { Black Sandshell } \\
\text { (Ligumia recta) }\end{array}$ & $\begin{array}{l}\text { G5 SNA } \\
\text { Introduced, } \\
\text { expanding }\end{array}$ & 2 & $\begin{array}{c}\text { Eastern MT, MO, } \\
\text { MU, MI }\end{array}$ & $\begin{array}{l}\text { Native species: Sauger } \\
\text { Introduced Species: Walleye, } \\
\text { Yellow Perch, Centrachids }\end{array}$ \\
\hline $\begin{array}{l}\text { White heelsplitter } \\
\text { (Lasmigona } \\
\text { complanata) }\end{array}$ & $\begin{array}{l}\text { G5 SNA } \\
\text { Introduced, } \\
\text { isolated } \\
\text { populations }\end{array}$ & 2 & $\begin{array}{l}\text { Lower MI, Beaver } \\
\text { Creek trib. to the } \\
\text { Little MO }\end{array}$ & $\begin{array}{l}\text { Native species: None. } \\
\text { Introduced Species: Common Carp, } \\
\text { Green Sunfish, Largemouth Bass }\end{array}$ \\
\hline $\begin{array}{c}\text { Mapleleaf } \\
\text { (Quadrula quadrula) }\end{array}$ & $\begin{array}{l}\text { G5 SNA } \\
\text { Recently } \\
\text { introduced, } \\
\text { isolated } \\
\text { populations }\end{array}$ & 2 & $\begin{array}{l}\text { Tongue River, } \\
\text { Lower Yellowstone }\end{array}$ & $\begin{array}{l}\text { Native species: Channel Catfish } \\
\text { Introduced Ictalurids: Bullheads, }\end{array}$ \\
\hline
\end{tabular}

${ }^{\text {a } 1-~ M o u n t a i n ~ S t r e a m s ~ \& ~ I n t e r m o n t a n e ~ R i v e r s ~ c a p a b l e ~ o f ~ s u s t a i n i n g ~ s a l m o n i d ~ p o p u l a t i o n s . ~ 2-M e d i u m-l a r g e ~}$ mixed-river systems \& prairie rivers. 3-prairie streams

${ }^{\mathbf{b}}$ MO- Missouri River below Great Falls, MI-Milk River, MU-Musselshell River, YE-Yellowstone River, KTKootenai River, CF- Clark Fork, BL- Blackfoot R., UMO-Upper Missouri River above Great Falls 
Key to the shells of Montana's Mussel Species:

1. Hinge without teeth, shell light-weight (Native) .(Giant Floater) Pyganodon grandis (Say)

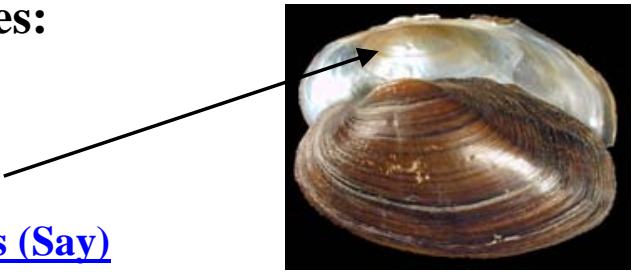

1'. Hinge with teeth, shell heavier.

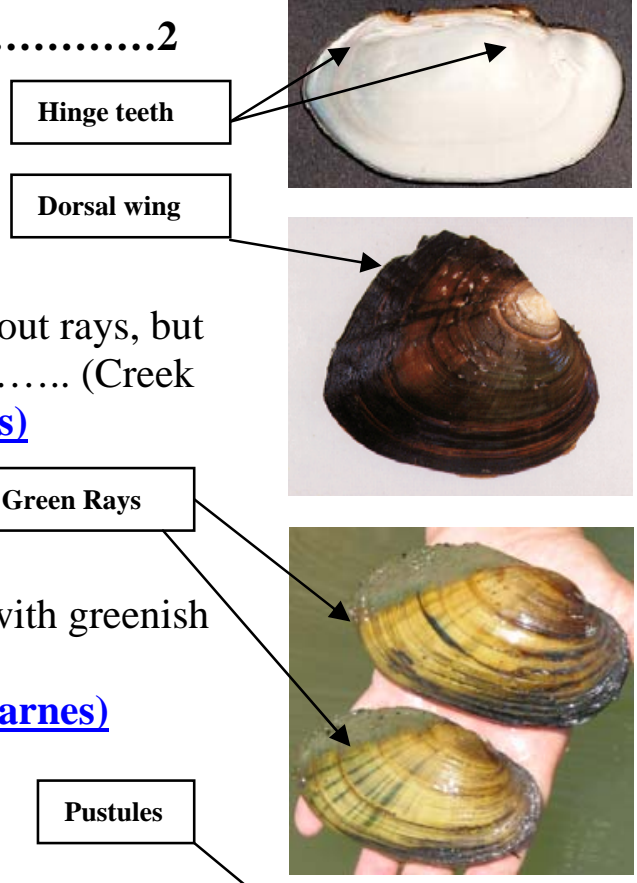

2b. Outside of shell light brown to tan, often with greenish rays \& without a dorsal wing (Native).......

2a. Outside of shell dark brown to black, without rays, but with a dorsal wing (Introduced). (Creek Heelsplitter) Lasmigona complanata (Barnes) ..........(Fatmucket) Lampsilis siliquoidea (Barnes) but with radiating rows of pustules or ridges (Introduced) ........(Mapleleaf) Quadrula quadrula (Rafinesque)

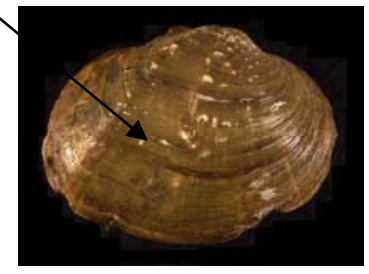

2’. Inside of shell purple or pink .3

3. Ventral edge slightly concave, shell and teeth weak (Native) (Western Pearlshell) Margaritifera falcata (Gould)

3'. Ventral edge convex, shell heavy and teeth strong (Introduced) (Black Sandshell) .Ligumia recta (Lamarck)
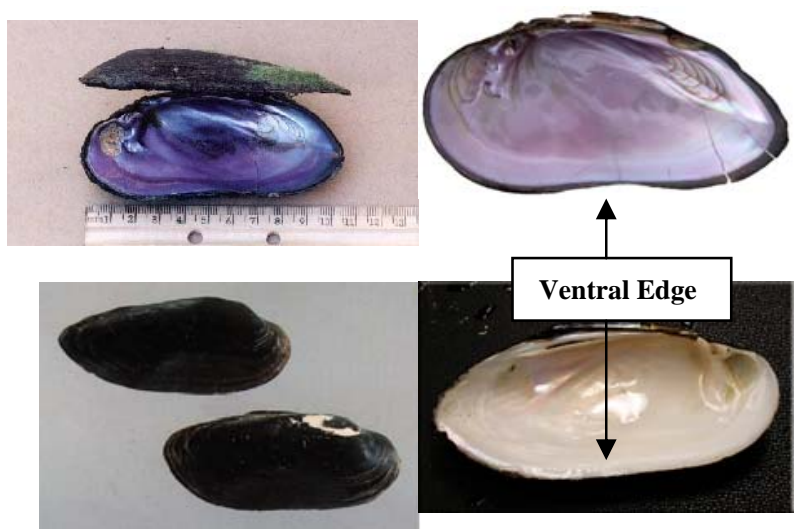


\section{METHODS}

\section{Data Compilation}

Data compiled and collected for this project came from numerous sources and locations:

1) historical and museum records from previous mussel collections in the state dating back to Cooper (1869), Elrod $(1900,1902)$ and Henderson $(1924,1936)$

2) more recent targeted mussel collection records made available for NHP use (D. Gustafson, D. McGuire), some of which have been previously published in Gangloff and Gustafson (2000), McGuire and Marshall (2001).

3) Incidental mussel shells reported by various agency biologists during stream fisheries projects or general public sightings

4) NHP and USFS standardized mussel collections using methodology described below. The last collection method is the only data which we converted to mussel catch per unit effort or used to estimate population viability ranks (A-D, NatureServe 2008).

\section{Museum Collections}

We supplemented our sampling and literature review work with online database and/or requested searches of collection records held at various institutions known as mollusk repositories (Ohio State University, University of Michigan Museum of Zoology, California Academy of Sciences, National Academy of Sciences in Philadelphia, Illinois Natural History Survey), as well as personal collections made by D. Gustafson and D. McGuire. From these museum searches, we obtained very few records of mussels from Montana, this effort confirmed how understudied this state's mussel fauna truly is. Voucher specimens from our work have been deposited at the Montana Natural Heritage lab in Helena and at the University of Alabama Collections. Identifications followed Burch (1989) and were confirmed by Dan Graf (University of Alabama, previously with the Philadelphia Academy of Sciences), nomenclature follows Turgeon et al. (1998).

\section{Statewide Watershed Sampling Design}

Montana is a geographically huge and diverse state and the prospect of a statewide sampling scheme was a daunting task; therefore we delineated priority watersheds "somewhat randomly" based on a number of criteria. First priority was given to watersheds having previously 
reported mussels or historical records; second, watersheds identified as Tier I or II priorities in the Comprehensive Fish \& Wildlife Conservation Strategy (CFWCS 2005) and third, where there were concurrent MNHP projects occurring in the region that would allow multiple site visits at a lower cost to the project. We developed a sampling scheme that allowed statewide coverage ( $>50 \%$ of all $5^{\text {th }}$ code watersheds visited), in addition to targeting $90 \%$ of the Tier I or II priority watersheds (Map 1). Non-priority watersheds were opportunistically surveyed throughout the study. No effort was made to sample ponds/lakes or wetlands in the priority watersheds.

\section{Map 1. Targeted $5^{\text {th }}$ code Watersheds for SWG Mussel Sampling.}

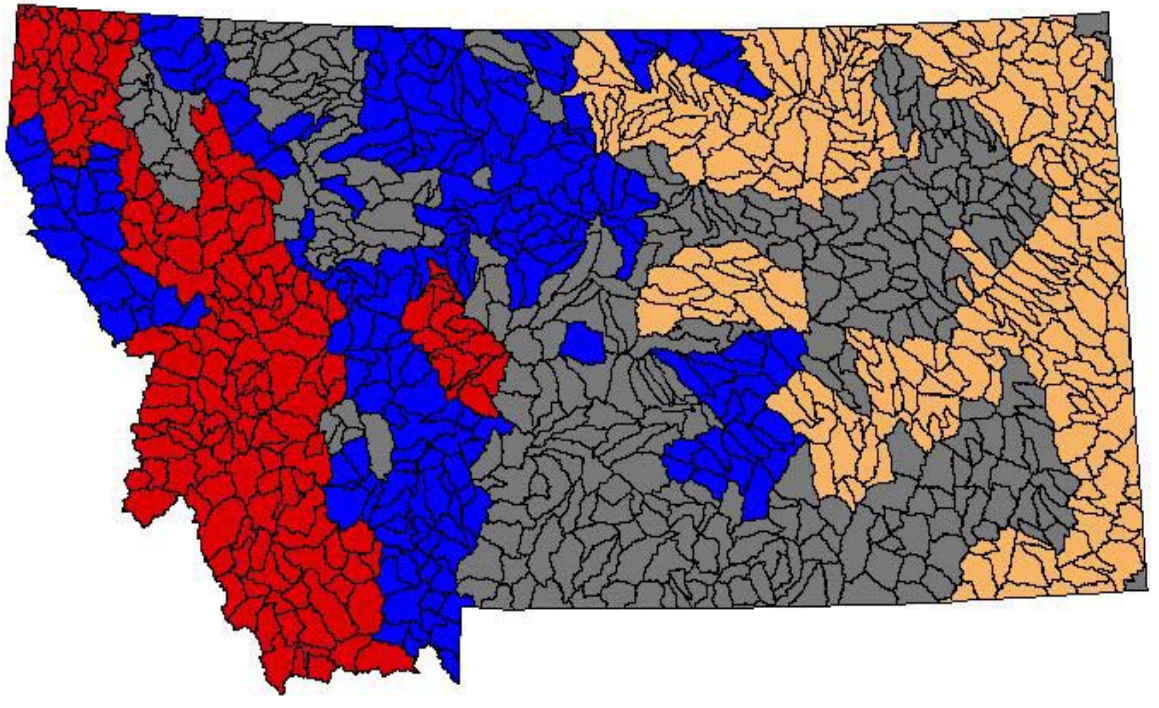

Survey Priorities

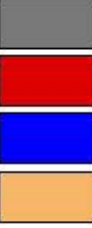
not targeted 2007 2008 2009

\section{Mussel Field Sampling}

Mussels were sampled using a catch-per-unit-effort (CPUE) or catch per linear distance (CPUD) approach because the emphasis of our study is to determine species composition (presence/absence) and relative abundance and not to quantify densities (Vaughn et al. 1996). Time searched by the number of surveyors is expressed as number of mussels per person-hour and a measured stream distance traveled was converted to mussels per linear meter of stream (mussels per 50 stream meters). We usually devoted at least 1 man-hour of search per site and an effort was made to sample multiple geomorphic units (riffle, glide and pool sequences) and all available habitats therein. The amount of effort was dependent upon the amount of mussel evidence (shells or fragments seen), suitable habitat conditions and stream substrate (ease of sampling greatly increases the stream distance sampled). CPUE techniques provide a more 
complete look at the mussel assemblage than substrate excavation quadrat methods, and are more likely to locate rare mussels (Kovalak et al. 1986) or those with low densities (Payne et al. 1997, Vaughn et al. 1996). Visual surveys were conducted along a series of 50m transects searched along the longitudinal length of the stream, depending on habitat complexity (Young et al. 2001). The longitudinal transect survey technique with additional side searching enables two surveyors to effectively search an entire cross-section of the stream channel less than $\sim 6 \mathrm{~m}$ wetted width (ww) (Figure 3). In wider streams, surveyors are positioned on each side of the stream searching the likeliest habitats paralleling each other, while in smaller channels $(<4 \mathrm{~m}$ WW) a single surveyor can cover the entire channel and the $2^{\text {nd }}$ surveyor can proceed upstream a certain distance to begin another section of stream reach, usually at least 50m upstream to prevent substrate disturbance from clouding the water for surveyor \#1; this leap-frog style of survey can quickly cover multiple 50m segments of the stream. This procedure begins at the most downstream transect in the reach.

Aquascopes (glass bottomed buckets) were used for underwater viewing within $1 \mathrm{~m}$ on each side of the transect while wading, or in depths $>0.5 \mathrm{~m}$, SCUBA or snorkeling was used along transects (Figure 4). We obtained global positioning system coordinates (GPS) at the downstream end of the reach for each site using a Garmin GPS 76 MAP (Garmin International) and surveyed in an upstream

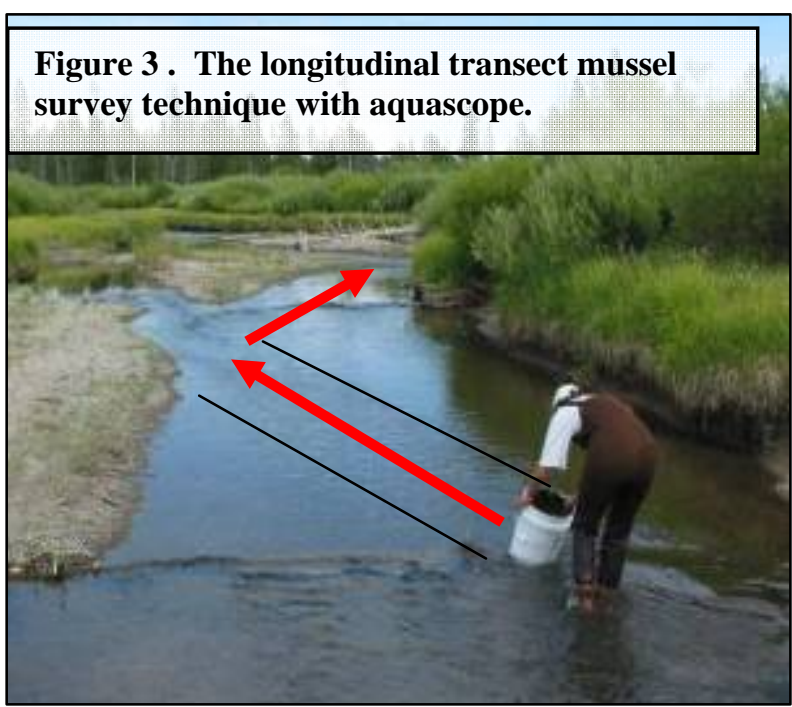

Figure 4. The longitudinal transect mussel survey technique using SCUBA.

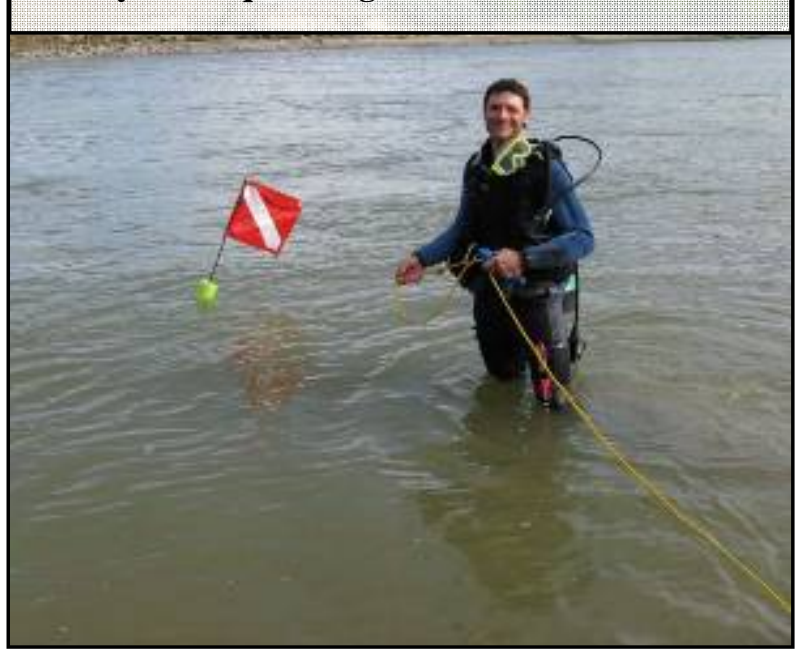
direction marking the end of the reach with another GPS point. Visual surveys tend to be biased toward larger individuals, but by remaining consistent across all stream reaches, the data collected is expected to be comparable across sites and watersheds. 
Mussels (and dead valves) observed during the timed-transect period were placed in mesh bags for processing at the end of a 50m segment or if populations were sparse then data were recorded immediately. Live individuals collected were identified to species, measured within $5 \mathrm{~mm}$ size-classes, enumerated and returned to where they were taken from the substrate. Dead valves were taken back as a collection record to be deposited at the Montana Natural Heritage Program, Montana State University and other mollusk repositories. Dead valves were included in the survey data only if live individuals of that species are not found. Dead valves can provide substantial information about populations by designating fresh dead (within days), recent (within 1 year) or relics (older than 1 year), as well as the size range of shells.

No effort was made to sample ponds/lakes or wetlands in the watersheds, but lentic mussel presence sites reported to NHP were included in the database.

The simplest type of field data collected is the presence of a species at a particular location, but this basic information provides little or no information about the health of a population. We performed surveys in a manner that allows qualitative population estimates and sustainability of populations in an effort to document long term species viability at surveyed sites (see Viable Mussel Populations; NatureServe 2008, Strayer and Smith 2003).

Age or size structure data can reveal characteristics of the population such as poor recruitment (if no young or small mussels are present), low adult survival (if no older animals are present), or a population is dominated by individuals of a certain age (Miller and Payne 1988). Aging mussels can be difficult and expensive to determine (methods reviewed in Nedeau et al. 2000), but the size distribution of animals, determined by measuring each animal encountered, can provide a suitable alternative to age data. Once mussel beds are found, a quantitative method for estimating densities and locating juveniles is excavating a series of $0.25 \mathrm{~m}^{2}$ quadrats (Figure 5). Oftentimes young mussels $(<30 \mathrm{~mm}$ ) will not be visible on the surface. Only by digging out the substrate within the $1 / 4 \mathrm{~m}^{2}$ quadrat by hand or rake down to the streambed and sifting sediments through a sieve or mesh net will one locate these and document successful recruitment. We used these quantitative methods on a subset of streams (i.e., those with a fair abundance of $M$. falcata) to determine the presence of juvenile mussels. Additionally, determining numbers of buried mussels in relation to those on the surface can double density estimates in deep gravel, dense mussel beds. Data recorded: Number juvenile mussels $\mathrm{m}^{-2}$ in the mussel bed and the B-Factor = \# Buried / \# Visable in the Quadrats. 


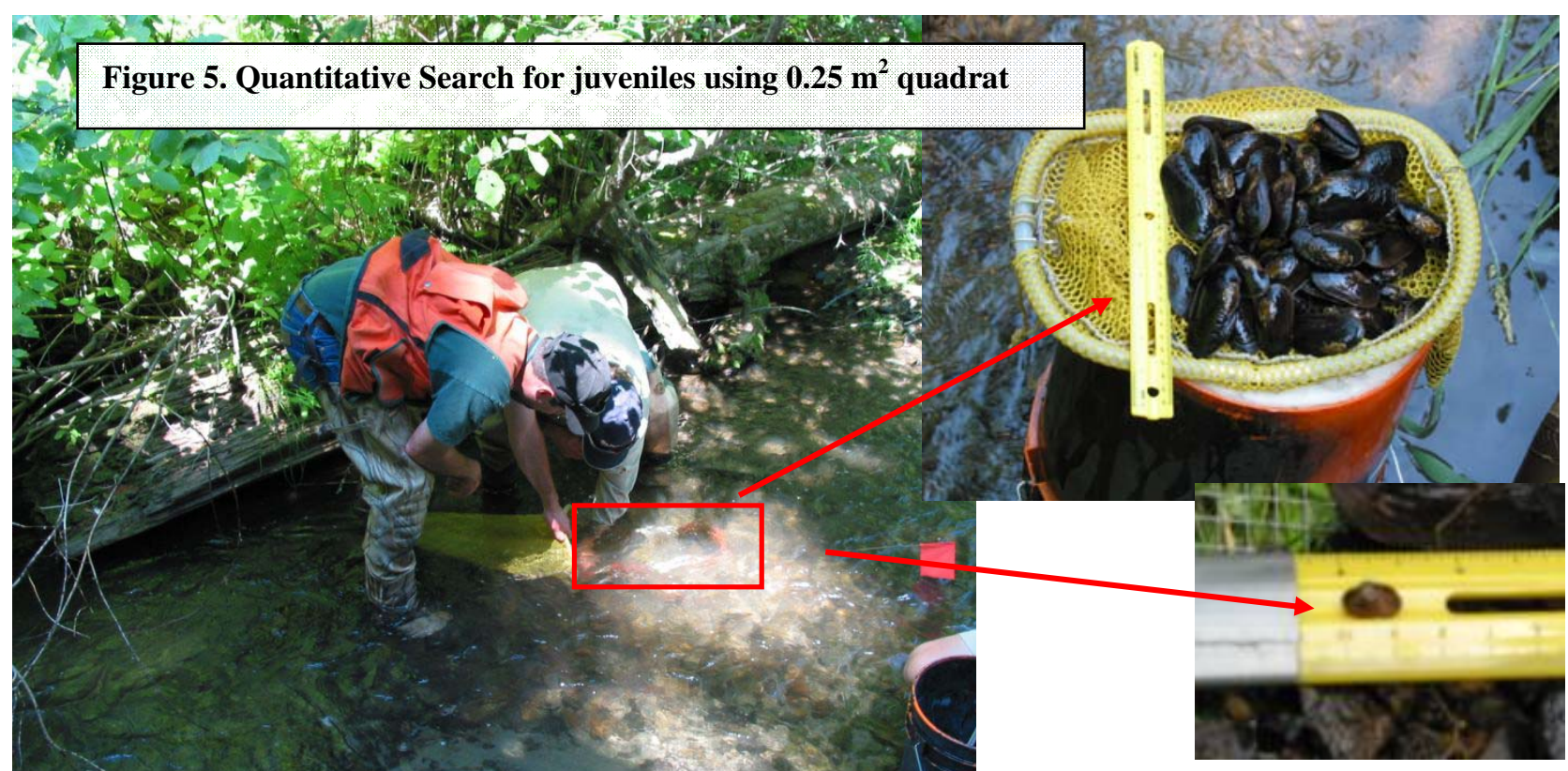

High population density may indicate a healthy and stable population whereas low population density may be cause for concern. Combined with age or size data, population density can be used qualitatively. The condition of individual animals, such as the degree of shell erosion or deformities can provide insight into longevity of individuals and the severity of the ambient water quality conditions.

\section{Characteristics of Viable Mussel Populations}

Using characteristics of the population data collected at the site, we applied the following criteria to delineate viability of the western pearlshell mussel populations (Nature Serve 2009a, RanksA-F: A- excellent viability, B-good viability, C-fair population, not viable, D-not viable, E-verified extant, F-absent, failed to find evidence of a population, H-Historical Verified Site, population now absent) .

A viability: Densities $>1$ per meter of stream, mussel beds containing $>50$ individuals, full range of size-classes, mussels $<30 \mathrm{~mm}$ (juveniles present) B viability: Densities $>0.5$ per meter of stream, mussel beds containing $>25$ individuals, wide range of size-classes, mussels $<30 \mathrm{~mm}$ (juveniles present) C viability: Low Densities > 0.1 per meter, mussel beds <25ind., limited size-classes, no juveniles present. May persist for 25 years from present.

D viability: Very Low Densities, single live individuals. Large size-class, old specimens Will not persist 25 years from present.

E verified extant: Recent shell records, but no live mussels found. 
Viability of eastern Montana's warmwater mussel species was judged qualitatively by best professional judgement, because we rarely observed traditional mussel beds, rather we usually documented randomized clumps of individuals never exceeding 50 individuals per survey reach. The number of live and recent shells in the survey and size distribution of the individuals was main statistics used to judge viability of the population (Strayer \& Smith 2003).

\section{Habitat Sampling}

The quality, distribution, and continuity of habitat at multiple spatial scales (river sections, entire rivers, and entire watersheds) can provide an important context when assessing the health of mussel populations. This information is particularly valuable when gathered in the same location over a long time period (i.e., long-term monitoring), or used to compare populations in different portions of rivers, across rivers, or entire watersheds. In this study we described in-stream substrate (i.e., fines, sand, gravel, cobble-boulder, and bedrock), channel depths, bank type (steep mud banks, limestone outcrops, vegetated versus non-vegetated) and riparian habitats as they relate to mussel populations within the historic and current watershed distribution of target mussel species. We evaluated stream reach habitat following methods outlined for the EPA by Barbour et al. (1999) with modifications by the National Aquatic Assessment of the Bureau of Land Management (BLM) Buglab (scores 0-24) (http://www1.usu.edu/buglab/forms/Bug\%20Protocol\%20form.pdf).

\section{Data Management}

Prior to this study, information regarding the distribution of Montana's freshwater mussels (e.g., collections and databases maintained by state universities, and individuals) was minimal and not readily accessible to any one individual or agency. We constructed a comprehensive database for mussel reporting that links to a jointly managed database shared by Montana FWP and NHP. This database includes locality information, habitat, mussel survey data, as well as status information for presence data (i.e., number of live specimens, recently dead valves, relic valves and viability ranks) of all mussel species occurring in the state. The database interfaces with MTFWP MFISH info systems and to a GIS mapping application that can be viewed online with the Tracker application, http://mtnhp.org/Tracker/NHTMap.aspx . This allows data access to individuals and agencies involved in the conservation and management of aquatic ecosystems and freshwater mussels. 


\section{RESULTS \& DISCUSSION Overview}

We conducted 1150 standardized mussel surveys across the state and into Idaho from 20072009, and compiled previous surveys and information into a database of 1330 mussel sites from 94 of the $1004^{\text {th }}$-code watersheds (Map2, Appendix B). These surveys extrapolate to about 508 km or 316 miles of stream habitat searched for mussels. Data was compiled for all six mussel species reported to occur in MT: 202 site occurrence records for the western pearlshell, 146 fatmucket records, 92 giant floater sites, 41 sites for the black sandshell, six mapleleaf sites and five creek heelsplitter records. Of the 975 negative mussel searches (no live individuals) recorded during this time period, 120 sites had dead shells, so 855 sites reported no evidence of mussels (Figure 3). The highest percentage of negative mussel

Map 2. Distribution of mussels in Montana based on surveyed sites and literature records. Yellow highlighted regions are $5^{\text {th }}$ code HUC watersheds depicted as positive for mussel presence.

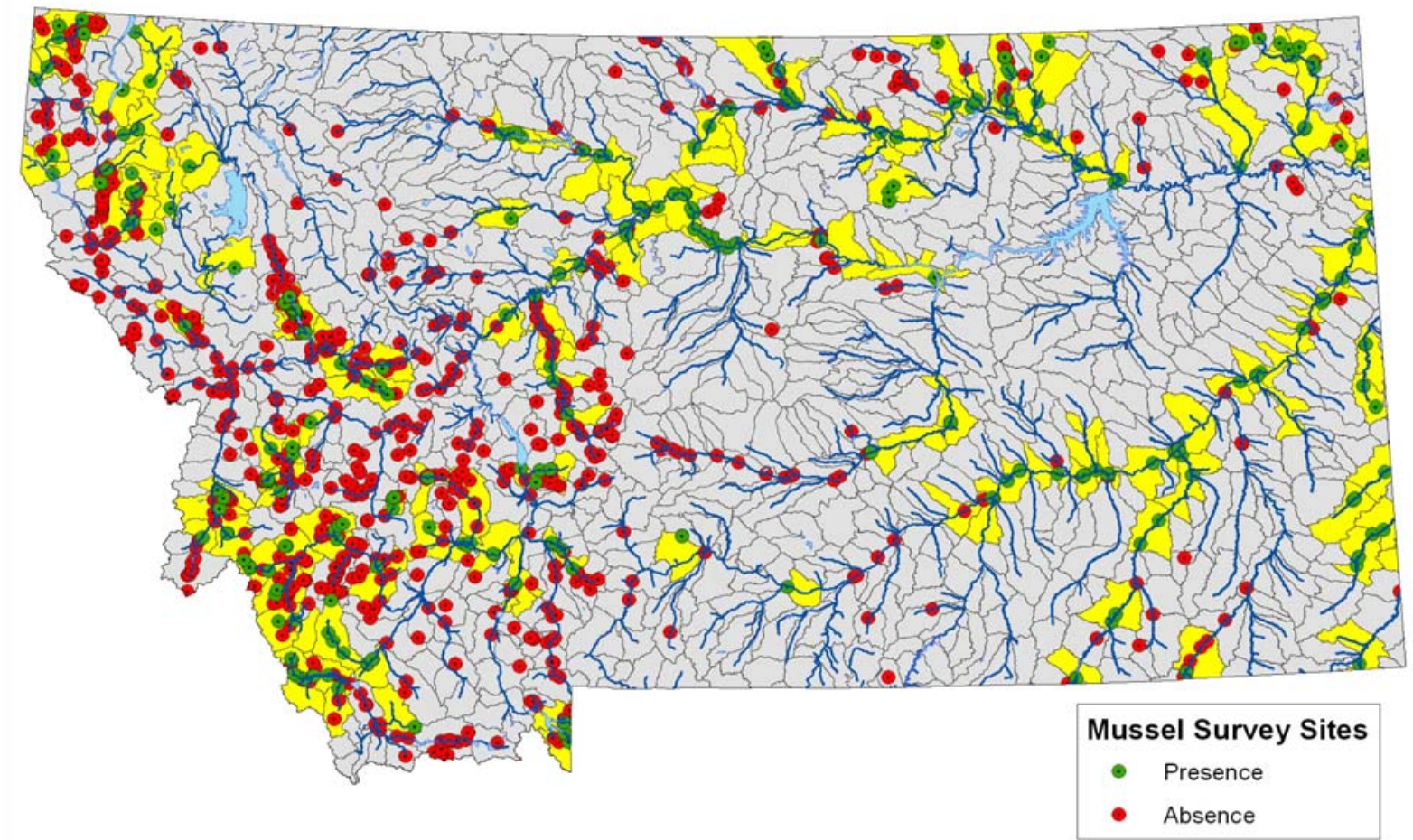

searches occurred for the western pearlshell at $81.2 \%$ or about $18.8 \%$ detection probability. Eastern Montana’s warmwater mussels were encountered with a much higher probability ( 33\%); approximately one in every three river segments that we sampled contained evidence of mussels. This could be due to a sampling emphasis on the Mainstem Rivers and larger 
prairie streams that are documented to contain water year round and not recording the number of dry streams that were not sampled. Despite large sampling gaps on Indian Reservations and in eastern Montana, patterns of mussel distribution at the watershed level begin to appear. Connectivity of riverine systems correlates to more $5^{\text {th }}$ code watersheds within a given basin containing mussel populations. This is most evident in the Yellowstone River and the Middle Missouri River, but surprisingly also exists in the Milk River Basin which contains numerous diversion dams (Map 3). Western river systems showing mussel population connectivity include the Yaak, Thompson, upper Fisher and Big Hole Rivers, and portions of the upper Beaverhead (Map 3).

Map 3. Watershed distribution of mussels in Montana based on positive survey points within the $5^{\text {th }}$ code HUCs. One positive mussel occurrence is the threshold for presence in the watershed.

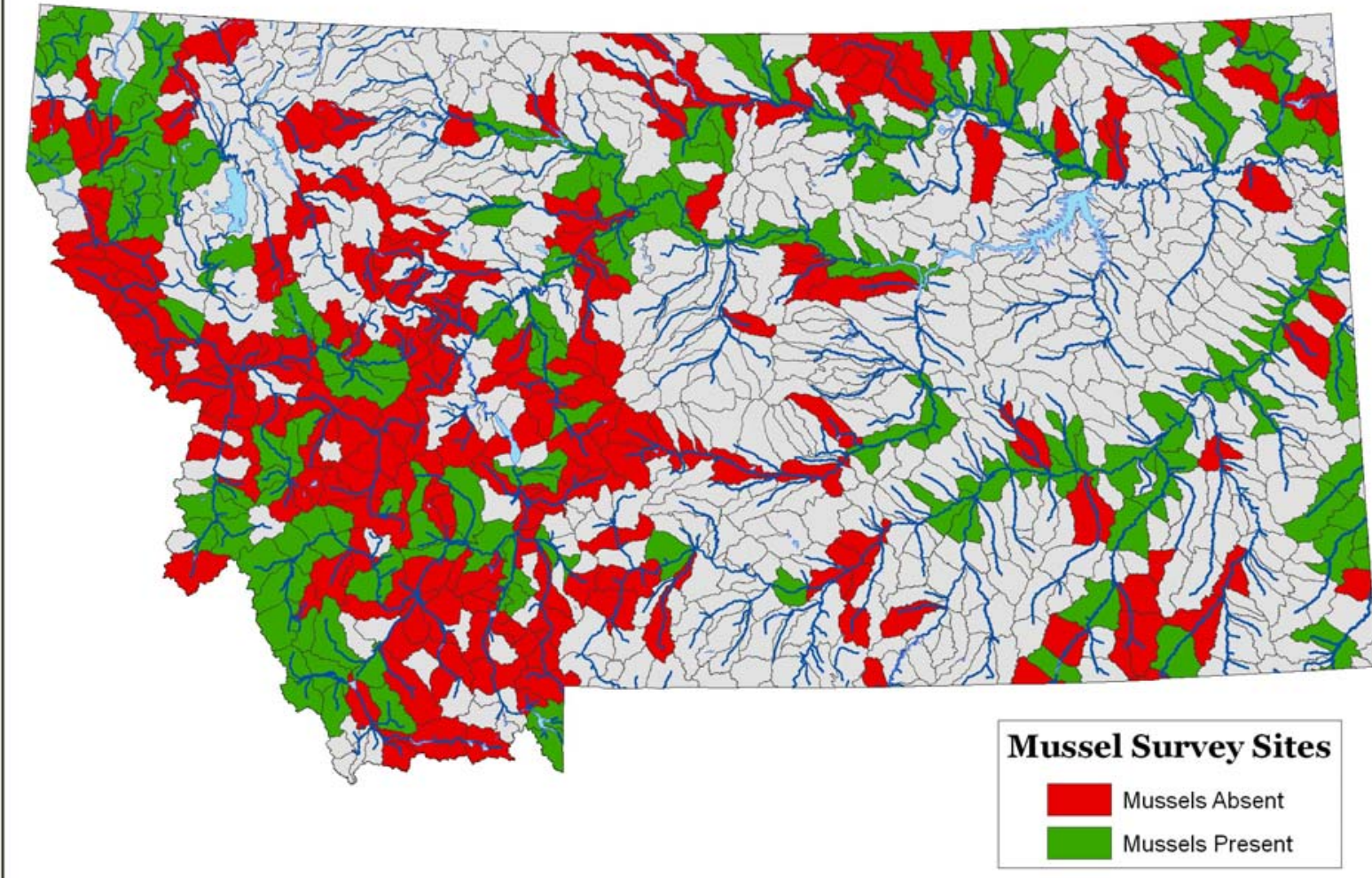

Most mussel populations in Montana are not abundant, 92\% of surveys in the database reported between 0-5 individual mussels; $64 \%$ of the sites with live mussels had only 1-5 individuals (Figure 5). The number of live individuals per survey reach in MT varied from zero to 480 (Figure 5). The Clearwater River reach with 480 Margaritifera falcata per hr extrapolated to 
3,000 mussels per kilometer of river. While in Idaho, during some $M$. falcata surveys we collected as many as 876 mussels per reach ( 7,000 per km) (Figure 5).

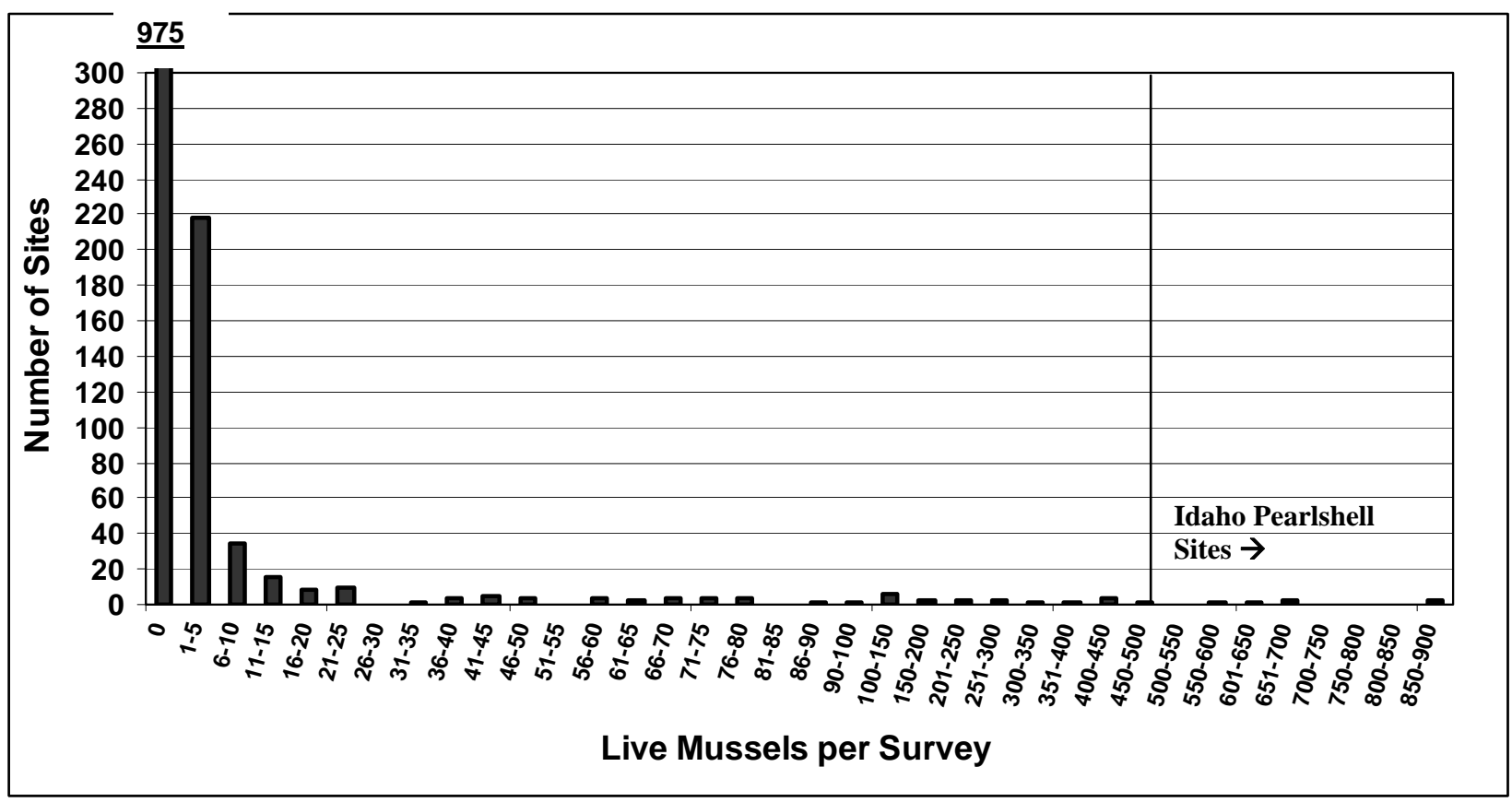

Figure 5. Number of live mussel individuals per survey site in Montana and Idaho.

The number of mussel species per site varied from zero to four (Appendix 2) with one species being the median at sites with at least one species present. In the Columbia River drainages of the west only one species, $M$. falcata is expected; fatmuckets only overlap with the western pearlshell in the Three Forks-Jefferson River area where western pearlshells are virtually gone (shells, but no live found) and fatmuckets have fair populations. Evidence of this co-existence dates back >2,000 years at an pre-historic chert mine site, where unearthed western pearlshells outnumbered fatmucket shells 4:1 (Lippencot and Davis 2000). While not scientific, this discovery indicates that western pearlshells were certainly more abundant in the river, more easily collected or preferred by Native Americans. Four of the five potential eastern mussel species were collected in the Milk River near Bjornberg Bridge sp Catch-per unit-effort (CPUE) for Montana varied from 0 to 480 individuals per hour (Appendix 1), while Idaho western pearlshell sites reported up to 880 mussels per hour of search.

The introduced creek heelsplitter have increased their upstream distribution in the Milk River system, but not to the extent that the black sandshell have expanded their range.

The introduced mussels in Montana do not seem to be negatively affecting the native species, coexistence and non-exclusion is evident in stream reaches documented to have both present. 
But rather, they seem to be an augmentation to the mussel fauna of the state and in the case of the black sandshell seems to be more viable in the upper Missouri River than in its native sections of the Missouri River downstream where it is state listed as imperiled (S1) in South Dakota and Iowa (Nature Serve 2009).

Concurrently with the field surveys, we conducted six mussel identification and survey techniques workshops to $\sim 70$ fisheries biologists and hydrologists across Montana and into Idaho. Attendees of these workshops reported back data for an additional 100 survey reaches, including the identification of two new viable western pearlshell sites in 2009. Throughout the course of these surveys, we found no evidence of the western-ridged mussel, Gonidea angulata in our searches of the Columbia River basin tributaries and have listed this species as SH-SX, presumed to be extinct or extirpated from Montana; historical records only (NatureServe 2009). 


\section{Western pearlshell Margaritifera falcata (Gould)}

\section{Global Status: G4G5 State Status: S2}

Abundance: Regionally uncommon, can be locally common, but in serious decline and at risk statewide, especially the upper Missouri River populations. Species of Concern in Montana, Wyoming and Idaho; potentially extirpated in Utah.

Description: Elongate shell is normally 2.5-4 inches $(50-80 \mathrm{~mm})$ in length with a concave ventral edge. Interior shell (nacre) has a purple to pink hue. Outside of shell can be dark brown to black with a whitish tan area where the umbo (dorsal hinge) has been worn down.

Host Fish: Native species: Westslope Cutthroat Trout, Steelhead and Chinook Salmon (Idaho). Introduced Species: Rainbow and Brook Trout.

Habitat: The species is found in cool-coldwater, stable running streams and rivers that are generally low to moderate gradient (1-2\%) and wider than $2 \mathrm{~m}$ (average wetted stream width of viable populations $=5.2 \mathrm{~m} \pm 1$ ); preferable benthic substrate is stable gravel and pebble $(\%$ dominant substrate size $=32 \mathrm{~mm})$. Generally, this stream type is equivalent to a Rosgen Class C4. The riparian zone is usually dominated by willows or alders. This species can occur in sand or gravel among cobble and boulders in moderate to higher gradient larger rivers. In large Idaho river systems (Salmon and Clearwater River Canyons), $M$. falcata, attains maximum density and age in river reaches where large boulders structurally stabilize cobbles and interstitial gravels (Vannote et. al 1982).

Margaritifera falcata may be one of the longest living freshwater invertebrates and animals overall. The oldest known specimens have been aged at greater than 90 years (Toy 1998), 100 years (Vannote and Minshall 1982) and $>100$ years old (Stock 1996).

Boulders tend to prevent significant bed scour during major floods, and these boulder-sheltered mussel beds may be critical for population recruitment elsewhere within the river, especially after periodic flood scour of less protected mussel habitat. Stream velocities affect intra-stream habitat selection of this mussel (Oswald 2008) with stream gradients of $1.4 \%$ containing 
mussels and those averaging 2.4\% absent of mussels. Mussels will not occur in streams where the substrate is substantially disturbed by torrents (Toy 1998). M. falcata is found in hard as well as soft water, unlike M. margaritifera (Clarke 1981). Glochidia of $M$. falcata are highly host specific (Bauer 1987) and are generally restricted to the salmonid family.

Distribution: Prior to this study, there were only 40 occurrence records in the database, now we have 202 records (Map 4). While researching for the Comprehensive Fish \& Wildlife Conservation Strategy (CFWCS 2005), limited distribution or population viability data on Margaritifera falcata existed for Montana, and this species was listed as "stable” by Gangloff and Gustafson (2000), but as a Potential Species of Concern for MT (S2S4, MNHP and MFWP 2004). At that time, surrounding states had it listed as state-threatened (S3 in Washington) or unranked, but declining in neighboring states Wyoming, Idaho (G. Stephens, pers. Comm.) and Oregon (NatureServe 2005). In the course of preparing the CFWCS, M. falcata was

\section{Map 4. Distribution of the Western Pearlshell in Montana based on positive survey points. Recent shells collected in the survey also constitute "positive" records.}

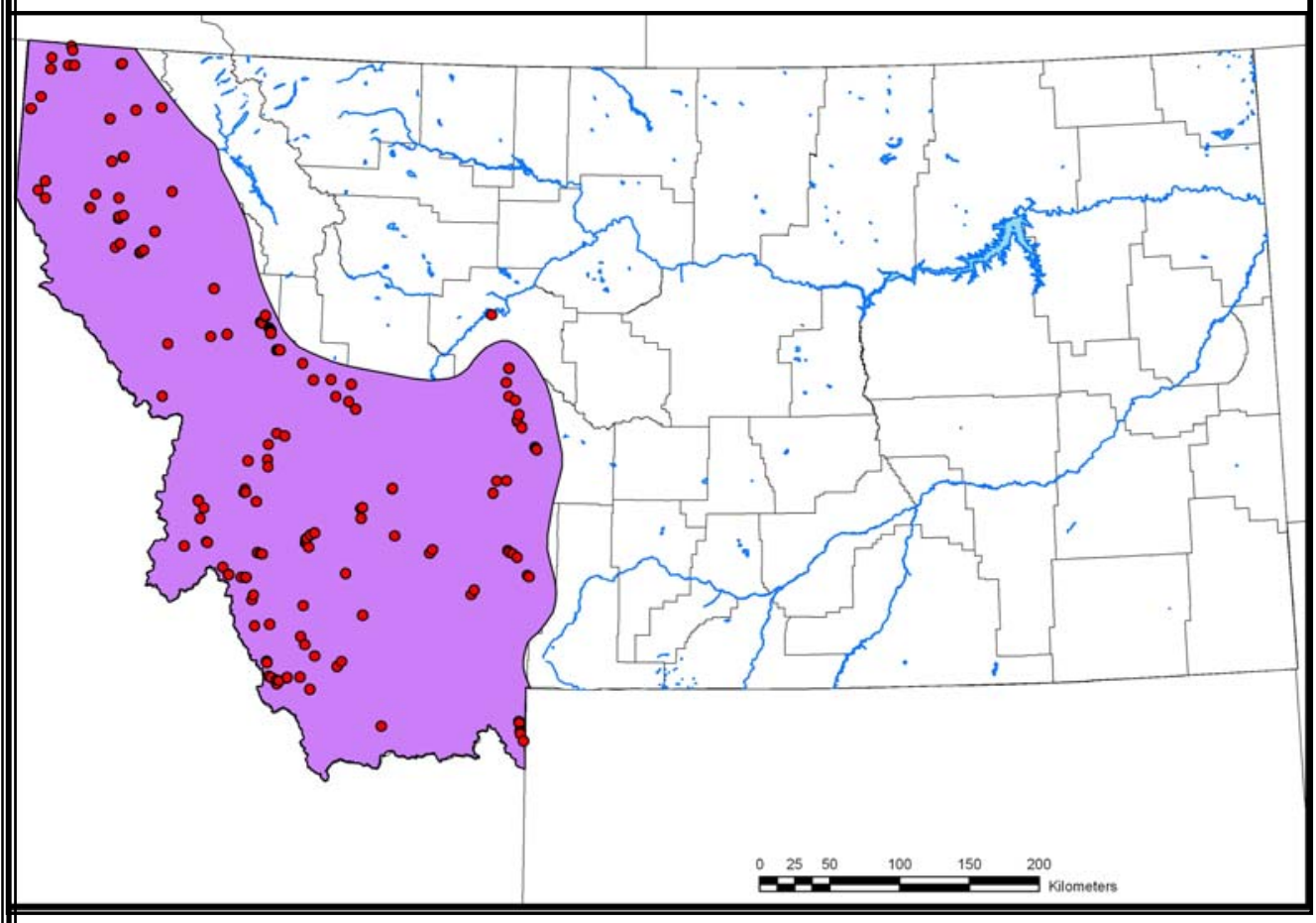

determined to be an invertebrate species of greatest conservation need (Tier I). In 2005, I reported the western pearlshell from two sites on the Smith River in Meagher County; the furthest eastern population of $M$.

falcata reported for the state, and a new viable population in the Clearwater River (Stagliano, unpublished). In 2007, the first year of this project, we focused on systematic surveys of the watersheds containing previously documented or historical records (many were incidental shell or relic records) of M. falcata, including site revisits for Gangloff and Gustafson (2000) collections. Results from this year were discouraging, 25 of the $\sim 40$ originally reported sites 
were extirpated or not viable (D, E ranks) and only 5 new viable populations (A, B ranks) were documented. So, while the updated distribution map shows that the western pearlshell are widespread in western Montana, the viability of these populations is a different story (Map 5). At present, we documented only 14 western pearlshell populations from 8 streams statewide that are ranked A-viability using Nature Serve criteria (Map 5). In a viability analysis, 32 living populations of $M$. falcata were evaluated with quadrat sampling and it was found that only 15 sites had young mussels present An upcoming project addressing western pearlshell reintroductions into restored stream reaches should provide guidance for the potential of returning this species to previously occupied watersheds.

Map 5. Viability of Western Pearlshell populations in Montana and Idaho based on positive survey points. Recent shells collected in the survey with no live mussels are included as poor records.

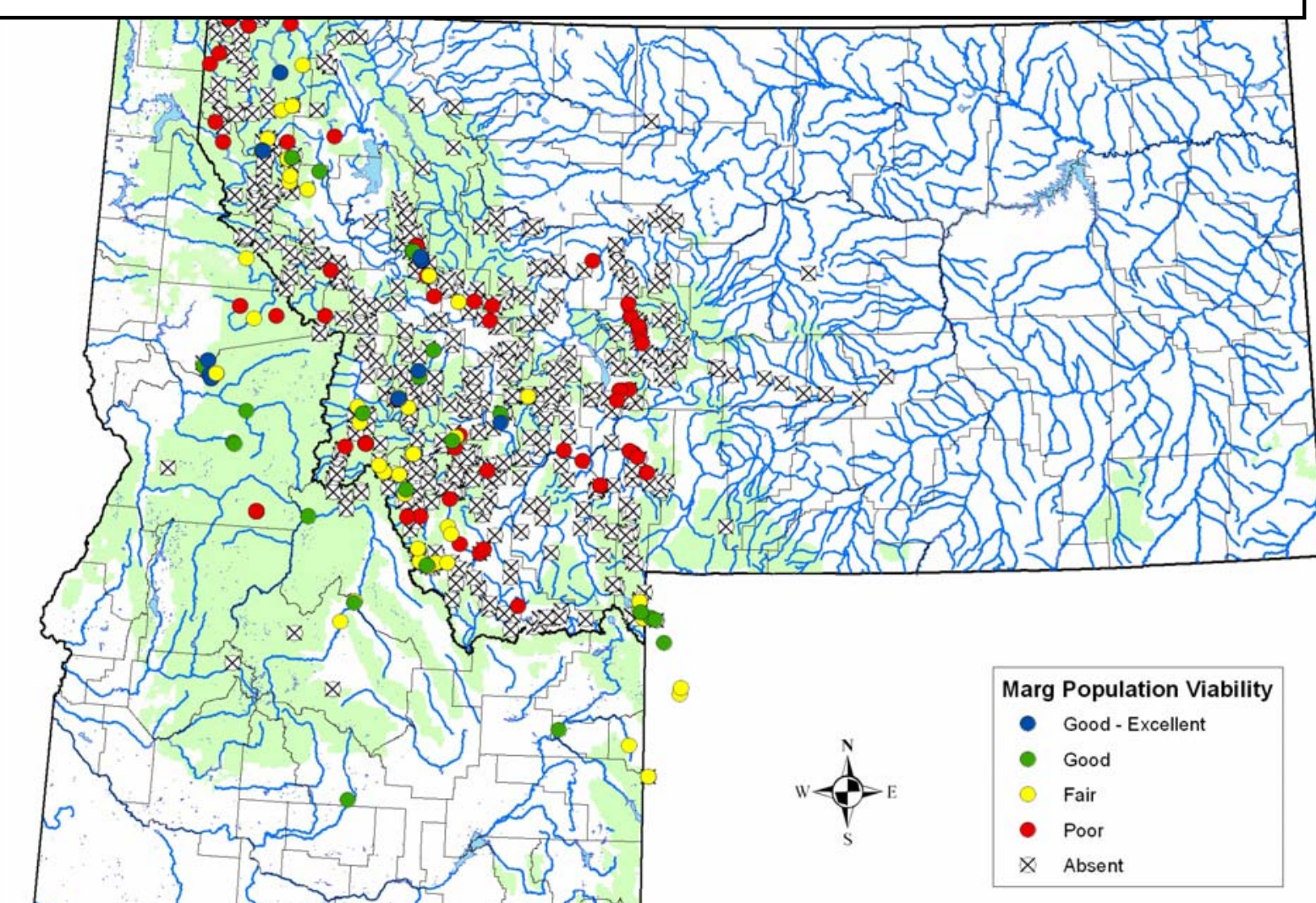

Key Watersheds: Within the Upper Missouri River Basin: tributaries to the Beaverhead and Big Hole (Bloody Dick, Deep, and Clam Creeks) and upper Madison River hold viable populations. In the Upper Clark Fork Drainage, Upper Rock Creek Basin in particular Upper Willow, Browns Gulch and Sand Basin Creeks are viable. Viable populations also occur in the Blackfoot-Clearwater Basin (Marshall Creek and Clearwater River) and the Thompson River, Kootenai-Yaak River (East Fisher, Little Wolf, and 5-mile Creek)( see Appendix C). 


\section{Western-ridged Mussel Gonidea angulata}

\section{Global Status: G3 State Status: SH-EX}

\section{Abundance: Potentially At Risk Globally, Regionally rare, Locally extirpated, and in decline in adjacent states.}

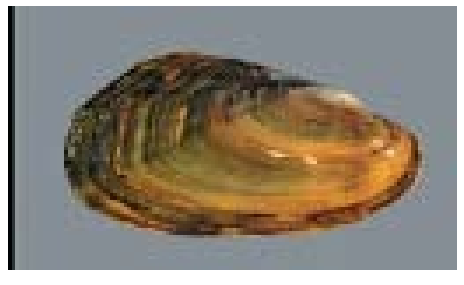

Throughout the course of this study, we found no evidence of the western-ridged mussel, Gonidea angulata, in our searches of the Columbia River basin tributaries or other data searches and have listed this species as SH-EX, presumed to be extinct or extirpated from Montana; historical records only (NatureServe 2009). There exist no museum specimens or mention of this species by Elrod (1901), only anecdotal records. Henderson (1924) reported the species locality as the Columbia River, Montana; which as Gangloff and Gustafson (2000) postulated could have been the Clark Fork River or the Kootenai Rivers in the Columbia River basin. The potential for occurrence of the western ridge mussel (Gonidea angulata), may have existed in Montana in the lower Clark Fork River before Cabinet Gorge dam formed Noxon Reservior adversely affecting lotic habitat and fish passage (Frest and Johannes 1995). Since Elrod (1901) reported extensively on mollusks in western Montana, we can only assume he would have mentioned this species had he encountered it during his surveys. Across the border in Idaho, populations were known to occur in much of the Snake River, Clearwater River, Salmon River, and the Little Salmon River (Frest and Johannes 2000). These documented Idaho sites are very distant from where the Clark Fork River enters the state from Montana causing further doubt as to whether this species ever existed in Montana. 


\section{Fatmucket Lampsilis siliquoidea (Barnes) \\ Global Status: G5 \\ State Status: 55}

Abundance: Globally and Regionally Common. Locally common, but never very abundant, secure populations, our most widely distributed species.

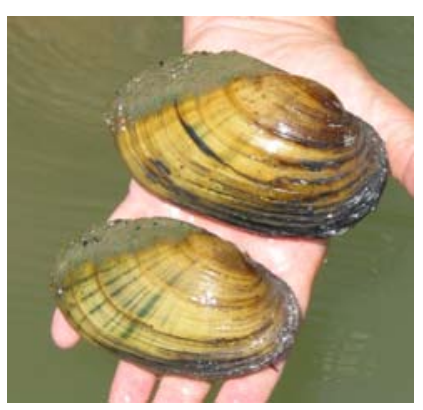

Description: Shell is 4 to 6 inches across. Generally heavy shell with large hinge teeth. Males tend to be thinner; females can be highly inflated laterally. Outside of shell can be light brown, yellowish to tan, often w /greenish rays; inside is white.

Host Fish: Native species: Freshwater Drum, Catfish, Stonecat, Sturgeons \& White Sucker. Introduced Species: Common Carp, Black Bullheads, Centrarchids and Yellow Perch.

Primary Habitat: Prefer side-current areas, runs and pools of medium to large warm prairie rivers with pebble, gravel, sand or silt substrates. In Montana, they can be found as far upstream as the Three Forks of the Missouri River and into the Jefferson River. This mussel is fairly tolerant of silt, cool and warm water temperatures.

Distribution: Prior to this study, there were only 12 fatmucket records in the database, now we have 146 occurrence records (Map 3). We report that the highest population density of the fatmucket is found within the Wild \& Scenic Section of the Missouri River between Fort Benton and Judith River landing (avg. 8.2 fatmuckets per hour, $n=12$ survey reaches,

Map 6. Distribution of the Fatmucket in Montana based on positive survey points.

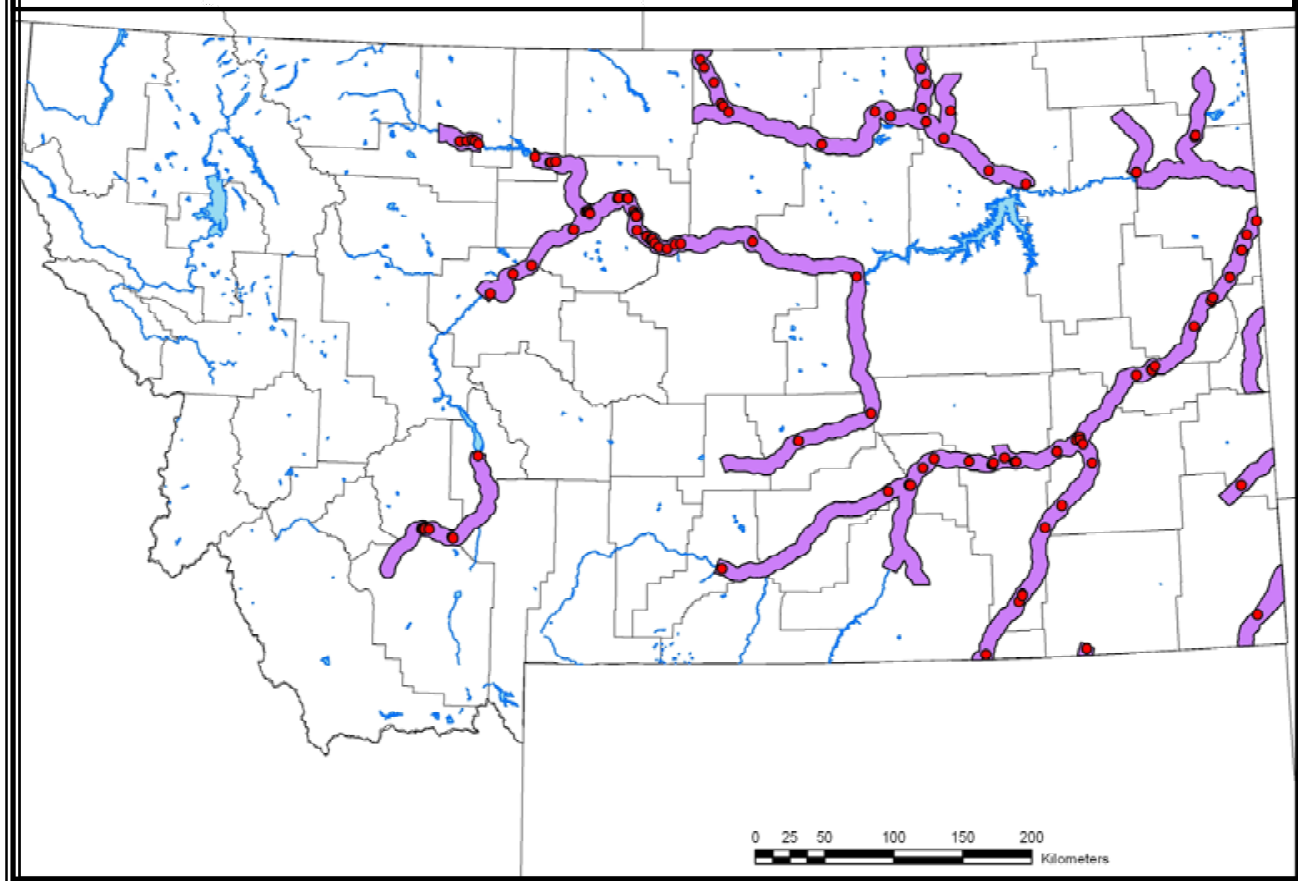

maximum 38 per hour) with Marias River populations approaching those densities (7 per hour). Our surveys in the Yellowstone River mainstem indicate that this river has much lower mussel densities overall, with 
fatmucket catch rates averaging $\sim 1$ per hour. While large prairie tributary rivers entering the Yellowstone have higher densities; two sites on the Bighorn River had fatmuckets avg. 6 per man-hour or about 3 mussels per 50m transect and the Tongue River averaged. 6 per manhour.

Key Watersheds: Within the Missouri, Marias, Milk, Yellowstone and Little Missouri River drainages. Highest densities are found in the Missouri River Wild and Scenic reach from Fort Benton to Judith Landing and in the Marias River above Lake Elwell and near the confluence with the Missouri. They are also present in moderate numbers in the Tongue and Bighorn Rivers in the Yellowstone Basin and Battle and Beaver Creeks in the Milk River Basin.

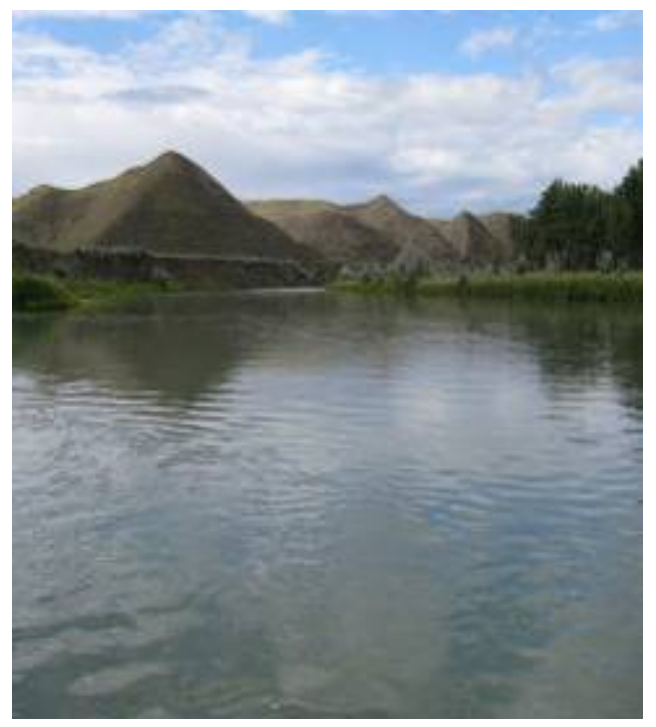




\section{Giant Floater Pyganodon grandis (Say)}

\section{Global Status: G5}

State Status: $\mathbf{S 4}$

Abundance: Globally Common, Regionally and Locally common, more secure populations are located in northeastern MT.

Description: Shell is up to 6 inches across. Generally thin, elliptical

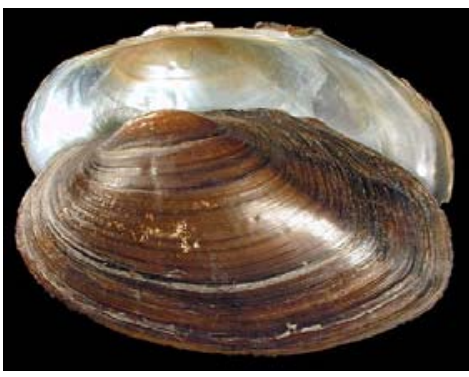
and light weight. Hinge ligament has no teeth - hence the previous genus name of "Anodonta". Shell color is brownish to tan-yellow-green; inside is pearly-blue sheen.

Host Fish: Native species: Iowa Darter, Brook Stickleback, Pearl Dace and Channel Catfish. Introduced Species: Common Carp, Yellow/Black Bullhead, Centrarchids and Yellow Perch.

Primary Habitat: Prefer pool and side channel areas of small to large warm prairie rivers with a mud, sand or gravel substrate. This mussel is tolerant of silt and warm water temperatures. The ability of this species to survive in lentic situations is evident by large mussel beds reported in Lake Elmo outside of Billings (Ken Frazier, pers. comm.) and in Whitetail Reservoir near Scoby (Gangloff and Gustafson 2000).

Distribution: Prior to this study, there were only 16 giant floater records in the database, now we have 92 occurrence records (Map 4). A giant floater shell was found in the Tongue River upstream of the Reservoir in 2004 and a single shell in the Little Powder River in 2007, but live

Map 7. Distribution of the Giant Floater in Montana based on positive survey points.

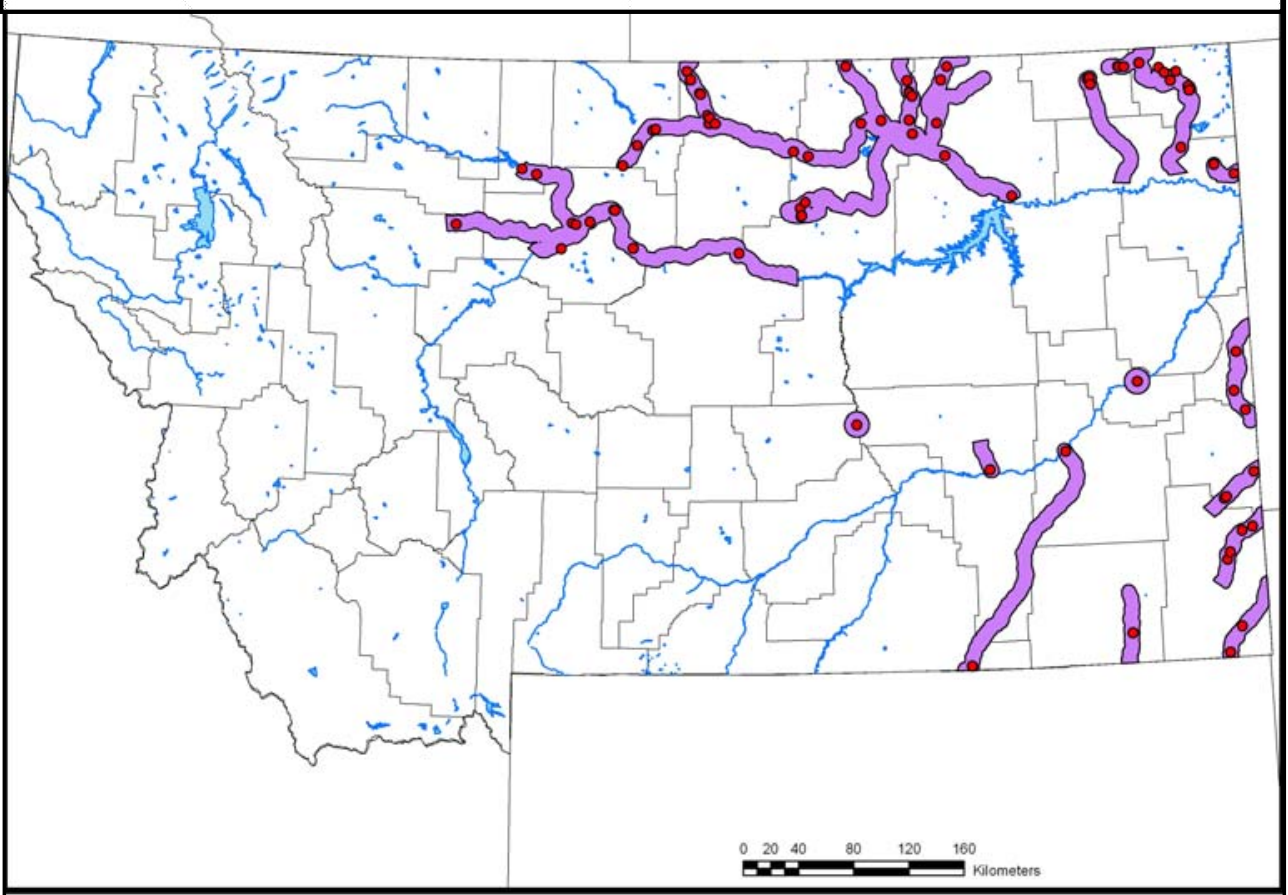

individuals were not reported (origin of shell potentially dubious). In 2009, we documented the first live records of the giant floater in the Yellowstone Basin at 3 tributary sites (O’Fallon, Little Porcupine, Tongue River), but no evidence has been found of live specimens of this species in the Yellowstone River mainstem. 
Key Watersheds: Within the Missouri, Milk and Little Missouri River drainages, more evenly distributed and abundant in the Northern Glaciated Prairie River Basins (Battle, Big Muddy, Frenchman, Poplar River and Rock Creek). Moderate populations in the Little Porcupine and lower Tongue River in the Yellowstone Basin. 


\section{INTRODUCED SPECIES ACCOUNTS}

\section{Black Sandshell Ligumia recta (Lamarck) \\ Global Status: G5 \\ State Status: SNA}

Abundance: Globally Common, Regionally rare (species of concern S2 \& S3 in many Midwestern states), locally abundant in MT. Increasing distribution and populations in the Missouri River basin.

General Description: Elongate, pointed shell normally 4-6 inches long with a convex ventral edge. A large, older specimen may be 7-9 inches $(>16 \mathrm{~cm})$ making it the largest mussel in MT. Shell interior (nacre) has a purple to pink hue, especially in fresh specimens. Outside of shell can be dark brown to black with a whitish tan area where the umbo (dorsal hinge) has eroded.

Host Fish: Native Species: Sauger. Introduced Species: Walleye, Yellow Perch \& Centrarchids.

Primary Habitat: Medium to large cool-warm prairie rivers in riffles or runs with pebble, gravel or firm sand substrates. In the Wild and Scenic Section of the Missouri River, the black sandshell has been observed in higher velocity, cobble substrate areas than any of the other species. This mussel is fairly intolerant of silt and warm water temps.

Distribution: Prior to this study, there were only 9 Black Sandshell records in the database, now we have 41 occurrence records (Map 5). Highest catch rates (4 per man-hour) were reported in the Missouri River Wild and Scenic reach between Coal Banks and Judith Landing.

Map 8. Distribution of the Black Sandshell in Montana based on positive survey points.

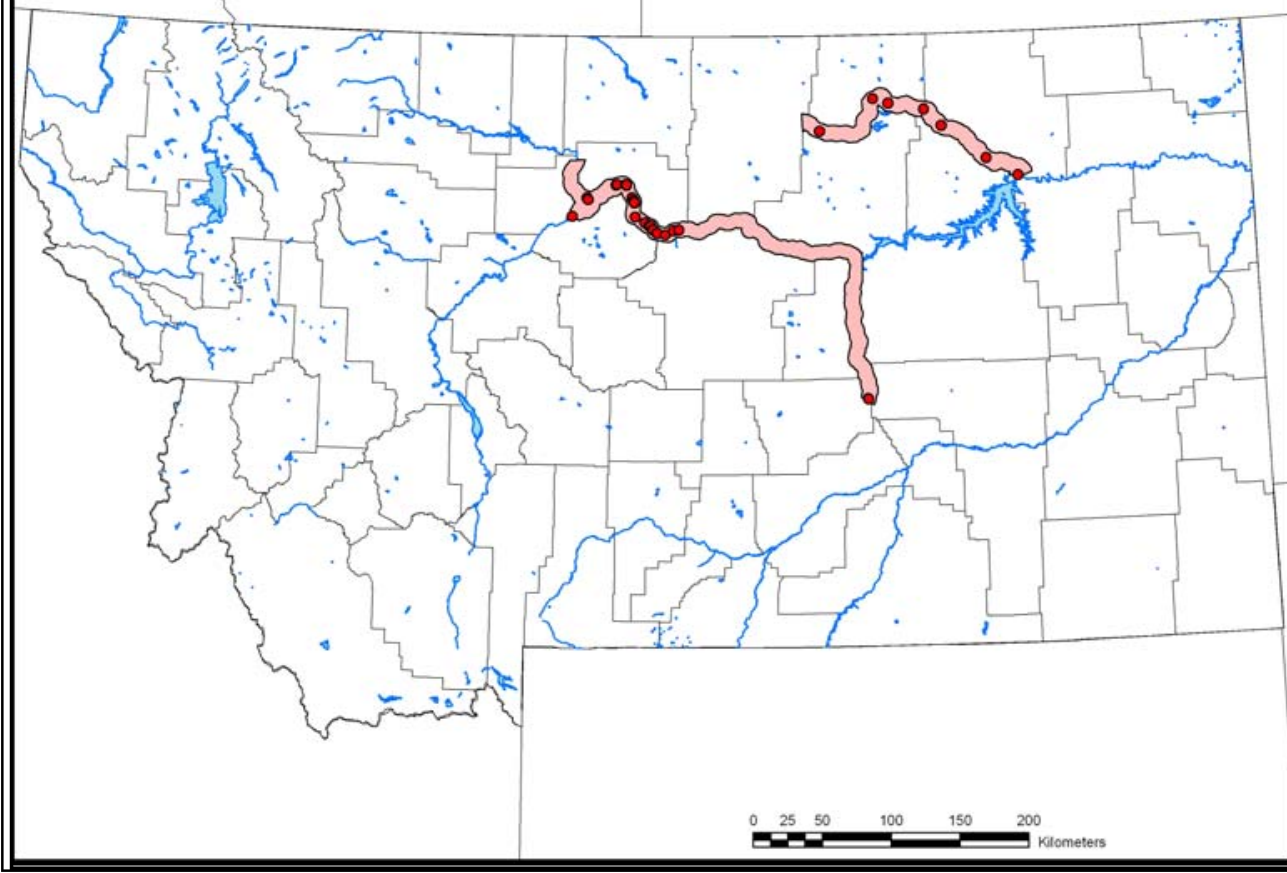

A 2009 survey in the Marias River has extended their distribution 8 miles further upstream in that river than previously known from 2008.

Key Watersheds:

In the Missouri,

Musselshell and

Milk Rivers, spreading upstream from a 
Fort Peck Reservoir introduction. Highest densities have been reported in the Missouri River

Wild and Scenic reach upstream from Fort Benton to Judith Landing and the Milk River near Dodson downstream to Malta.

Who says mussels can't move?

The Introduced Black Sandshell \& Creek Heelsplitter Mussels are linked to fish stocking events in Fort Peck Reservoir when the Missouri River was dammed in 1940. Now the Black Sandshell is abundant 120 miles upstream @ Fort Benton, MT. 


\section{White (Creek) Heelsplitter Lasmigona complanata (Barnes)}

\section{Global Status: G5 \\ State Status: SNA}

Abundance: Regionally common and locally abundant, increasing distribution in the Milk River basin.

Description: Ovate shell rounded and laterally compressed,

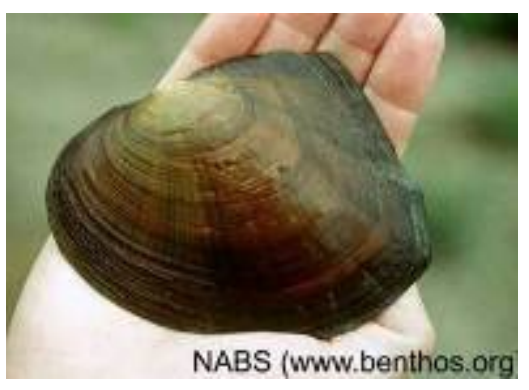
normally 4-6 inches long and about as high as long. Dorsal margin straight with a large wing (hence "Heel-splitter"). Outside of shell dark brown to black. Young individuals can have green rays (bottom photo). Shell interior (nacre) with a bluish-pearl to white hue.

Host Fish: Native species: Sauger. Introduced Species: Common Carp, Green Sunfish, White Crappie, Largemouth Bass

Primary Habitat: Pools in medium to large sluggish prairie rivers with a mud, sand, or fine gravel bottom. They are not found in stream reaches with fast current. This species is tolerant of silt and warm temperaures.

Distribution: Prior to this study, there were only 5 Creek Heelsplitter records in the database, now we have 6 occurrence records (Map 5).

Map 9. Distribution of the White Heelsplitter in Montana based on positive survey points.

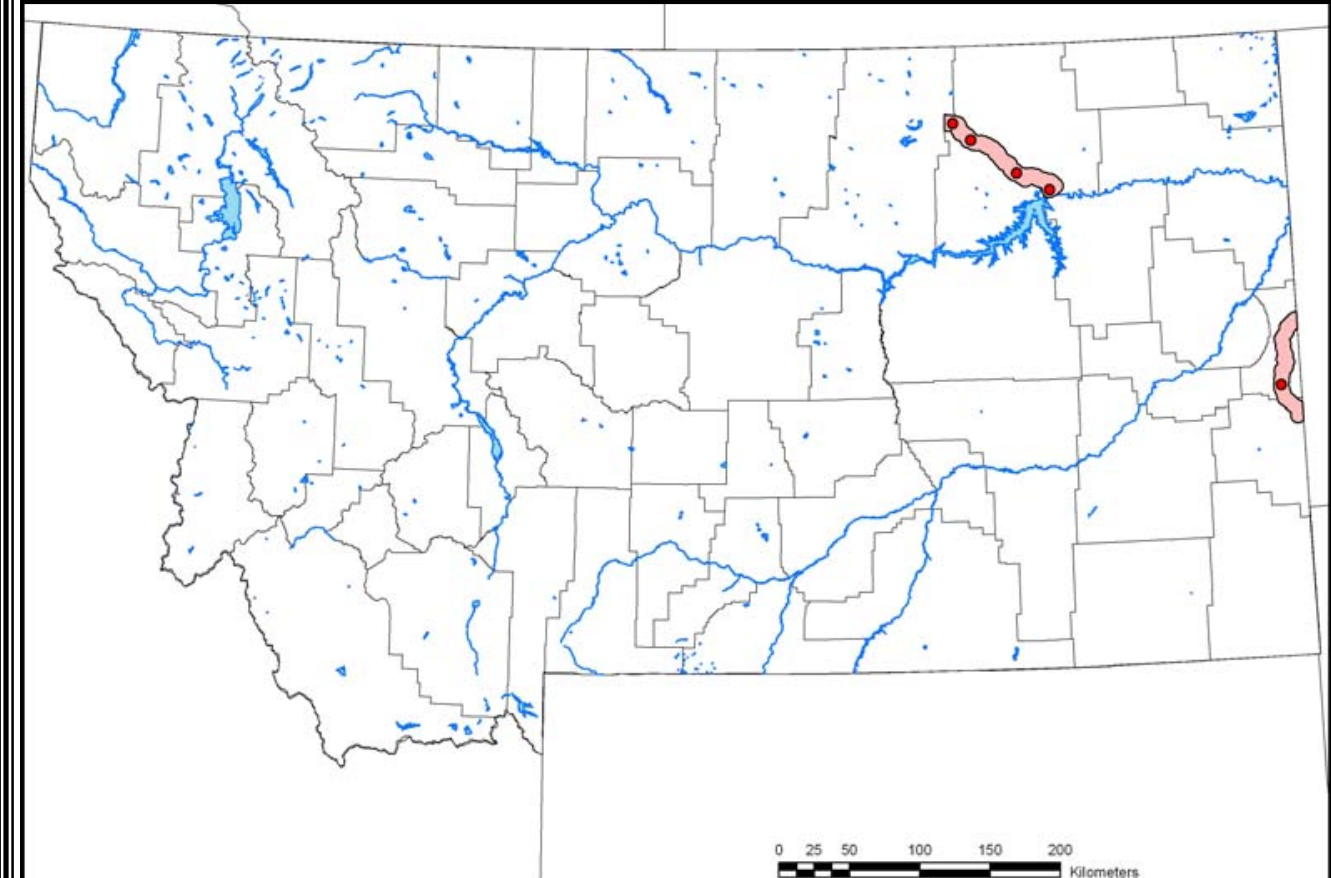

Key Watersheds: In the Missouri Basin, known only from the Lower Milk River near the confluence upstream to Bjornberg Bridge, and in Beaver Creek, a tributary of the Little Missouri River. May be native in the Little Missouri River basin, since they are native in North Dakota. 


\section{Mapleleaf Quadrula quadrula (Rafinesque)}

\section{Global Status: G5 \\ State Status: SNA}

\section{Abundance: Globally common. Regionally common where native, and locally abundant in the Tongue River.}

Description: Ovate shell thick and heavy, normally 3-5 inches long and about as wide as long. Outside of shell

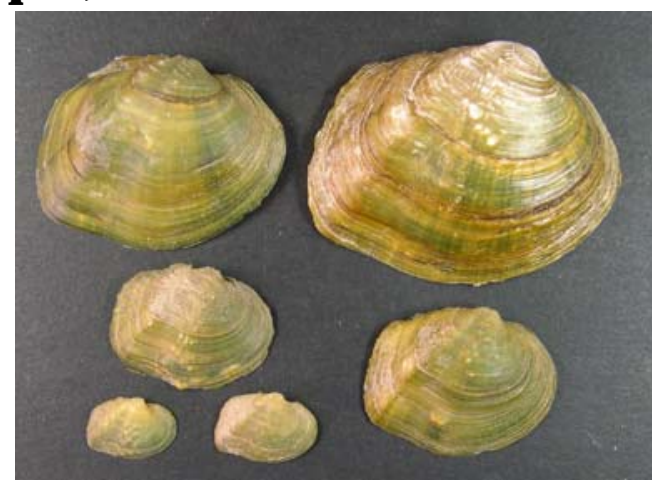
tan, “maple-syrup,” (especially in younger individuals) to dark brown. Generally 2 rows of "bumps" pustules on raised ridges. Shell interior with thick teeth and a white hue (nacre).

Host Fish: Native species: Channel Catfish. Introduced Species: Yellow and Black Bullhead

Primary Habitat: Low elevation warmwater, slow-moderate flowing rivers, tolerant of silt and warm water temperatures.

Distribution: The mapleleaf was not included in Montana's mussel species documented by Gangloff and Gustafson (2000), but was reported a year after the publication in the Tongue River at the 12 Mile Dam location (D. Gustafson, unpuplished data). In 2009, our surveys indicated the mapleleaf had good numbers in the Tongue River near the confluence ( 10 ind.

Map 10. Distribution of the Mapleleaf in Montana based on positive survey points.

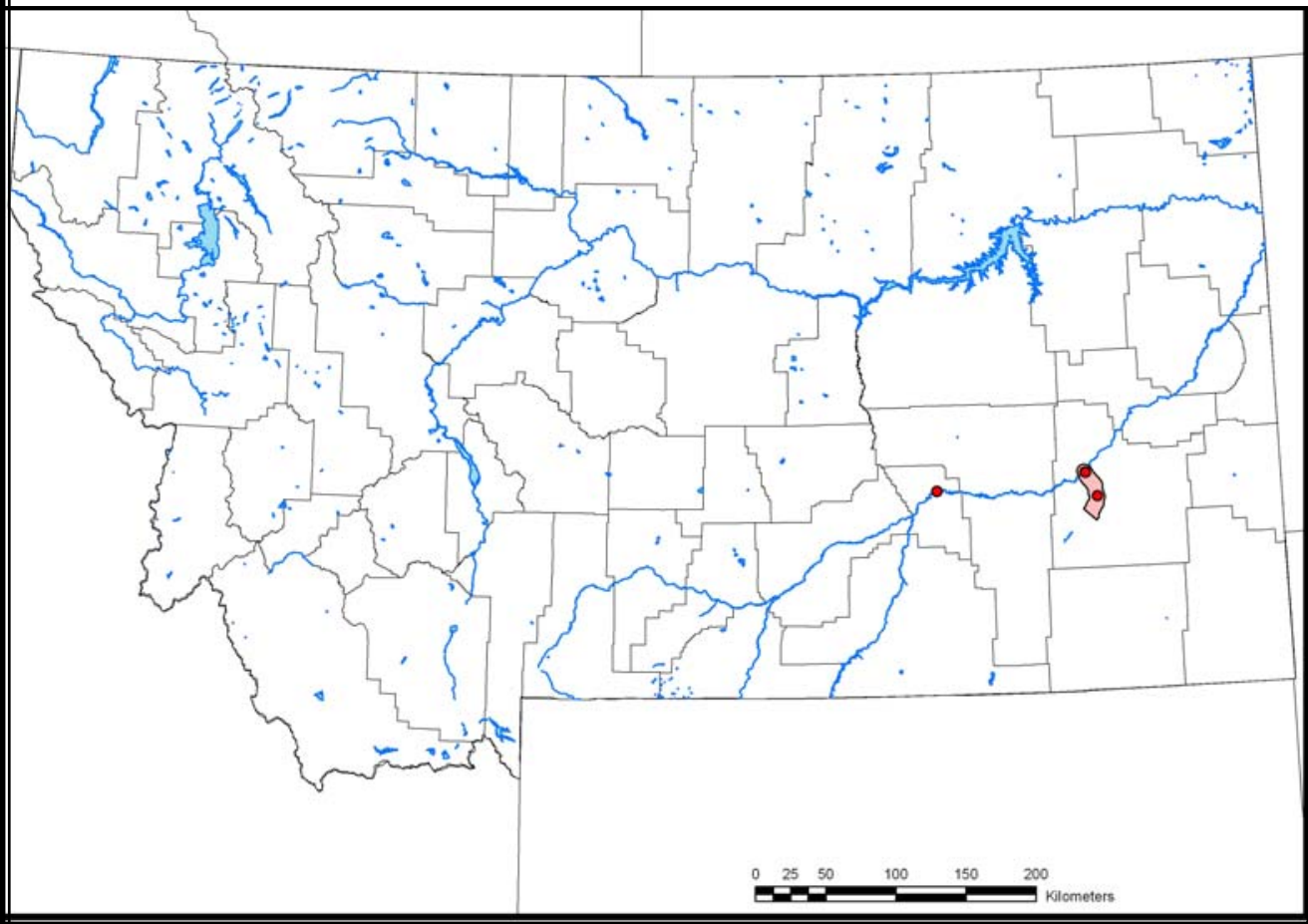

per hr) and below the 12 mile dam location $(\sim 8$ per hr), but was not found upstream in the Tongue River or live in the Yellowstone mainstem. There was a report of mapleleaf shells near Hysham much further upstream on the Yellowstone 
River from the Tongue River (valid identification of the shells, but of questionable origin). It is surprising that this species was not found during our other surveys upstream on the Tongue River, since we believe the point of introduction to the state was Tongue River Reservoir. Outside of Montana this is a widespread and abundant species in Midwestern large, warmwater rivers.

Key Watershed s: Known only from the Tongue River below 12-mile dam and potentially the Lower Yellowstone River, though not documented. Point of Introduction: Tongue River Reservoir. 


\section{Literature Cited}

Allen, J.D. and A. S. Flecker 1993. Biodiversity Conservation in Running Waters. Bioscience 43 Vol 1: 32-43.

Barnhart, C., W. Haag and W.N. Roston . 2008. Adaptations to host infection and larval parasitism in Unionoida. Journal of the N. A. Benthological Soc. 27:2, 370-394

Bauer, G. 1987. Reproductive strategy of the freshwater pearl mussel Margaritifera margaritifera. Journal of Animal Ecology 56: 691-704.

Bogan A.E. 1993. Freshwater bivalve extinctions (Mollusca:Unionoida): a search for causes. American Zoologist, 33, 599-609.

Cvancara, AC. 2005. Illustrated Key to Wyoming’s Freshwater Mussels http://gf.state.wy.us/downloads/pdf/Fish/Mussels_Of_Wyoming.pdf

Cvancara, Alan M. 1983. Aquatic mollusks of North Dakota. North Dakota Geological Survey, Report of Investigation No. 78. Jamestown, ND: Northern Prairie Wildlife Research Center: http://www.npwrc.usgs.gov/resource/inverts/mollusks/index.htm

Clarke, A.H. 1981. The Freshwater Molluscs of Canada. National Museum of Natural Sciences, National Museums of Canada, Ottawa, Canada.

Clarke, A. H. 1973. The freshwater mollusks of the Canadian Interior Basin. Malacologia 13:1509.

Cooper, J.G. 1867. Geographical catalogue of the Mollusca found east of the Rocky Mountains. Bulletin of American Paleontology (231). Paleontological Research Institution Ithaca, New York, U.S.A.

Cordeiro, J. R. 1999. Distribution and habitat of freshwater mussels (Bivalvia: Unionoida: Unionidae) in Colorado. Natural History Inventory of Colorado 19:1-56.

Elrod, M.J. 1901. Collecting shells in Montana. Nautilus 15(8):86-89.

Elrod, M.J. 1902. Collecting shells in Montana. (cont.). Nautilus 15(9):103-104.

Elrod, M.J. 1902. A Biological Reconnaissance in the Vicinity of Flathead Lake. Bull. Univ. of Montana, No.10, Biol. Series \#3, pp.91-180.

Frest, T. J. and E. J. Johannes. 2000. An annotated checklist of Idaho land and freshwater mollusks. Journal of the Idaho Academy of Science 36: 1-51 
Frest, T. J. and E. J. Johannes. 1995. Interior Columbia Basin mollusk species of special concern. Final report to the Interior Columbia Basin Ecosystem Management Project, Walla Walla, WA. Contract \#43-0E00-4-9112. 274 Pp. Plus Appendices.

Gangloff, M. and D. L. Gustafson 2000. The Freshwater Mussels (Bivalvia: Unionoida) of Montana. Central Plains Archaeology 8(1):121-130.

Goforth, R.R, D.M. Stagliano, M. Penskar and J. Cooper. 2001. Biodiversity Analysis of Selected Riparian Ecosystems within a Fragmented Landscape. Report \#2001-06 to the Michigan Department of Environmental Quality, Office of the Great Lakes, 148pp.

Grayson, D.K. 1988. Danger Cave, Last Supper Cave, and Hanging Rock Shelter: the faunas. Anthropological Papers of the American Museum of Natural History 66(1):1-130.

Haag, W. R., and M. L. Warren. 1999. Mantle displays of freshwater mussels elicit attacks from fish. Freshwater Biology 42:35-40.

Henderson, J. 1924. Mollusca of Colorado, Utah, Montana, Idaho and Wyoming Supplement. The University of Colorado Studies 13(1): 65-223.

Henderson, J. 1936. Mollusca of Colorado, Utah, Montana, Idaho and Wyoming Supplement. The University of Colorado Studies 23(2):81-145.

Jackson, D. 1962. editor. Letters of the Lewis and Clark Expedition with Related Documents, 1783-1854, (Urbana: University of Illinois Press, 1962), p. 176.

Kovalak, W.P., S.D. Dennis and J.M. Bates. 1986. Sampling effort required to find rare species of freshwater mussels. Pages 34-45 in B.G. Isom, ed. Rationale for sampling and interpretation of ecological data in the assessment of freshwater ecosystems. American Society for Testing and Material, Special Technical Publication No. 894.

Leff, L.G., J.L. Burch and J.V. Mcarthur. 1990. Spatial distribution, seston removal and potential competitive interactions of the bivalves Corbicula fluminea and Elliptio complanata, in a coastal plain stream. Freshwater Biology 24:409-416.

Lippincott, K. and L. B. Davis 2000. A Prehistoric Freshwater Mussel Collection from the Schmitt Chert Mine Site (24BW559) near Three Forks, Montana. Central Plains Archaeology 8 (1): 130-134.

McGuire, D.L. and D. Marshall. 2001. Current Distribution of the Western Pearl Mussel, Margaritifera falcata, on the Flathead Reservation. Unpublished internal report for the Confederated Salish and Kootenai Tribes, Montana, 7 pp.

Marking, L.L. and T.D. Bills. 1979. Acute effects of silt and sand sedimentation on freshwater mussels. Pages 204-211 in J.L. Rasmussen (ed.). Proceedings of the UMRCC Symposium on Upper Mississippi River Bivalve Mollusks, Rock Island, IL,

Meador, M.R., C.R. Hupp, T.F. Cuffney, and M.E. Gurtz. 1993. Methods for Characterizing 
Stream Habitat as Part of the National Water Quality Assessment Program. USGS Open-file Report 93-408, Raleigh, NC.

Miller, A.C., and B.S. Payne. 1988. The need for quantitative sampling to characterise size demography and density of freshwater mussel communities. American Malacological Bulletin 6(1):49-54.

Miller, A.C. and B.S. Payne. 1993. Qualitative versus quantitative sampling to evaluate population and community characteristics at a large-river mussel bed. American Midland Naturalist 130:133-145

MNHP and MFWP 2006. Montana Natural Heritage Program and Montana Fish Wildlife and Parks. Montana animal species of concern. Helena, MT: MNHP and MFWP 11p. http://mtnhp.org/Reports/2006_MASOC.pdf

MNHP and MFWP 2004. Montana Natural Heritage Program and Montana Fish Wildlife and Parks. Montana animal species of concern. Helena, MT: MNHP and MFWP 11p. http://mtnhp.org/animal/reports/2004_MASOC.pdf

Montana Department of Environmental Quality. 2007. Montana Nonpoint Source Management Plan. Helena, MT: Montana Department of Environmental Quality, Water Quality Planning Bureau, Watershed Protection Section. Accessed 7/16/08b.

NatureServe 2009a. Faber-Langendoen, D., L. Master, J. Nichols, K. Snow, A. Tomaino, R. Bittman, G. Hammerson, B. Heidel, L. Ramsay, and B.Young. Conservation Status Assessments: Methodology for Assigning Ranks. NatureServe, Arlington, VA

NatureServe 2009b. NatureServe Explorer: An Online Encyclopedia of Life [Web Application], Version 7.0. NatureServe, Arlington, Virginia. Available from URL: http://www.natureserve.org/ explorer [Accessed October 2009].

NatureServe 2008. NatureServe Explorer: An Online Encyclopedia of Life [Web Application], Version 7.0. NatureServe, Arlington, Virginia. Available from URL: http://www.natureserve.org/ explorer [Accessed July 2008].

NatureServe 2005. NatureServe Explorer: An Online Encyclopedia of Life [Web Application], Version 7.0. NatureServe, Arlington, Virginia. Available from URL: http://www.natureserve.org/ explorer [Accessed May 2005].

Nedeau, E. J., M. A. Mccollough and B. I. Swartz. 2000. The freshwater mussels of Maine. Maine Department of Inland Fisheries and Wildlife, Augusta, Maine

Neves, R.J. 1993. A state-of-the-unionids address. Pages 1-10 in K.S. Cummings, A.C. Buchanan and L.M. Koch, eds. Conservation and management of freshwater mussels. Proceedings of a symposium, 12-14 October, 1992, St. Louis, Missouri. Upper Mississippi River Conservation Committee, Rock Island, Illinois.

Neves, R.J. and J.C. Widlak. 1987. Habitat ecology of juvenile freshwater mussels (Bivalvia: Unionidae) in a headwater stream in Virginia. Amer. Malacological Bull. 6(2):179-188. 
Payne, B.S., A.C. Miller and R. Whiting. 1997. Designing a riverine mussel survey. Pages 150-156 in K.S. Cummings, A.C. Buchanan, C.A. Mayer and T.J. Naimo, eds. Conservation and management of freshwater mussels II: initiatives for the future. Proceedings of a UMRCC symposium, 16-18 October 1995, St. Louis, Missouri. Upper Mississippi River Conservation Committee, Rock Island, Illinois.

Phillips, I .D., DA Schulz and K. Kirkham. 2009. Western Range Extension For The Black Sandshell (Unionidae: Ligumia Recta [Lamarck, 1819]). Western North American Naturalist 69(2): 251-252.

Pierce, R. and C. Podner. 2006. The Big Blackfoot River Fisheries Restoration Report for 2004 and 2005. Montana Fish Wildlife and Parks, Missoula Montana.

Rosgen, D.L. 1996. A Classification of Natural Rivers. Catena Vol. 22: 169-199. Elsevier Science, B.V. Amsterdam.

Stein, B. A., L. S. Kutner, and J. S. Adams. 2000. Precious heritage: The status of biodiversity in the United States. Oxford University Press. Oxford, UK.

Stober, Q. J. 1972. Distribution and age of Margaritifera margaritifera (L.) in a Madison River (Montana, U.S.A.) mussel bed. Malacologia 11:343-350.

Stagliano, D. 2010. Distribution \& Population Status of Mussels in Eastern Montana: New Findings and Updates on Five Species East of the Divide. Oral Presentation: MT Chapter American Fisheries Society, $43^{\text {rd }}$ Annual Meeting, Bozeman, MT.

Stagliano, D. 2009. Western Pearlshell (Margaritifera falcata) Mussel Distribution \& Status in Montana: Two Years Later, Its Worse Then We Thought! Oral Presentation: MT Chapter American Fisheries Society, 42nd Annual Meeting, Kalispell, MT.

Stagliano, David, M. 2005. Aquatic Community Classification and Ecosystem Diversity in Montana’s Missouri River Watershed. Report to the Bureau of Land Management. Montana Natural Heritage Program, Helena, Montana. 65 pp. plus appendices. http://www.mtnhp.org/reports.asp\#Ecology

Strayer, D.L., S. Claypool, and S.J. Sprague. 1996. Assessing unionid populations with quadrats and timed searches. In K.S. Cummins, A.C. Buchanan, and L.M. Koch (eds.). The conservation and management of freshwater mussels II: initiatives for the future. Upper Mississippi River Conservation Committee, Rock Isalnd Illinois.

Strayer, D.L. 1997. Effects of exotic species on freshwater mollusks in North America. Draft (3 February 1997) report written for the National Native Mussel Conservation Committee. Institute of Ecosystem Studies, Box AB, Millbrook, New York, 12545. 67 pp.

Stein, B. A., L. S. Kutner, and J. S. Adams. 2000. Precious heritage: The status of biodiversity in the United States. Oxford University Press. Oxford, UK. 399pp. 
Stock, A.L. 1996. Habitat and Population Characteristics of the Freshwater Mussel Margaritifera falcata in Nason Creek, Washington. Unpublished MS Thesis, Evergreen State College.

Stone, J., S. Barndt and M. Gangloff. 2004. Spatial distribution and habitat use of the western pearlshell mussel (Margaritifera falcata) in a western Washington stream. Journal of Freshwater Ecology 19(3): 341-352.

Toy, K.A. 1998. Growth, reproduction and habitat preference of the freshwater mussel, Margaritifera falcata in western Washington. Unpublished MS Thesis, University of Washington, Seattle, 84pp.

Turgeon, D.D., J.F. Quinn, Jr., A.E. Bogan, E.V. Coan, F.G. Hochberg, W.G. Lyons, P.M. Mikkelsen, R.J. Neves, C.F.E. Roper, G. Rosenberg, B. Roth, A. Scheltema, F.G. Thompson, M. Vecchione, and J.D. Williams. 1998. Common and scientific names of aquatic invertebrates from the United States and Canada: Mollusks. 2nd Edition. American Fisheries Society Special Publication 26, Bethesda, Maryland: 526 pp.

Vannote, R.L. and G.W. Minshall. 1982. Fluvial processes and local lithology controlling abundance, structure, and composition of mussel beds. Proceedings of the National Academy of Science 79:4103-4107.

Vaughn, C.C. and C.M. Taylor. 1999. Impoundments and the Decline of Freshwater Mussels: a Case Study of an Extinction Gradient. Conservation Biology 13:912-920.

Vaughn, C.C., C.M. Taylor and K.J. Eberhard. 1996. A Comparison of the Effectiveness of Timed Searches vs. Quadrat Sampling in Mussel Surveys. In K.S. Cummins, A.C. Buchanan, and L.M. Koch (eds.). The conservation and management of freshwater mussels II. Upper Mississippi River Cons. Committee, Rock Island Illinois.

Watters, G.T. 1992. Unionids, fishes and the species-area curve. Journal of Biogeography 19:48-49.

Watters, T. 1995. Sediment in Streams. Univerisity of Minnesota Press. 158 pp.

Young, M.R., P.J. Cosgrove, L.C. Hastie and B. Henniger. 2001. A standardised method for assessing the status of freshwater mussels in shallow water. J. Moll. Stud. 67: 395-396. 


\section{Appendix A. Global/State Rank Definitions}




\section{Heritage Program Ranks}

The international network of Natural Heritage Programs employs a standardized ranking system to denote global (range-wide) and state status. Species are assigned numeric ranks ranging from 1 to 5 , reflecting the relative degree to which they are "at-risk". Rank definitions are given below. A number of factors are considered in assigning ranks - the number, size and distribution of known "occurrences" or populations, population trends (if known), habitat sensitivity, and threat. Factors in a species' life history that make it especially vulnerable are also considered (e.g., dependence on a specific pollinator).

Global Rank Definitions (NatureServe 2003)

G1 Critically imperiled because of extreme rarity and/or other factors making it highly vulnerable to extinction

G2 Imperiled because of rarity and/or other factors making it vulnerable to extinction

G3 Vulnerable because of rarity or restricted range and/or other factors, even though it may be abundant at some of its locations

G4 Apparently secure, though it may be quite rare in parts of its range, especially at the periphery

G5 Demonstrably secure, though it may be quite rare in parts of its range, especially at the periphery

T1-5 Infraspecific Taxon (trinomial) — The status of infraspecific taxa (subspecies or varieties) are indicated by a "T-rank" following the species' global rank

\section{State Rank Definitions}

S1 At high risk because of extremely limited and potentially declining numbers, extent and/or habitat, making it highly vulnerable to extirpation in the state

S2 At risk because of very limited and potentially declining numbers, extent and/or habitat, making it vulnerable to extirpation in the state

S3 Potentially at risk because of limited and potentially declining numbers, extent and/or habitat, even though it may be abundant in some areas

S4 Uncommon but not rare (although it may be rare in parts of its range), and usually widespread. Apparently not vulnerable in most of its range, but possibly cause for long-term concern

S5 Common, widespread, and abundant (although it may be rare in parts of its range). Not vulnerable in most of its range

Combination Ranks

G\#G\# or S\#S\# Range Rank-A numeric range rank (e.g., G2G3) used to indicate uncertainty about the exact status of a taxon

Qualifiers

NR Not ranked

Q Questionable taxonomy that may reduce conservation priority-Distinctiveness of this entity as a taxon at the current level is questionable; resolution of this uncertainty may result in change from a species to a subspecies or hybrid, or inclusion of this taxon in another taxon, with the resulting taxon having a lower-priority (numerically higher) conservation status rank 


\section{Appendix B. Statewide Mussel Survey Points}

Species Code: $\quad$ WEPE $=$ Western Pearlshell

FAMU $=$ Fatmucket

PYGR= Giant Floater

BLSA = Black sandshell

WHHE=White Heelsplitter

MAPL $=$ Mapleleaf

Viability Code: A- excellent viability, B-good viability, C-fair population, not viable $>25$ years, $D$-not viable, extirpated within 25 years, E-verified extant, $\mathrm{F}$ absent, failed to find evidence of a population, $\mathrm{H}$ Historical Verified Site, population now absent) . 


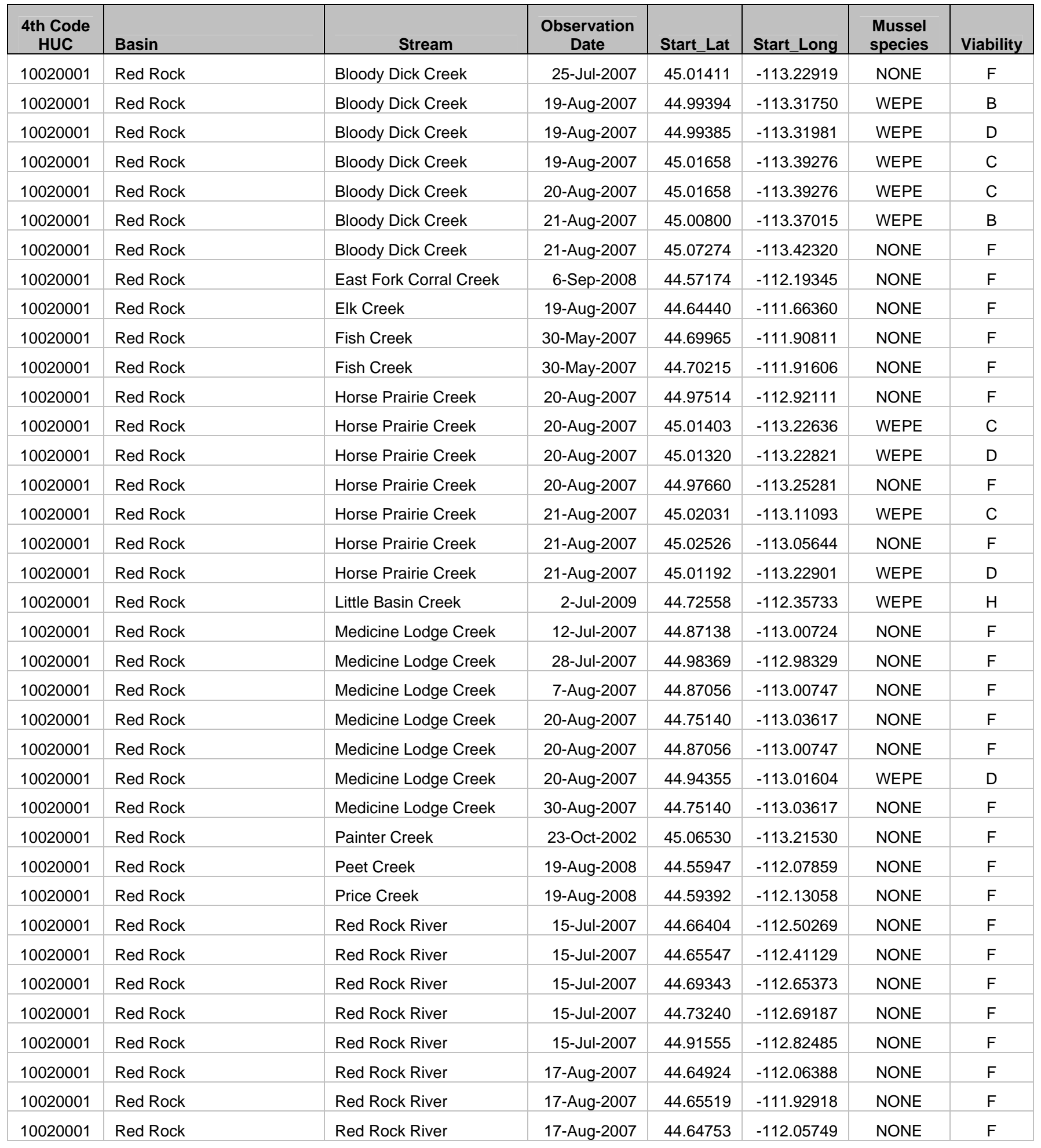




\begin{tabular}{|c|c|c|c|c|c|c|c|}
\hline 10020001 & Red Rock & Red Rock River & 17-Aug-2007 & 44.64759 & -112.08113 & NONE & $\mathrm{F}$ \\
\hline 10020001 & Red Rock & Red Rock River & 20-Aug-2007 & 44.63948 & -112.13846 & NONE & $\mathrm{F}$ \\
\hline 10020001 & Red Rock & Red Rock River & 20-Aug-2007 & 44.64738 & -112.06622 & NONE & $\mathrm{F}$ \\
\hline 10020001 & Red Rock & Red Rock River & 20-Aug-2007 & 44.63854 & -112.13790 & NONE & $\mathrm{F}$ \\
\hline 10020001 & Red Rock & Red Rock River & 20-Aug-2007 & 44.64219 & -111.99532 & NONE & $\mathrm{F}$ \\
\hline 10020001 & Red Rock & Red Rock River & 20-Aug-2007 & 44.64280 & -112.03622 & NONE & $\mathrm{F}$ \\
\hline 10020001 & Red Rock & Red Rock River & 31-Aug-2007 & 44.64738 & -112.06622 & NONE & $\mathrm{F}$ \\
\hline 10020001 & Red Rock & Red Rock River & 31-Aug-2007 & 44.84600 & -112.77220 & NONE & $\mathrm{F}$ \\
\hline 10020001 & Red Rock & Red Rock River & 31-Aug-2007 & 44.84640 & -112.77290 & NONE & $\mathrm{F}$ \\
\hline 10020001 & Red Rock & Red Rock River & 31-Aug-2007 & 44.84700 & -112.77450 & NONE & $\mathrm{F}$ \\
\hline 10020001 & Red Rock & Red Rock River & 19-Aug-2008 & 44.84770 & -112.77780 & NONE & $\mathrm{F}$ \\
\hline 10020001 & Red Rock & Sage Creek & 20-Aug-2007 & 44.73456 & -112.65339 & NONE & $\mathrm{F}$ \\
\hline 10020001 & Red Rock & Selway Creek & 30-Jun-2006 & 45.10271 & -113.41889 & WEPE & $\mathrm{D}$ \\
\hline 10020001 & Red Rock & Selway Creek & 20-Aug-2008 & 45.09291 & -113.23362 & NONE & $\mathrm{F}$ \\
\hline 10020001 & Red Rock & Selway Creek & 20-Aug-2008 & 45.11289 & -113.42200 & WEPE & C \\
\hline 10020001 & Red Rock & Shineberger Creek & 20-Aug-2007 & 44.54544 & -112.42915 & NONE & $\mathrm{F}$ \\
\hline 10020001 & Red Rock & Trail Creek & 21-Aug-2007 & 44.98246 & -113.30718 & NONE & $\mathrm{F}$ \\
\hline 10020001 & Red Rock & Trail Creek & 26-Oct-2009 & 44.98854 & 113.29896 & WEPE & $\mathrm{B}$ \\
\hline 10020001 & Red Rock & Trail Creek & 26-Oct-2009 & 44.98588 & -113.30545 & WEPE & C \\
\hline 10020001 & Red Rock & Trail Creek & 4-Nov-2009 & 44.98298 & 113.30647 & WEPE & C \\
\hline 10020001 & Red Rock & West Fork Price Creek & 7-Sep-2008 & 44.56156 & -112.14018 & NONE & $\mathrm{F}$ \\
\hline 10020001 & Red Rock & West Fork Price Creek & 7-Sep-2008 & 44.56613 & -112.13933 & NONE & $\mathrm{F}$ \\
\hline 10020002 & Beaverhead & Beaverhead River & 19-Aug-2007 & 45.13087 & -112.73960 & WEPE & $\mathrm{D}$ \\
\hline 10020002 & Beaverhead & Beaverhead River & 19-Aug-2007 & 45.10067 & -112.77760 & WEPE & $\mathrm{D}$ \\
\hline 10020002 & Beaverhead & Beaverhead River & 19-Aug-2007 & 45.23484 & -112.62620 & NONE & $\mathrm{F}$ \\
\hline 10020002 & Beaverhead & Beaverhead River & 21-Aug-2007 & 45.09817 & -112.77702 & NONE & $\mathrm{F}$ \\
\hline 10020002 & Beaverhead & Beaverhead River trib & 19-Aug-2007 & 45.13092 & -112.73552 & NONE & $\mathrm{F}$ \\
\hline 10020002 & Beaverhead & Blacktail Deer Creek & 15-Jul-2007 & 45.00528 & -112.44510 & NONE & $\mathrm{F}$ \\
\hline 10020002 & Beaverhead & Cottonwood Creek & 22-Jul-2004 & 44.93326 & -112.45056 & NONE & $\mathrm{F}$ \\
\hline 10020002 & Beaverhead & East Creek & 30-Jun-2006 & 45.10213 & -113.41494 & NONE & $\mathrm{F}$ \\
\hline 10020002 & Beaverhead & Grasshopper Creek & 29-Jun-2007 & 45.23135 & -113.07997 & WEPE & C \\
\hline 10020002 & Beaverhead & Grasshopper Creek & 30-Jun-2007 & 45.28294 & -113.11921 & WEPE & $\mathrm{C}$ \\
\hline 10020002 & Beaverhead & Grasshopper Creek & 25-Jul-2007 & 45.48107 & -113.11014 & WEPE & $\mathrm{H}$ \\
\hline 10020002 & Beaverhead & Grasshopper Creek & 19-Aug-2007 & 45.15978 & -112.98619 & WEPE & $\mathrm{D}$ \\
\hline 10020003 & Ruby & Mill Creek & 15-Jul-2004 & 45.45816 & -112.28003 & NONE & $\mathrm{F}$ \\
\hline 10020003 & Ruby & $\begin{array}{l}\text { North Fork Greenhorn } \\
\text { Creek }\end{array}$ & 15-Jul-2004 & 45.12194 & -112.03920 & NONE & $\mathrm{F}$ \\
\hline 10020003 & Ruby & Ruby River & 13-Aug-2007 & 45.37467 & -112.13815 & NONE & $\mathrm{F}$ \\
\hline 10020004 & Big Hole & Bear Creek & 7-Jul-2005 & 45.59780 & -110.91090 & NONE & $\mathrm{F}$ \\
\hline 10020004 & Big Hole & Bear Creek & 23-Jun-2007 & 45.87715 & -113.06974 & NONE & $\mathrm{F}$ \\
\hline 10020004 & Big Hole & Berry Creek & 14-Sep-2006 & 45.25263 & -113.50551 & NONE & $\mathrm{F}$ \\
\hline 10020004 & Big Hole & Big Hole River & 22-May-2003 & 45.70119 & -112.73618 & NONE & $\mathrm{F}$ \\
\hline 10020004 & Big Hole & Big Hole River & 17-Aug-2005 & 45.62239 & -112.69037 & WEPE & $\mathrm{H}$ \\
\hline 10020004 & Big Hole & Big Hole River & 30-Jun-2007 & 45.31248 & -113.44893 & NONE & $\mathrm{F}$ \\
\hline 10020004 & Big Hole & Big Hole River & 26-Jul-2007 & 45.85939 & -113.08424 & WEPE & $\mathrm{D}$ \\
\hline 10020004 & Big Hole & Big Hole River & 11-Aug-2007 & 45.85972 & -113.08361 & NONE & $\mathrm{F}$ \\
\hline
\end{tabular}




\begin{tabular}{|c|c|c|c|c|c|c|c|}
\hline 10020004 & Big Hole & Big Hole River & 11-Aug-2007 & 45.48913 & -112.69311 & NONE & $\mathrm{F}$ \\
\hline 10020004 & Big Hole & Big Hole River & 19-Aug-2007 & 45.43611 & -113.45875 & NONE & $\mathrm{F}$ \\
\hline 10020004 & Big Hole & Big Hole River & 19-Aug-2007 & 45.88315 & -113.11738 & NONE & $\mathrm{F}$ \\
\hline 10020004 & Big Hole & Big Hole River & 19-Aug-2007 & 45.78636 & -112.91513 & NONE & $\mathrm{F}$ \\
\hline 10020004 & Big Hole & Big Lake Creek & 15-May-1986 & 45.56618 & -113.49272 & NONE & $\mathrm{F}$ \\
\hline 10020004 & Big Hole & Big Lake Creek & 15-May-1986 & 45.44481 & -113.59939 & NONE & $\mathrm{F}$ \\
\hline 10020004 & Big Hole & Bigfoot Creek & 7-Jul-2005 & 46.10724 & -112.13321 & NONE & $\mathrm{F}$ \\
\hline 10020004 & Big Hole & Birch Creek & 13-Aug-2007 & 45.38117 & -112.76881 & NONE & $\mathrm{F}$ \\
\hline 10020004 & Big Hole & Birch Creek & 19-Aug-2007 & 45.38117 & -112.76881 & NONE & $\mathrm{F}$ \\
\hline 10020004 & Big Hole & California Creek & 19-Aug-2007 & 45.95510 & -113.03880 & WEPE & $\mathrm{D}$ \\
\hline 10020004 & Big Hole & Camp Creek & 23-Jul-2005 & 45.65638 & -112.61443 & NONE & $\mathrm{F}$ \\
\hline 10020004 & Big Hole & Canyon Creek & 7-Aug-2006 & 45.62536 & -112.93685 & NONE & $\mathrm{F}$ \\
\hline 10020004 & Big Hole & Canyon Creek & 7-Aug-2006 & 45.67674 & -112.85617 & NONE & $\mathrm{F}$ \\
\hline 10020004 & Big Hole & Chief Joseph Trail Creek & 30-Jun-2007 & 45.64998 & -113.70241 & NONE & $\mathrm{F}$ \\
\hline 10020004 & Big Hole & Chief Joseph Trail Creek & 30-Jun-2007 & 45.65869 & -113.81157 & WEPE & $\mathrm{D}$ \\
\hline 10020004 & Big Hole & Clam Creek & 30-Jun-2006 & 45.79933 & -113.51334 & WEPE & $\mathrm{C}$ \\
\hline 10020004 & Big Hole & Clam Creek & 13-Jul-2009 & 45.80171 & -113.52563 & WEPE & A \\
\hline 10020004 & Big Hole & David Creek & 29-Jun-2007 & 45.53364 & -113.03275 & NONE & $\mathrm{F}$ \\
\hline 10020004 & Big Hole & Deep Creek & 7-Jul-2005 & 45.91183 & -113.11316 & WEPE & B \\
\hline 10020004 & Big Hole & Deno Creek & 28-Jun-2007 & 45.74889 & -113.03010 & NONE & $\mathrm{F}$ \\
\hline 10020004 & Big Hole & Divide Creek & 19-Aug-2007 & 45.75174 & -112.74522 & NONE & $\mathrm{F}$ \\
\hline 10020004 & Big Hole & Doolittle Creek & 19-Jun-2003 & 45.73778 & -113.37944 & NONE & $\mathrm{F}$ \\
\hline 10020004 & Big Hole & Doolittle Creek & 10-Aug-2006 & 45.71780 & -113.34530 & NONE & $\mathrm{F}$ \\
\hline 10020004 & Big Hole & Doolittle Creek & 10-Aug-2006 & 45.71283 & -113.33858 & NONE & $\mathrm{F}$ \\
\hline 10020004 & Big Hole & Doolittle Creek & 19-Jul-2007 & 45.71749 & -113.35008 & NONE & $\mathrm{F}$ \\
\hline 10020004 & Big Hole & Fish Creek & 13-Sep-2006 & 45.79925 & -112.40001 & NONE & $\mathrm{F}$ \\
\hline 10020004 & Big Hole & Fishtrap Creek & 30-Jun-2006 & 45.87000 & -113.22750 & NONE & $\mathrm{F}$ \\
\hline 10020004 & Big Hole & Fourth of July Creek & 28-Jun-2007 & 45.65883 & -113.06054 & NONE & $\mathrm{F}$ \\
\hline 10020004 & Big Hole & Fox Creek & 30-Jun-2006 & 45.27194 & -112.35861 & NONE & $\mathrm{F}$ \\
\hline 10020004 & Big Hole & French Creek & 30-Jun-2006 & 45.94090 & -113.07420 & WEPE & $\mathrm{C}$ \\
\hline 10020004 & Big Hole & French Creek & 30-Jun-2006 & 45.91520 & -113.10600 & WEPE & $\mathrm{C}$ \\
\hline 10020004 & Big Hole & Gold Creek & 23-Jul-2006 & 45.61560 & -113.08420 & NONE & $\mathrm{F}$ \\
\hline 10020004 & Big Hole & Govenour Creek & 30-Jun-2007 & 45.35115 & -113.40926 & WEPE & $\mathrm{D}$ \\
\hline 10020004 & Big Hole & Grouse Creek & 28-Jun-2007 & 45.68259 & -113.07309 & NONE & $\mathrm{F}$ \\
\hline 10020004 & Big Hole & Grouse Creek & 28-Jun-2007 & 45.68687 & -113.08568 & NONE & $\mathrm{F}$ \\
\hline 10020004 & Big Hole & Happy Creek & 29-Jun-2007 & 45.53477 & -113.07682 & NONE & $\mathrm{F}$ \\
\hline 10020004 & Big Hole & Jackson Creek & 27-Jun-2007 & 45.66056 & -110.84778 & NONE & $\mathrm{F}$ \\
\hline 10020004 & Big Hole & Jacobsen Creek & 1-Sep-2006 & 45.52999 & -113.05441 & NONE & $\mathrm{F}$ \\
\hline 10020004 & Big Hole & Jacobsen Creek & 29-Jun-2007 & 45.53416 & -113.03519 & NONE & $\mathrm{F}$ \\
\hline 10020004 & Big Hole & Jacobsen Creek & 29-Jun-2007 & 45.52754 & -113.07172 & NONE & $\mathrm{F}$ \\
\hline 10020004 & Big Hole & Jacobsen Creek trib\#2 & 29-Jun-2007 & 45.53110 & -113.06364 & NONE & $\mathrm{F}$ \\
\hline 10020004 & Big Hole & Jacobsen Creek trib\#2 & 29-Jun-2007 & 45.53110 & -113.06364 & NONE & $\mathrm{F}$ \\
\hline 10020004 & Big Hole & Jerry Creek & 1-May-1995 & 45.82857 & -112.87694 & NONE & $\mathrm{F}$ \\
\hline 10020004 & Big Hole & Jerry Creek & 6-Sep-2006 & 45.79556 & -112.90165 & NONE & $\mathrm{F}$ \\
\hline 10020004 & Big Hole & LaMarche Creek & 16-Jul-2003 & 45.91080 & -113.21720 & NONE & $\mathrm{F}$ \\
\hline
\end{tabular}




\begin{tabular}{|c|c|c|c|c|c|c|c|}
\hline 10020004 & Big Hole & LaMarche Creek & 23-Jul-2006 & 45.87830 & -113.19860 & NONE & $\mathrm{F}$ \\
\hline 10020004 & Big Hole & Miner Creek & 14-Sep-2006 & 45.33729 & -113.54459 & WEPE & $\mathrm{D}$ \\
\hline 10020004 & Big Hole & Moose Creek & 7-Jul-2005 & 45.71377 & -112.70505 & NONE & $\mathrm{F}$ \\
\hline 10020004 & Big Hole & Moose Creek & 13-Sep-2006 & 45.70042 & -112.73557 & WEPE & $\mathrm{D}$ \\
\hline 10020004 & Big Hole & Moose Creek & 23-Jun-2007 & 45.74373 & -112.67081 & NONE & $\mathrm{F}$ \\
\hline 10020004 & Big Hole & Moose Creek & 19-Aug-2007 & 45.76720 & -112.56764 & NONE & $\mathrm{F}$ \\
\hline 10020004 & Big Hole & Moose Creek & 19-Aug-2007 & 45.74195 & -112.67339 & NONE & $\mathrm{F}$ \\
\hline 10020004 & Big Hole & Moose Creek Spring & 28-Jun-2007 & 45.63366 & -113.07452 & NONE & $\mathrm{F}$ \\
\hline 10020004 & Big Hole & Mussingbrod Creek & 13-Aug-2007 & 45.73220 & -113.57080 & NONE & $\mathrm{F}$ \\
\hline 10020004 & Big Hole & $\begin{array}{l}\text { North Fork Big Hole } \\
\text { River }\end{array}$ & 30-Jun-2007 & 45.64353 & -113.65279 & WEPE & C \\
\hline 10020004 & Big Hole & $\begin{array}{l}\text { North Fork Big Hole } \\
\text { River }\end{array}$ & 30-Jun-2007 & 45.64417 & -113.65194 & WEPE & C \\
\hline 10020004 & Big Hole & $\begin{array}{l}\text { North Fork Big Hole } \\
\text { River }\end{array}$ & 19-Aug-2007 & 45.70528 & -113.45944 & NONE & $\mathrm{F}$ \\
\hline 10020004 & Big Hole & $\begin{array}{l}\text { North Fork Big Hole } \\
\text { River }\end{array}$ & 19-Aug-2007 & 45.64446 & -113.65011 & WEPE & C \\
\hline 10020004 & Big Hole & Odell Creek & 20-Sep-2006 & 45.55906 & -113.20129 & NONE & $\mathrm{F}$ \\
\hline 10020004 & Big Hole & Pattengill Creek & 28-Jun-2007 & 45.68218 & -113.06323 & NONE & $\mathrm{F}$ \\
\hline 10020004 & Big Hole & Pintlar Creek & 1-May-1995 & 45.90720 & -113.48110 & NONE & $\mathrm{F}$ \\
\hline 10020004 & Big Hole & Pintlar Creek & 23-Jun-2005 & 45.90731 & -113.48004 & NONE & $\mathrm{F}$ \\
\hline 10020004 & Big Hole & Prairie Creek & 4-Oct-2008 & 45.73958 & -113.87300 & NONE & $\mathrm{F}$ \\
\hline 10020004 & Big Hole & Ruby Creek & 14-Sep-2001 & 45.54358 & -113.75841 & NONE & $\mathrm{F}$ \\
\hline 10020004 & Big Hole & Seymour Creek & 19-Jul-1993 & 45.99850 & -113.18720 & NONE & $\mathrm{F}$ \\
\hline 10020004 & Big Hole & Seymour Creek & 19-Jul-2006 & 45.98970 & -113.18440 & NONE & $\mathrm{F}$ \\
\hline 10020004 & Big Hole & Sourdough Creek & 27-Jun-2007 & 45.64250 & -111.02944 & NONE & $\mathrm{F}$ \\
\hline 10020004 & Big Hole & Spring Gulch & 26-Jun-2009 & 45.83646 & -112.91764 & NONE & $\mathrm{F}$ \\
\hline 10020004 & Big Hole & Fourth of July Creek & 28-Jun-2007 & 45.65830 & -113.06203 & NONE & $\mathrm{F}$ \\
\hline 10020004 & Big Hole & Steel Creek & 10-Aug-2006 & 45.59906 & -113.34986 & NONE & $\mathrm{F}$ \\
\hline 10020004 & Big Hole & Stine Creek & 28-Jun-2007 & 45.71932 & -113.02850 & NONE & $\mathrm{F}$ \\
\hline 10020004 & Big Hole & Swamp Creek & 23-Jun-2007 & 45.65889 & -113.46972 & NONE & $\mathrm{F}$ \\
\hline 10020004 & Big Hole & Thompson Creek & 13-Jul-2009 & 45.79962 & -113.51193 & WEPE & $\mathrm{C}$ \\
\hline 10020004 & Big Hole & Trail Creek & 30-Jun-2006 & 45.70425 & -113.86631 & WEPE & $\mathrm{B}$ \\
\hline 10020004 & Big Hole & Trail Creek & 23-Jul-2006 & 45.65670 & -113.80940 & WEPE & $\mathrm{C}$ \\
\hline 10020004 & Big Hole & Trail Creek & 12-Aug-2007 & 45.67055 & -113.82670 & NONE & $\mathrm{F}$ \\
\hline 10020004 & Big Hole & Trapper Creek & 15-Sep-2006 & 45.63345 & -112.87835 & NONE & $\mathrm{F}$ \\
\hline 10020004 & Big Hole & Twelvemile Creek & 21-Sep-2006 & 45.97458 & -113.09907 & NONE & $\mathrm{F}$ \\
\hline 10020004 & Big Hole & West Fork Jimmie New & 7-Jul-2005 & 45.83977 & -112.95124 & NONE & $\mathrm{F}$ \\
\hline 10020004 & Big Hole & West Fork Jimmie New & 7-Jul-2005 & 45.83977 & -112.95124 & NONE & $\mathrm{F}$ \\
\hline 10020004 & Big Hole & Willow Creek & 23-Jul-2006 & 45.43810 & -112.74220 & NONE & $\mathrm{F}$ \\
\hline 10020004 & Big Hole & Willow Creek & 7-Jul-2007 & 45.44806 & -112.82777 & NONE & $\mathrm{F}$ \\
\hline 10020004 & Big Hole & Willow Creek & 2-Oct-2008 & 45.44810 & -112.82785 & NONE & $\mathrm{F}$ \\
\hline 10020004 & Big Hole & Wisconsin Creek & 10-Aug-2003 & 45.59850 & -113.34226 & NONE & $\mathrm{F}$ \\
\hline 10020004 & Big Hole & Wisconsin Creek & 16-Jul-2007 & 45.59667 & -113.34027 & NONE & $\mathrm{F}$ \\
\hline 10020004 & Big Hole & Wise River & 1-May-1995 & 45.73461 & -113.01626 & NONE & $\mathrm{F}$ \\
\hline 10020004 & Big Hole & Wise River & 13-Jul-2005 & 45.66396 & -113.06375 & NONE & $\mathrm{F}$ \\
\hline 10020004 & Big Hole & Wise River & 1-Sep-2006 & 45.61068 & -113.09101 & NONE & $\mathrm{F}$ \\
\hline 10020004 & Big Hole & Wise River & 28-Jun-2007 & 45.79310 & -112.95030 & NONE & $\mathrm{F}$ \\
\hline
\end{tabular}




\begin{tabular}{|c|c|c|c|c|c|c|c|}
\hline 10020004 & Big Hole & Wise River & 28-Jun-2007 & 45.54311 & -113.08388 & NONE & $\mathrm{F}$ \\
\hline 10020004 & Big Hole & Wise River & 28-Jun-2007 & 45.79206 & -112.95128 & NONE & $\mathrm{F}$ \\
\hline 10020004 & Big Hole & Wise River & 29-Jun-2007 & 45.61450 & -113.08940 & NONE & $\mathrm{F}$ \\
\hline 10020004 & Big Hole & Wyman Creek & 1-Sep-2006 & 45.54908 & -113.14712 & NONE & $\mathrm{F}$ \\
\hline 10020005 & Jefferson & Baggs Creek & 8-Sep-2006 & 46.39124 & -112.59520 & NONE & $\mathrm{F}$ \\
\hline 10020005 & Jefferson & Beefstraight Creek & 11-Sep-2006 & 45.98114 & -112.83307 & NONE & $\mathrm{F}$ \\
\hline 10020005 & Jefferson & Beefstraight Creek & 11-Sep-2006 & 45.98341 & -112.82820 & NONE & $\mathrm{F}$ \\
\hline 10020005 & Jefferson & Big Pipestone Creek & 13-Aug-2007 & 45.87582 & -112.17989 & NONE & $\mathrm{F}$ \\
\hline 10020005 & Jefferson & Bison Creek & 7-Sep-2006 & 46.25268 & -112.34045 & NONE & $\mathrm{F}$ \\
\hline 10020005 & Jefferson & Fish Creek & 23-Jun-2005 & 45.80618 & -112.37225 & NONE & $\mathrm{F}$ \\
\hline 10020005 & Jefferson & Halfway Creek & 22-Sep-2006 & 45.95483 & -112.29862 & WEPE & $\mathrm{D}$ \\
\hline 10020005 & Jefferson & Hells Canyon Creek & 25-Sep-2006 & 45.65807 & -112.38778 & NONE & $\mathrm{F}$ \\
\hline 10020005 & Jefferson & Jefferson River & 30-Jul-1996 & 45.80350 & -111.75080 & FAMU & $\mathrm{C}$ \\
\hline 10020005 & Jefferson & Jefferson River & 9-Sep-2009 & 45.85087 & -111.96903 & FAMU & $\mathrm{C}$ \\
\hline 10020005 & Jefferson & Jefferson River & 9-Sep-2009 & 45.85087 & -111.96903 & WEPE & $\mathrm{D}$ \\
\hline 10020005 & Jefferson & Jefferson River & 11-Sep-2009 & 45.85849 & -112.01252 & FAMU & $\mathrm{D}$ \\
\hline 10020005 & Jefferson & Jefferson River & 29-Apr-2010 & 45.79809 & -111.74135 & FAMU & $\mathrm{C}$ \\
\hline 10020005 & Jefferson & South Boulder River & 25-Sep-2006 & 45.75975 & -111.95928 & NONE & $\mathrm{F}$ \\
\hline 10020005 & Jefferson & State Creek & 7-Jul-2005 & 46.10048 & -112.14178 & NONE & $\mathrm{F}$ \\
\hline 10020005 & Jefferson & Whitetail Creek & 19-Jul-2005 & 45.96225 & -112.16093 & NONE & $\mathrm{F}$ \\
\hline 10020006 & Boulder & Basin Creek & 1-May-1995 & 46.27460 & -112.26588 & NONE & $\mathrm{F}$ \\
\hline 10020006 & Boulder & Bison Creek & 23-Jun-2005 & 46.25498 & -112.34190 & NONE & $\mathrm{F}$ \\
\hline 10020006 & Boulder & Bison Creek & 22-Aug-2007 & 46.25498 & -112.34190 & NONE & $\mathrm{F}$ \\
\hline 10020006 & Boulder & Bison Creek & 12-Jul-2009 & 46.26025 & -112.32941 & NONE & $\mathrm{F}$ \\
\hline 10020006 & Boulder & Boulder River & 7-Sep-2006 & 45.87071 & -111.94280 & WEPE & $\mathrm{D}$ \\
\hline 10020006 & Boulder & Boulder River & 6-Aug-2007 & 45.96992 & -111.88973 & NONE & $\mathrm{H}$ \\
\hline 10020006 & Boulder & Boulder River & 6-Aug-2007 & 46.11356 & -111.91930 & NONE & $\mathrm{F}$ \\
\hline 10020006 & Boulder & Boulder River & 6-Aug-2007 & 46.17734 & -112.03230 & NONE & $\mathrm{F}$ \\
\hline 10020006 & Boulder & Boulder River & 6-Aug-2007 & 46.26231 & -112.34271 & NONE & $\mathrm{F}$ \\
\hline 10020006 & Boulder & Boulder River & 22-Aug-2007 & 46.25427 & -112.47239 & NONE & $\mathrm{F}$ \\
\hline 10020006 & Boulder & Boulder River & 12-Jul-2009 & 46.26041 & -112.32987 & WEPE & $\mathrm{C}$ \\
\hline 10020006 & Boulder & Boulder River & 12-Jul-2009 & 46.26041 & -112.32987 & WEPE & $\mathrm{D}$ \\
\hline 10020006 & Boulder & Elkhorn Creek & 15-Jul-2007 & 46.25127 & -111.96381 & NONE & $\mathrm{F}$ \\
\hline 10020006 & Boulder & High Ore Creek & 23-Jul-2005 & 46.28066 & -112.20274 & NONE & $\mathrm{F}$ \\
\hline 10020006 & Boulder & Little Boulder Creek & 6-Aug-2007 & 46.20042 & -112.09353 & NONE & $\mathrm{F}$ \\
\hline 10020006 & Boulder & Little Boulder River & 2-Oct-2008 & 46.17040 & -112.20250 & NONE & $\mathrm{F}$ \\
\hline 10020006 & Boulder & Muskrat Creek & 23-Jul-2005 & 46.22863 & -112.09052 & NONE & $\mathrm{F}$ \\
\hline 10020006 & Boulder & Muskrat Creek & 6-Aug-2007 & 46.26495 & -112.08293 & NONE & $\mathrm{F}$ \\
\hline 10020006 & Boulder & Muskrat Creek & 22-Aug-2007 & 46.28189 & -112.07314 & NONE & $\mathrm{F}$ \\
\hline 10020006 & Boulder & Muskrat Creek & 22-Aug-2007 & 46.30613 & -112.02909 & NONE & $\mathrm{F}$ \\
\hline 10020006 & Boulder & Red Rock Creek & 5-Sep-1997 & 46.27610 & -112.33050 & NONE & $\mathrm{F}$ \\
\hline 10020006 & Boulder & Rock Creek & 28-Jun-2008 & 46.25775 & -112.50317 & NONE & $\mathrm{F}$ \\
\hline 10020006 & Boulder & Rock Creek & 28-Jun-2008 & 46.26149 & -112.51865 & NONE & $\mathrm{F}$ \\
\hline 10020006 & Boulder & Swamp Creek & 15-Jul-2007 & 45.60209 & -113.55934 & NONE & $\mathrm{F}$ \\
\hline 10020007 & Madison & Cabin Creek & 29-Jul-2007 & 44.87640 & -111.34560 & NONE & $\mathrm{F}$ \\
\hline
\end{tabular}




\begin{tabular}{|c|c|c|c|c|c|c|c|}
\hline 10020007 & Madison & Cherry Creek & 14-Jul-2008 & 45.61977 & -111.54643 & NONE & $\mathrm{F}$ \\
\hline 10020007 & Madison & Cherry Creek & 15-Jul-2008 & 45.62191 & -111.54842 & WEPE & $\mathrm{D}$ \\
\hline 10020007 & Madison & Cherry Creek & 15-Jul-2008 & 45.62143 & -111.54659 & WEPE & $\mathrm{D}$ \\
\hline 10020007 & Madison & Cherry Creek & 15-Jul-2008 & 45.62285 & -111.54975 & WEPE & $\mathrm{D}$ \\
\hline 10020007 & Madison & Cougar Creek & 31-Jul-2007 & 44.71508 & -111.11069 & WEPE & C \\
\hline 10020007 & Madison & Duck Creek & 31-Jul-2007 & 44.77958 & -111.11499 & NONE & $\mathrm{F}$ \\
\hline 10020007 & Madison & Duck Creek & 31-Jul-2007 & 44.77998 & -111.11357 & NONE & $\mathrm{F}$ \\
\hline 10020007 & Madison & Duck Creek & 16-Jul-2008 & 44.77956 & -111.11249 & WEPE & B \\
\hline 10020007 & Madison & Elk Creek & 15-Jul-2007 & 45.62670 & -111.41430 & NONE & $\mathrm{F}$ \\
\hline 10020007 & Madison & Fourmile Creek & 15-Jul-2007 & 45.34124 & -110.23215 & NONE & $\mathrm{F}$ \\
\hline 10020007 & Madison & Hot Springs Creek & 15-Jul-2008 & 45.58564 & -111.59409 & NONE & $\mathrm{F}$ \\
\hline 10020007 & Madison & Jack Creek & 15-Jul-2007 & 45.35338 & -111.54909 & NONE & $\mathrm{F}$ \\
\hline 10020007 & Madison & Madison River & 13-Jul-2002 & 44.64702 & -110.93216 & NONE & $\mathrm{F}$ \\
\hline 10020007 & Madison & Madison River & 31-Jul-2007 & 44.66194 & -110.99187 & WEPE & C \\
\hline 10020007 & Madison & Madison River & 31-Jul-2007 & 44.70339 & -111.09805 & WEPE & C \\
\hline 10020007 & Madison & Madison River & 31-Jul-2007 & 44.70484 & -111.09695 & WEPE & C \\
\hline 10020007 & Madison & Madison River & 31-Jul-2007 & 44.65740 & -111.06970 & WEPE & C \\
\hline 10020007 & Madison & Madison River & 31-Jul-2007 & 45.58510 & -111.57629 & NONE & $\mathrm{F}$ \\
\hline 10020007 & Madison & Madison River & 15-Jul-2008 & 45.57462 & -111.59357 & NONE & $\mathrm{F}$ \\
\hline 10020007 & Madison & Madison River & 16-Jul-2008 & 44.77988 & -111.11298 & WEPE & C \\
\hline 10020007 & Madison & Madison River & 16-Jul-2008 & 45.59050 & -111.57620 & WEPE & $\mathrm{C}$ \\
\hline 10020007 & Madison & Madison River & 15-Jul-2008 & 45.59978 & -111.57332 & NONE & $\mathrm{H}$ \\
\hline 10020007 & Madison & Meadow Creek & 15-Jul-2008 & 45.44380 & -111.71891 & NONE & $\mathrm{F}$ \\
\hline 10020007 & Madison & Meadow Creek & 15-Jul-2008 & 45.44259 & -111.71032 & NONE & $\mathrm{F}$ \\
\hline 10020007 & Madison & Middle Fork of West Fork & 7-Aug-2007 & 45.29219 & -111.38807 & NONE & $\mathrm{F}$ \\
\hline 10020007 & Madison & No Man Creek & 29-Jul-1998 & 45.11550 & -111.49810 & NONE & $\mathrm{F}$ \\
\hline 10020007 & Madison & $\begin{array}{l}\text { North Fork Meadow } \\
\text { Creek }\end{array}$ & 14-Jul-2008 & 45.65757 & -111.89389 & NONE & $\mathrm{F}$ \\
\hline 10020007 & Madison & O'dell Spring Creek & 15-Jul-2007 & 45.30711 & -111.73920 & NONE & $\mathrm{F}$ \\
\hline 10020007 & Madison & $\begin{array}{l}\text { South Fork Madison } \\
\text { River }\end{array}$ & 31-Jul-2007 & 44.65752 & -111.15062 & NONE & $\mathrm{F}$ \\
\hline 10020007 & Madison & $\begin{array}{l}\text { South Fork Madison } \\
\text { River }\end{array}$ & 31-Jul-2007 & 44.67870 & -111.19432 & NONE & $\mathrm{F}$ \\
\hline 10020007 & Madison & West Fork Beaver Creek & 29-Jul-2007 & 44.90506 & -111.36955 & NONE & $\mathrm{F}$ \\
\hline 10020007 & Madison & West Fork Beaver Creek & 29-Jul-2007 & 44.90346 & -111.39455 & NONE & $\mathrm{F}$ \\
\hline 10020008 & Gallatin & Beehive Basin & 10-Sep-1996 & 45.28692 & -111.38665 & NONE & $\mathrm{F}$ \\
\hline 10020008 & Gallatin & Bozeman Creek & 1-Aug-2007 & 45.69977 & -111.02751 & NONE & $\mathrm{F}$ \\
\hline 10020008 & Gallatin & $\begin{array}{l}\text { East Fork Grasshopper } \\
\text { Creek }\end{array}$ & 2-Aug-2007 & 46.54322 & -110.74831 & NONE & $\mathrm{F}$ \\
\hline 10020008 & Gallatin & East Gallatin River & 1-Aug-2007 & 45.88219 & -111.24772 & WEPE & $\mathrm{D}$ \\
\hline 10020008 & Gallatin & East Gallatin River & 1-Aug-2007 & 45.87345 & -111.23249 & WEPE & $\mathrm{D}$ \\
\hline 10020008 & Gallatin & East Gallatin River & 1-Aug-2007 & 45.86278 & -111.20226 & WEPE & $\mathrm{D}$ \\
\hline 10020008 & Gallatin & East Gallatin River & 1-Aug-2007 & 45.83885 & -111.16070 & WEPE & $\mathrm{D}$ \\
\hline 10020008 & Gallatin & East Gallatin River & 1-Aug-2007 & 45.82659 & -111.14189 & WEPE & $\mathrm{H}$ \\
\hline 10020008 & Gallatin & East Gallatin River & 1-Aug-2007 & 45.72568 & -111.06629 & WEPE & $\mathrm{E}$ \\
\hline 10020008 & Gallatin & East Gallatin River & 1-Aug-2007 & 45.69916 & -111.02348 & NONE & $\mathrm{H}$ \\
\hline 10020008 & Gallatin & Elkhorn Creek & 28-Jul-2006 & 45.14939 & -111.21942 & NONE & $\mathrm{F}$ \\
\hline 10020008 & Gallatin & Elkhorn Creek & 28-Jul-2006 & 45.14547 & -111.21210 & NONE & $\mathrm{F}$ \\
\hline
\end{tabular}




\begin{tabular}{|c|c|c|c|c|c|c|c|}
\hline 10020008 & Gallatin & Gallatin River & 30-Jul-1991 & 45.07036 & -111.19460 & NONE & $\mathrm{F}$ \\
\hline 10020008 & Gallatin & Gallatin River & 15-Jul-2007 & 45.67107 & -111.20828 & NONE & $\mathrm{F}$ \\
\hline 10020008 & Gallatin & Gallatin River & 15-Jul-2007 & 45.73944 & -111.21866 & NONE & $\mathrm{F}$ \\
\hline 10020008 & Gallatin & Gallatin River & 1-Aug-2007 & 45.73680 & -111.21862 & NONE & $\mathrm{F}$ \\
\hline 10020008 & Gallatin & Gallatin River & 1-Aug-2007 & 45.29858 & -111.20384 & NONE & $\mathrm{F}$ \\
\hline 10020008 & Gallatin & Gallatin River & 1-Aug-2007 & 45.42645 & -111.23251 & NONE & $\mathrm{F}$ \\
\hline 10020008 & Gallatin & Gallatin River & 1-Aug-2007 & 45.28158 & -111.22520 & NONE & $\mathrm{F}$ \\
\hline 10020008 & Gallatin & Gallatin River & 7-Aug-2007 & 45.48485 & -111.27023 & NONE & $\mathrm{F}$ \\
\hline 10020008 & Gallatin & Gallatin River & 27-Aug-2008 & 45.28158 & -111.22520 & NONE & $\mathrm{F}$ \\
\hline 10020008 & Gallatin & Gallatin River & 27-Aug-2008 & 45.05445 & -111.15644 & NONE & $\mathrm{F}$ \\
\hline 10020008 & Gallatin & Grayling Creek & 1-Aug-2007 & 44.80197 & -111.10935 & NONE & $\mathrm{F}$ \\
\hline 10020008 & Gallatin & Grayling Creek & 1-Aug-2007 & 44.85284 & -111.06271 & NONE & $\mathrm{F}$ \\
\hline 10020008 & Gallatin & Middle Fork of West Fork & 30-Jul-1999 & 45.29389 & -111.41312 & NONE & $\mathrm{F}$ \\
\hline 10020008 & Gallatin & Rocky Creek & 29-Aug-2009 & 45.65405 & -110.94317 & NONE & $\mathrm{F}$ \\
\hline 10020008 & Gallatin & $\begin{array}{l}\text { SF West Fork Gallatin } \\
\text { River }\end{array}$ & 30-Jul-1999 & 45.26713 & -111.27164 & NONE & $\mathrm{F}$ \\
\hline 10020008 & Gallatin & Storm Castle Creek & 1-Aug-2007 & 45.43920 & -111.19838 & NONE & $\mathrm{F}$ \\
\hline 10030101 & Upper Missouri & Battle Creek & 23-Jul-2009 & 46.30121 & -110.95022 & NONE & $\mathrm{F}$ \\
\hline 10030101 & Upper Missouri & Canyon Creek trib & 7-Aug-2007 & 46.80616 & -112.24816 & NONE & $\mathrm{F}$ \\
\hline 10030101 & Upper Missouri & Confederate Creek & 2-Apr-1998 & 46.57600 & -111.45300 & NONE & $\mathrm{F}$ \\
\hline 10030101 & Upper Missouri & Crow Creek & 1-May-1995 & 46.25517 & -111.67165 & NONE & $\mathrm{F}$ \\
\hline 10030101 & Upper Missouri & Deep Creek & 2-Apr-1998 & 46.33030 & -111.27400 & WEPE & $\mathrm{D}$ \\
\hline 10030101 & Upper Missouri & Dry Creek & 6-Aug-2007 & 46.26099 & -111.34025 & NONE & $\mathrm{F}$ \\
\hline 10030101 & Upper Missouri & Dry Creek & 6-Aug-2007 & 46.25012 & -111.39715 & WEPE & $\mathrm{H}$ \\
\hline 10030101 & Upper Missouri & Dry Creek & 23-Jul-2009 & 46.23896 & -111.21787 & NONE & $\mathrm{F}$ \\
\hline 10030101 & Upper Missouri & Dry Creek & 23-Jul-2009 & 46.24064 & -111.24630 & NONE & $\mathrm{F}$ \\
\hline 10030101 & Upper Missouri & Dry Creek & 23-Jul-2009 & 46.25038 & -111.27254 & NONE & $\mathrm{F}$ \\
\hline 10030101 & Upper Missouri & Dry Creek & 23-Jul-2009 & 46.23126 & -111.19307 & NONE & $\mathrm{F}$ \\
\hline 10030101 & Upper Missouri & Duck Creek & 2-Apr-1998 & 46.48680 & -111.38650 & NONE & $\mathrm{F}$ \\
\hline 10030101 & Upper Missouri & Duck Creek & 2-Apr-1998 & 46.48350 & -111.35750 & NONE & $\mathrm{F}$ \\
\hline 10030101 & Upper Missouri & Greyson Creek & 23-Jul-2009 & 46.28689 & -111.26069 & NONE & $\mathrm{F}$ \\
\hline 10030101 & Upper Missouri & Hardgrove Creek & 7-Aug-2007 & 47.20906 & -112.27739 & NONE & $\mathrm{F}$ \\
\hline 10030101 & Upper Missouri & Hay Creek & 23-Jul-2009 & 46.24245 & -111.00628 & NONE & $\mathrm{F}$ \\
\hline 10030101 & Upper Missouri & Indian Creek & 3-Apr-1998 & 46.31680 & -111.63182 & NONE & $\mathrm{F}$ \\
\hline 10030101 & Upper Missouri & Indian Creek & 17-Jul-2005 & 46.32790 & -111.61259 & NONE & $\mathrm{F}$ \\
\hline 10030101 & Upper Missouri & Indian Creek & 17-Jul-2005 & 46.31148 & -111.66750 & NONE & $\mathrm{F}$ \\
\hline 10030101 & Upper Missouri & LaMarche Creek & 7-Jul-2005 & 45.87659 & -113.19838 & NONE & $\mathrm{F}$ \\
\hline 10030101 & Upper Missouri & Little Prickly Pear Creek & 7-Aug-2007 & 46.79768 & -112.36914 & NONE & $\mathrm{F}$ \\
\hline 10030101 & Upper Missouri & Little Prickly Pear Creek & 7-Aug-2007 & 46.78749 & -112.40737 & NONE & $\mathrm{F}$ \\
\hline 10030101 & Upper Missouri & Little Prickly Pear Creek & 7-Aug-2007 & 47.00544 & -112.07147 & NONE & $\mathrm{F}$ \\
\hline 10030101 & Upper Missouri & Little Prickly Pear Creek & 31-Aug-2007 & 46.90260 & -112.12404 & NONE & $\mathrm{F}$ \\
\hline 10030101 & Upper Missouri & Little Prickly Pear Creek & 31-Aug-2007 & 46.85569 & -112.17499 & NONE & $\mathrm{F}$ \\
\hline 10030101 & Upper Missouri & Lump Gulch & 23-Jul-2005 & 46.47729 & -112.07694 & NONE & $\mathrm{F}$ \\
\hline 10030101 & Upper Missouri & Medicine Rock Creek & 23-Jul-2005 & 46.92880 & -112.15036 & NONE & $\mathrm{F}$ \\
\hline 10030101 & Upper Missouri & Prickly Pear Creek & 22-Aug-2007 & 46.37769 & -112.03094 & NONE & $\mathrm{F}$ \\
\hline 10030101 & Upper Missouri & Prickly Pear Creek & 22-Aug-2007 & 46.46870 & -111.98316 & NONE & $\mathrm{F}$ \\
\hline
\end{tabular}




\begin{tabular}{|c|c|c|c|c|c|c|c|}
\hline 10030101 & Upper Missouri & Prickly Pear Creek & 22-Aug-2007 & 46.54062 & -111.92699 & NONE & $\mathrm{F}$ \\
\hline 10030101 & Upper Missouri & Prickly Pear Creek & 29-Aug-2009 & 46.59219 & -111.92127 & NONE & $\mathrm{F}$ \\
\hline 10030101 & Upper Missouri & Sixteenmile Creek & 23-Jul-2009 & 46.27159 & -110.80546 & NONE & $\mathrm{F}$ \\
\hline 10030101 & Upper Missouri & Tepee Creek & 9-Oct-2003 & 46.43255 & -111.85840 & NONE & $\mathrm{F}$ \\
\hline 10030102 & Upper Missouri - Dearborn & Dearborn River & 7-Aug-2007 & 47.19912 & -112.09674 & NONE & $\mathrm{F}$ \\
\hline 10030102 & Upper Missouri - Dearborn & Dearborn River & 7-Aug-2007 & 47.21904 & -112.24185 & NONE & $\mathrm{F}$ \\
\hline 10030102 & Upper Missouri - Dearborn & Flat Creek & 7-Aug-2007 & 47.25204 & -112.06489 & NONE & $\mathrm{F}$ \\
\hline 10030102 & Upper Missouri - Dearborn & Hardgrove Creek & 2-Aug-2007 & 47.19125 & -112.31133 & NONE & $\mathrm{F}$ \\
\hline 10030102 & Upper Missouri - Dearborn & Highwood Creek & 25-Jul-2007 & 47.61337 & -110.90017 & NONE & $\mathrm{F}$ \\
\hline 10030102 & Upper Missouri - Dearborn & Highwood Creek & 25-Jul-2007 & 47.49205 & -110.67473 & NONE & $\mathrm{F}$ \\
\hline 10030102 & Upper Missouri - Dearborn & Highwood Creek & 20-Aug-2009 & 47.64220 & -110.93442 & NONE & $\mathrm{F}$ \\
\hline 10030102 & Upper Missouri - Dearborn & Highwood Creek & 20-Aug-2009 & 47.58224 & -110.80608 & NONE & $\mathrm{F}$ \\
\hline 10030102 & Upper Missouri - Dearborn & Shonkin Creek & 19-Aug-2009 & 47.81863 & -110.63383 & NONE & $\mathrm{F}$ \\
\hline 10030102 & Upper Missouri - Dearborn & Shonkin Creek & 26-Aug-2009 & 47.77508 & -110.64989 & PYGR & $\mathrm{D}$ \\
\hline 10030102 & Upper Missouri - Dearborn & Shonkin Creek & 26-Aug-2009 & 47.77955 & -110.64707 & NONE & $\mathrm{F}$ \\
\hline 10030103 & Smith & Beaver Creek & 23-Jul-2006 & 46.74395 & -111.40850 & NONE & $\mathrm{F}$ \\
\hline 10030103 & Smith & Beaver Creek & 23-Jul-2006 & 46.75185 & -111.19135 & NONE & $\mathrm{F}$ \\
\hline 10030103 & Smith & Calf Creek & 15-Jul-2007 & 46.84788 & -110.95653 & NONE & $\mathrm{F}$ \\
\hline 10030103 & Smith & Camas Creek & 30-Aug-2007 & 46.67809 & -111.19502 & NONE & $\mathrm{F}$ \\
\hline 10030103 & Smith & Cottonwood Creek & 25-Jul-2007 & 46.42819 & -110.85550 & NONE & $\mathrm{F}$ \\
\hline 10030103 & Smith & Deep Creek & 2-Aug-2007 & 46.32448 & -111.29467 & NONE & $\mathrm{F}$ \\
\hline 10030103 & Smith & Deep Creek & 6-Aug-2007 & 46.32671 & -111.36874 & WEPE & $\mathrm{D}$ \\
\hline 10030103 & Smith & Deep Creek & 30-Aug-2007 & 46.32755 & -111.27741 & NONE & $\mathrm{F}$ \\
\hline 10030103 & Smith & Deep Creek & 1-Jul-2008 & 47.10639 & -111.27396 & NONE & $\mathrm{F}$ \\
\hline 10030103 & Smith & Deep Creek & 17-Jul-2008 & 46.33202 & -111.26528 & NONE & $\mathrm{F}$ \\
\hline 10030103 & Smith & Eagle Creek & 30-Aug-2007 & 46.82843 & -111.16463 & NONE & $\mathrm{F}$ \\
\hline 10030103 & Smith & Four Mile Creek & 17-Jul-2008 & 46.58714 & -110.79192 & NONE & $\mathrm{F}$ \\
\hline 10030103 & Smith & Four Mile Creek & 17-Jul-2008 & 46.55023 & -110.74573 & NONE & $\mathrm{F}$ \\
\hline 10030103 & Smith & Hound Creek & 7-Aug-2007 & 47.21526 & -111.39342 & NONE & $\mathrm{F}$ \\
\hline 10030103 & Smith & Logging Creek & 13-Jul-2009 & 47.09678 & -111.01477 & NONE & $\mathrm{F}$ \\
\hline 10030103 & Smith & Moose Creek & 20-Aug-2007 & 46.85117 & -110.86066 & NONE & $\mathrm{F}$ \\
\hline 10030103 & Smith & Moose Creek & 20-Aug-2007 & 46.85117 & -110.86066 & NONE & $\mathrm{F}$ \\
\hline 10030103 & Smith & Newlan Creek & 30-Aug-2007 & 46.59156 & -111.04922 & NONE & $\mathrm{F}$ \\
\hline 10030103 & Smith & North Fork Smith River & 2-Aug-2007 & 46.68022 & -110.71337 & NONE & $\mathrm{F}$ \\
\hline 10030103 & Smith & North Fork Smith River & 2-Aug-2007 & 46.64061 & -110.73511 & NONE & $\mathrm{F}$ \\
\hline 10030103 & Smith & North Fork Smith River & 2-Aug-2007 & 46.57097 & -110.85298 & NONE & $\mathrm{H}$ \\
\hline 10030103 & Smith & North Fork Smith River & 2-Aug-2007 & 46.57704 & -110.84342 & NONE & $\mathrm{H}$ \\
\hline 10030103 & Smith & Sheep Creek & 30-Aug-2007 & 46.80755 & -111.15774 & NONE & $\mathrm{F}$ \\
\hline 10030103 & Smith & Sheep Creek & 13-Jul-2009 & 46.76788 & -110.81139 & NONE & $\mathrm{H}$ \\
\hline 10030103 & Smith & Smith River & 20-May-2004 & 46.58843 & -111.05229 & NONE & $\mathrm{F}$ \\
\hline 10030103 & Smith & Smith River & 2-Aug-2007 & 46.80435 & -111.18284 & NONE & $\mathrm{F}$ \\
\hline 10030103 & Smith & Smith River & 7-Aug-2007 & 46.80405 & -111.18423 & NONE & $\mathrm{F}$ \\
\hline 10030103 & Smith & Smith River & 7-Aug-2007 & 46.80629 & -111.18471 & NONE & $\mathrm{F}$ \\
\hline 10030103 & Smith & Smith River & 7-Aug-2007 & 46.79585 & -111.17866 & NONE & $\mathrm{F}$ \\
\hline 10030103 & Smith & Smith River & 7-Aug-2007 & 46.75526 & -111.17185 & NONE & $\mathrm{F}$ \\
\hline
\end{tabular}




\begin{tabular}{|c|c|c|c|c|c|c|c|}
\hline 10030103 & Smith & Smith River & 13-Aug-2007 & 46.75321 & -111.16840 & NONE & $\mathrm{F}$ \\
\hline 10030103 & Smith & Smith River & 13-Aug-2007 & 46.72399 & -111.18249 & NONE & $\mathrm{F}$ \\
\hline 10030103 & Smith & Smith River & 13-Aug-2007 & 46.67544 & -111.14280 & WEPE & D \\
\hline 10030103 & Smith & Smith River & 13-Aug-2007 & 46.58994 & -111.05261 & NONE & $\mathrm{F}$ \\
\hline 10030103 & Smith & Smith River & 30-Aug-2007 & 46.54840 & -111.00908 & NONE & $\mathrm{F}$ \\
\hline 10030103 & Smith & Smith River & 30-Aug-2007 & 46.87099 & -111.27081 & WEPE & $\mathrm{D}$ \\
\hline 10030103 & Smith & Smith River & 30-Aug-2007 & 47.38973 & -111.44749 & NONE & $\mathrm{F}$ \\
\hline 10030103 & Smith & Smith River & 30-Aug-2007 & 47.26159 & -111.42065 & NONE & $\mathrm{F}$ \\
\hline 10030103 & Smith & Smith River & 30-Aug-2007 & 46.67544 & -111.14286 & NONE & $\mathrm{F}$ \\
\hline 10030103 & Smith & Smith River & 30-Aug-2007 & 46.75528 & -111.17185 & NONE & $\mathrm{F}$ \\
\hline 10030103 & Smith & Smith River & 30-Aug-2007 & 46.80385 & -111.18310 & NONE & $\mathrm{F}$ \\
\hline 10030103 & Smith & Smith River & 30-Aug-2007 & 46.84687 & -111.20994 & NONE & $\mathrm{F}$ \\
\hline 10030103 & Smith & Smith River & 30-Aug-2007 & 46.85511 & -111.24734 & NONE & $\mathrm{F}$ \\
\hline 10030103 & Smith & Smith River & 30-Aug-2007 & 46.86925 & -111.27231 & NONE & $\mathrm{F}$ \\
\hline 10030103 & Smith & Smith River & 30-Jun-2008 & 47.09837 & -111.28163 & NONE & $\mathrm{F}$ \\
\hline 10030103 & Smith & Smith River & 30-Jun-2008 & 47.17446 & -111.33173 & NONE & $\mathrm{F}$ \\
\hline 10030103 & Smith & Smith River & 30-Jun-2008 & 47.18183 & -111.33971 & NONE & $\mathrm{F}$ \\
\hline 10030103 & Smith & Smith River & 30-Jun-2008 & 47.32500 & -111.43287 & NONE & $\mathrm{F}$ \\
\hline 10030103 & Smith & Smith River & 1-Jul-2008 & 47.39335 & -111.44975 & NONE & $\mathrm{F}$ \\
\hline 10030103 & Smith & Smith River & 1-Jul-2008 & 47.39335 & -111.44975 & NONE & $\mathrm{F}$ \\
\hline 10030103 & Smith & Smith River & 2-Jul-2008 & 47.39366 & -111.44955 & NONE & $\mathrm{F}$ \\
\hline 10030103 & Smith & Smith River & 2-Jul-2008 & 46.95896 & -111.29864 & WEPE & $\mathrm{D}$ \\
\hline 10030103 & Smith & Smith River & 20-Aug-2009 & 47.39424 & -111.45018 & FAMU & $\mathrm{D}$ \\
\hline 10030103 & Smith & Smith River & 20-Aug-2009 & 47.39424 & -111.45018 & WEPE & $\mathrm{D}$ \\
\hline 10030103 & Smith & Smith River & 20-Aug-2009 & 47.35515 & -111.43721 & NONE & $\mathrm{F}$ \\
\hline 10030103 & Smith & Smith River & 20-Aug-2009 & 47.26035 & -111.42754 & NONE & $\mathrm{F}$ \\
\hline 10030103 & Smith & Smith River tributary & 30-Aug-2007 & 46.58898 & -111.05308 & NONE & $\mathrm{F}$ \\
\hline 10030103 & Smith & South Fork Smith River & 2-Aug-2007 & 46.44657 & -110.93047 & NONE & $\mathrm{F}$ \\
\hline 10030103 & Smith & South Fork Smith River & 7-Aug-2007 & 46.40943 & -110.89134 & NONE & $\mathrm{F}$ \\
\hline 10030103 & Smith & Spring Park Creek & 2-Aug-2007 & 45.47636 & -112.13833 & NONE & $\mathrm{F}$ \\
\hline 10030103 & Smith & Tenderfoot Creek & 2-Aug-2007 & 46.91987 & -110.86907 & NONE & $\mathrm{F}$ \\
\hline 10030103 & Smith & Thompson Gulch & 21-Jul-2004 & 46.60957 & -111.09198 & NONE & $\mathrm{F}$ \\
\hline 10030103 & Smith & Thompson Gulch & 12-Aug-2007 & 46.51630 & -111.21327 & NONE & $\mathrm{F}$ \\
\hline 10030103 & Smith & Trout Creek & 1-Jul-2008 & 47.02774 & -111.29121 & NONE & $\mathrm{F}$ \\
\hline 10030103 & Smith & Trout Creek & 1-Jul-2008 & 47.05357 & -111.27677 & NONE & $\mathrm{F}$ \\
\hline 10030103 & Smith & $\begin{array}{l}\text { Willow Creek NF Smith } \\
\text { River }\end{array}$ & 17-Jul-2008 & 46.56711 & -110.85694 & NONE & $\mathrm{F}$ \\
\hline 10030104 & Sun & Beaver Creek & 1-May-1995 & 47.59559 & -112.75332 & NONE & $\mathrm{F}$ \\
\hline 10030104 & Sun & Beaver Creek & 20-Jul-2004 & 47.55574 & -112.74722 & NONE & $\mathrm{F}$ \\
\hline 10030104 & Sun & Beaver Creek & 20-Jul-2004 & 47.55574 & -112.74722 & NONE & $\mathrm{F}$ \\
\hline 10030104 & Sun & Elk Creek & 1-May-1995 & 47.50237 & -112.36515 & NONE & $\mathrm{F}$ \\
\hline 10030104 & Sun & Elk Creek & 7-Aug-2007 & 47.48527 & -112.38748 & NONE & $\mathrm{F}$ \\
\hline 10030104 & Sun & Elk Creek & 7-Aug-2007 & 47.51894 & -112.30468 & NONE & $\mathrm{F}$ \\
\hline 10030104 & Sun & Ford Creek & 27-Aug-2008 & 47.44166 & -112.66714 & NONE & $F$ \\
\hline 10030104 & Sun & Hogan's Slough & 7-Aug-2007 & 47.50447 & -112.35414 & NONE & $\mathrm{F}$ \\
\hline 10030104 & Sun & Simms Creek & 1-May-1995 & 47.49853 & -111.96067 & NONE & $\mathrm{F}$ \\
\hline
\end{tabular}




\begin{tabular}{|c|c|c|c|c|c|c|c|}
\hline 10030104 & Sun & South Fork Sun River & 3-Aug-1994 & 47.48698 & -112.91821 & NONE & $\mathrm{F}$ \\
\hline 10030104 & Sun & South Fork Sun River & 2-Aug-2007 & 47.49160 & -112.90900 & NONE & $\mathrm{F}$ \\
\hline 10030104 & Sun & South Fork Sun River & 15-Jul-2008 & 47.49160 & -112.90900 & NONE & $\mathrm{F}$ \\
\hline 10030105 & Belt & Belt Creek & 30-Jul-2003 & 47.13531 & -110.94297 & NONE & $\mathrm{F}$ \\
\hline 10030105 & Belt & Belt Creek & 14-Jul-2009 & 47.21249 & -110.93449 & NONE & $\mathrm{F}$ \\
\hline 10030105 & Belt & Belt Creek & 14-Jul-2009 & 47.58215 & -111.03019 & NONE & $\mathrm{F}$ \\
\hline 10030105 & Belt & Belt Creek & 20-Aug-2009 & 47.58505 & -111.03014 & NONE & $\mathrm{F}$ \\
\hline 10030105 & Belt & Belt Creek & 20-Aug-2009 & 47.54275 & -110.88522 & NONE & $\mathrm{F}$ \\
\hline 10030105 & Belt & Dry Fork Belt Creek & 1-May-1995 & 47.04694 & -110.62827 & NONE & $\mathrm{F}$ \\
\hline 10030201 & Two Medicine & $\begin{array}{l}\text { South Fork Two } \\
\text { Medicine Creek }\end{array}$ & 25-Jul-2006 & 48.36150 & -113.24960 & NONE & $\mathrm{F}$ \\
\hline 10030203 & Marias & Dugout Coulee & 19-Aug-2009 & 48.25768 & -110.90423 & PYGR & $\mathrm{D}$ \\
\hline 10030203 & Marias & Marias River & 17-Aug-2009 & 47.92959 & -110.50348 & FAMU & C \\
\hline 10030203 & Marias & Marias River & 17-Aug-2009 & 48.48696 & -112.22648 & NONE & $\mathrm{F}$ \\
\hline 10030203 & Marias & Marias River & 17-Aug-2009 & 48.43197 & -111.91750 & NONE & $\mathrm{F}$ \\
\hline 10030203 & Marias & Marias River & 17-Aug-2009 & 48.38568 & -111.71614 & FAMU & B \\
\hline 10030203 & Marias & Marias River & 17-Aug-2009 & 48.38449 & -111.71776 & FAMU & $\mathrm{C}$ \\
\hline 10030203 & Marias & Marias River & 17-Aug-2009 & 48.38107 & -111.78777 & FAMU & C \\
\hline 10030203 & Marias & Marias River & 17-Aug-2009 & 48.42679 & -111.89053 & NONE & $\mathrm{F}$ \\
\hline 10030203 & Marias & Marias River & 18-Aug-2009 & 48.39287 & -111.66396 & FAMU & C \\
\hline 10030203 & Marias & Marias River & 18-Aug-2009 & 48.38664 & -111.63892 & FAMU & B \\
\hline 10030203 & Marias & Marias River & 18-Aug-2009 & 48.36764 & -111.60393 & FAMU & C \\
\hline 10030203 & Marias & Marias River & 18-Aug-2009 & 48.30691 & -111.09172 & NONE & $\mathrm{F}$ \\
\hline 10030203 & Marias & Marias River & 18-Aug-2009 & 48.29143 & -111.04643 & NONE & $\mathrm{F}$ \\
\hline 10030203 & Marias & Marias River & 18-Aug-2009 & 48.29201 & -111.04896 & FAMU & C \\
\hline 10030203 & Marias & Marias River & 18-Aug-2009 & 48.29201 & -111.04896 & PYGR & $\mathrm{D}$ \\
\hline 10030203 & Marias & Marias River & 18-Aug-2009 & 48.25939 & -110.89213 & FAMU & C \\
\hline 10030203 & Marias & Marias River & 18-Aug-2009 & 48.26624 & -110.84363 & FAMU & $\mathrm{D}$ \\
\hline 10030203 & Marias & Marias River & 18-Aug-2009 & 48.25777 & -110.90318 & FAMU & $\mathrm{D}$ \\
\hline 10030203 & Marias & Marias River & 18-Aug-2009 & 48.25777 & -110.90318 & PYGR & $\mathrm{D}$ \\
\hline 10030203 & Marias & Marias River & 19-Aug-2009 & 47.94194 & -110.54719 & FAMU & B \\
\hline 10030203 & Marias & Marias River & 19-Aug-2009 & 47.94194 & -110.54719 & PYGR & C \\
\hline 10030203 & Marias & Marias River & 19-Aug-2009 & 47.93233 & -110.50923 & FAMU & C \\
\hline 10030203 & Marias & Marias River & 19-Aug-2009 & 47.93233 & -110.50923 & BLSA & C \\
\hline 10030203 & Marias & Marias River & 19-Aug-2009 & 47.93233 & -110.50923 & PYGR & C \\
\hline 10030203 & Marias & Marias River & 19-Aug-2009 & 47.94669 & -110.52729 & FAMU & C \\
\hline 10030203 & Marias & Marias River & 19-Aug-2009 & 47.94417 & -110.51966 & FAMU & B \\
\hline 10030203 & Marias & Marias River & 19-Aug-2009 & 47.94417 & -110.51966 & BLSA & C \\
\hline 10030203 & Marias & Marias River & 19-Aug-2009 & 47.92957 & -110.49021 & NONE & $\mathrm{F}$ \\
\hline 10030203 & Marias & Marias River & 19-Aug-2009 & 47.82459 & -110.64922 & NONE & $\mathrm{F}$ \\
\hline 10030204 & Willow & Willow Creek & 18-Aug-2009 & 48.42889 & -111.29898 & NONE & $\mathrm{F}$ \\
\hline 10030205 & Teton & Deep Creek & 20-Aug-2009 & 47.76947 & -112.20570 & NONE & $\mathrm{F}$ \\
\hline 10030205 & Teton & Deep Creek & 20-Aug-2009 & 47.71280 & -112.38923 & NONE & $\mathrm{F}$ \\
\hline 10030205 & Teton & Deep Creek & 20-Aug-2009 & 47.71928 & -112.59804 & NONE & $\mathrm{F}$ \\
\hline 10030205 & Teton & Teton River & 4-Aug-1998 & 47.87677 & -111.19690 & NONE & $\mathrm{F}$ \\
\hline 10030205 & Teton & Teton River & 15-May-2009 & 47.86507 & -111.67452 & PYGR & C \\
\hline
\end{tabular}




\begin{tabular}{|c|c|c|c|c|c|c|c|}
\hline 10030205 & Teton & Teton River & 19-Aug-2009 & 47.93250 & -110.51484 & NONE & $\mathrm{F}$ \\
\hline 10030205 & Teton & Waldron Creek & 20-Aug-2009 & 47.92423 & -112.80241 & NONE & $\mathrm{F}$ \\
\hline 10040101 & Bullwhacker - Dog & Beaver Creek & 26-Aug-2009 & 48.55376 & -109.76899 & PYGR & $\mathrm{D}$ \\
\hline 10040101 & Bullwhacker - Dog & Beaver Creek & 26-Aug-2009 & 48.55894 & -109.73640 & PYGR & $\mathrm{D}$ \\
\hline 10040101 & Bullwhacker - Dog & Big Sandy Creek & 25-Aug-2009 & 48.55420 & -109.76822 & PYGR & $\mathrm{D}$ \\
\hline 10040101 & Bullwhacker - Dog & Big Sandy Creek & 25-Aug-2009 & 48.45256 & -109.92069 & PYGR & $\mathrm{D}$ \\
\hline 10040101 & Bullwhacker - Dog & Big Sandy Creek & 26-Aug-2009 & 48.32050 & -110.05753 & PYGR & $\mathrm{D}$ \\
\hline 10040101 & Bullwhacker - Dog & Eagle Creek & 14-Jul-2004 & 47.91580 & -110.05580 & FAMU & B \\
\hline 10040101 & Bullwhacker - Dog & Eagle Creek & 14-Jul-2004 & 47.91580 & -110.05580 & BLSA & B \\
\hline 10040101 & Bullwhacker - Dog & Eagle Creek & 14-Jul-2004 & 47.92361 & -109.92848 & NONE & $\mathrm{F}$ \\
\hline 10040101 & Bullwhacker - Dog & Eagle Creek & 14-Jul-2004 & 47.94434 & -109.86244 & NONE & $\mathrm{F}$ \\
\hline 10040101 & Bullwhacker - Dog & Eagle Creek & 3-Sep-2004 & 48.00401 & -109.83084 & NONE & $\mathrm{F}$ \\
\hline 10040101 & Bullwhacker - Dog & Little Sandy Creek & 13-Jul-2004 & 45.93158 & -110.13623 & FAMU & B \\
\hline 10040101 & Bullwhacker - Dog & Little Sandy Creek & 13-Jul-2004 & 45.93158 & -110.13623 & BLSA & $\mathrm{C}$ \\
\hline 10040101 & Bullwhacker - Dog & Little Sandy Creek & 13-Jul-2004 & 45.93158 & -110.13623 & PYGR & C \\
\hline 10040101 & Bullwhacker - Dog & Little Sandy Creek & 13-Jul-2004 & 48.03060 & -110.13374 & NONE & $\mathrm{F}$ \\
\hline 10040101 & Bullwhacker - Dog & Missouri River & 15-Jul-1994 & 47.70414 & -109.75473 & FAMU & $\mathrm{B}$ \\
\hline 10040101 & Bullwhacker - Dog & Missouri River & 15-Jul-1994 & 47.70414 & -109.75473 & BLSA & B \\
\hline 10040101 & Bullwhacker - Dog & Missouri River & 15-Aug-1994 & 48.02888 & -110.13633 & FAMU & B \\
\hline 10040101 & Bullwhacker - Dog & Missouri River & 15-Sep-1994 & 48.02888 & -110.13633 & BLSA & $\mathrm{C}$ \\
\hline 10040101 & Bullwhacker - Dog & Missouri River & 11-Jun-1995 & 48.03286 & -110.14708 & FAMU & C \\
\hline 10040101 & Bullwhacker - Dog & Missouri River & 11-Sep-1998 & 48.03286 & -110.14708 & BLSA & $\mathrm{C}$ \\
\hline 10040101 & Bullwhacker - Dog & Missouri River & 12-Jul-2004 & 48.03286 & -110.14708 & PYGR & $\mathrm{C}$ \\
\hline 10040101 & Bullwhacker - Dog & Missouri River & 12-Jul-2004 & 47.73372 & -109.67900 & FAMU & C \\
\hline 10040101 & Bullwhacker - Dog & Missouri River & 12-Jul-2004 & 47.73372 & -109.67900 & BLSA & C \\
\hline 10040101 & Bullwhacker - Dog & Missouri River & 12-Jul-2004 & 47.92963 & -110.06351 & FAMU & C \\
\hline 10040101 & Bullwhacker - Dog & Missouri River & 12-Jul-2004 & 47.92963 & -110.06351 & BLSA & C \\
\hline 10040101 & Bullwhacker - Dog & Missouri River & 12-Jul-2004 & 47.76273 & -109.89425 & FAMU & C \\
\hline 10040101 & Bullwhacker - Dog & Missouri River & 12-Jul-2004 & 47.76273 & -109.89425 & BLSA & $\mathrm{C}$ \\
\hline 10040101 & Bullwhacker - Dog & Missouri River & 12-Jul-2004 & 47.71517 & -109.83670 & BLSA & $\mathrm{C}$ \\
\hline 10040101 & Bullwhacker - Dog & Missouri River & 12-Jul-2004 & 47.71517 & -109.83670 & FAMU & $\mathrm{D}$ \\
\hline 10040101 & Bullwhacker - Dog & Missouri River & 12-Jul-2004 & 47.78313 & -109.95358 & FAMU & A \\
\hline 10040101 & Bullwhacker - Dog & Missouri River & 13-Jul-2004 & 47.78313 & -109.95358 & BLSA & $\mathrm{C}$ \\
\hline 10040101 & Bullwhacker - Dog & Missouri River & 13-Jul-2004 & 47.78313 & -109.95358 & PYGR & C \\
\hline 10040101 & Bullwhacker - Dog & Missouri River & 14-Jul-2004 & 47.81932 & -110.05019 & FAMU & B \\
\hline 10040101 & Bullwhacker - Dog & Missouri River & 14-Jul-2004 & 47.81932 & -110.05019 & BLSA & C \\
\hline 10040101 & Bullwhacker - Dog & Missouri River & 14-Jul-2004 & 47.73767 & -109.87557 & FAMU & C \\
\hline 10040101 & Bullwhacker - Dog & Missouri River & 14-Jul-2004 & 47.73767 & -109.87557 & BLSA & $\mathrm{C}$ \\
\hline 10040101 & Bullwhacker - Dog & Missouri River & 15-Jul-2004 & 48.03286 & -110.14708 & BLSA & C \\
\hline 10040101 & Bullwhacker - Dog & Missouri River & 15-Jul-2004 & 48.03286 & -110.14708 & PYGR & $\mathrm{C}$ \\
\hline 10040101 & Bullwhacker - Dog & Missouri River & 15-Jul-2004 & 48.03286 & -110.14708 & FAMU & $\mathrm{D}$ \\
\hline 10040101 & Bullwhacker - Dog & Missouri River & 15-Jul-2004 & 48.03129 & -110.13382 & BLSA & $\mathrm{B}$ \\
\hline 10040101 & Bullwhacker - Dog & Missouri River & 15-Jul-2004 & 48.03129 & -110.13382 & FAMU & C \\
\hline 10040101 & Bullwhacker - Dog & Missouri River & 15-Jul-2004 & 47.91539 & -110.05818 & FAMU & $\mathrm{C}$ \\
\hline 10040101 & Bullwhacker - Dog & Missouri River & 15-Jul-2004 & 47.91539 & -110.05818 & BLSA & $\mathrm{C}$ \\
\hline
\end{tabular}




\begin{tabular}{|c|c|c|c|c|c|c|c|}
\hline 10040101 & Bullwhacker - Dog & Missouri River & 15-Jul-2004 & 47.76206 & -109.91104 & BLSA & C \\
\hline 10040101 & Bullwhacker - Dog & Missouri River & 15-Jul-2004 & 47.76206 & -109.91104 & FAMU & $\mathrm{D}$ \\
\hline 10040101 & Bullwhacker - Dog & Missouri River & 15-Jul-2004 & 47.94737 & -110.07987 & FAMU & C \\
\hline 10040101 & Bullwhacker - Dog & Missouri River & 15-Jul-2004 & 47.94737 & -110.07987 & BLSA & C \\
\hline 10040101 & Bullwhacker - Dog & Missouri River & 15-Jul-2004 & 46.33610 & -111.52870 & FAMU & $\mathrm{D}$ \\
\hline 10040101 & Bullwhacker - Dog & Missouri River & 15-Jul-2004 & 48.03320 & -110.23200 & FAMU & C \\
\hline 10040101 & Bullwhacker - Dog & Missouri River & 16-Jul-2004 & 47.82140 & -110.66110 & NONE & $\mathrm{F}$ \\
\hline 10040101 & Bullwhacker - Dog & Missouri River & 16-Jul-2004 & 47.82140 & -110.66110 & NONE & $\mathrm{F}$ \\
\hline 10040101 & Bullwhacker - Dog & Missouri River & 16-Jul-2004 & 48.03320 & -110.22410 & FAMU & C \\
\hline 10040101 & Bullwhacker - Dog & Missouri River & 16-Jul-2004 & 48.03320 & -110.22410 & BLSA & C \\
\hline 10040101 & Bullwhacker - Dog & Missouri River & 16-Jul-2004 & 48.02900 & -103.54570 & FAMU & C \\
\hline 10040101 & Bullwhacker - Dog & Missouri River & 16-Jul-2004 & 48.10860 & -103.71440 & FAMU & $\mathrm{D}$ \\
\hline 10040101 & Bullwhacker - Dog & Missouri River & 8-Aug-2004 & 47.74930 & -108.92920 & FAMU & $\mathrm{C}$ \\
\hline 10040101 & Bullwhacker - Dog & Missouri River & 12-Aug-2004 & 47.74930 & -108.92920 & PYGR & C \\
\hline 10040101 & Bullwhacker - Dog & Missouri River & 23-Jul-2005 & 47.51039 & -107.93101 & FAMU & $\mathrm{D}$ \\
\hline 10040101 & Bullwhacker - Dog & Missouri River & 25-Aug-2006 & 47.95060 & -110.37440 & PYGR & $\mathrm{C}$ \\
\hline 10040101 & Bullwhacker - Dog & Missouri River & 23-Jul-2009 & 48.03109 & -110.23608 & BLSA & B \\
\hline 10040101 & Bullwhacker - Dog & Missouri River & 23-Jul-2009 & 48.03109 & -110.23608 & FAMU & C \\
\hline 10040101 & Bullwhacker - Dog & Missouri River & 23-Jul-2009 & 47.58489 & -111.06042 & FAMU & $\mathrm{D}$ \\
\hline 10040101 & Bullwhacker - Dog & Missouri River & 19-Aug-2009 & 47.19968 & -111.77515 & NONE & $\mathrm{F}$ \\
\hline 10040101 & Bullwhacker - Dog & Missouri River & 19-Aug-2009 & 47.53103 & -111.23493 & NONE & $\mathrm{F}$ \\
\hline 10040101 & Bullwhacker - Dog & Missouri River & 19-Aug-2009 & 47.52901 & -111.23899 & FAMU & C \\
\hline 10040101 & Bullwhacker - Dog & Missouri River & 19-Aug-2009 & 47.82395 & -110.65081 & NONE & $\mathrm{F}$ \\
\hline 10040101 & Bullwhacker - Dog & Missouri River & 20-Aug-2009 & 47.82207 & -110.66054 & FAMU & $\mathrm{D}$ \\
\hline 10040101 & Bullwhacker - Dog & Missouri River & 20-Aug-2009 & 47.82207 & -110.66054 & BLSA & $\mathrm{D}$ \\
\hline 10040101 & Bullwhacker - Dog & Missouri River & 20-Aug-2009 & 47.76065 & -110.89490 & NONE & $\mathrm{F}$ \\
\hline 10040101 & Bullwhacker - Dog & Missouri River & 20-Aug-2009 & 47.27053 & -111.69506 & WEPE & $\mathrm{D}$ \\
\hline 10040101 & Bullwhacker - Dog & Missouri River & 25-Aug-2009 & 46.26529 & -111.48914 & NONE & $\mathrm{F}$ \\
\hline 10040101 & Bullwhacker - Dog & Missouri River & 25-Aug-2009 & 45.93908 & -111.44527 & NONE & $\mathrm{F}$ \\
\hline 10040101 & Bullwhacker - Dog & Missouri River & 26-Aug-2009 & 46.17369 & -111.44527 & NONE & $\mathrm{F}$ \\
\hline 10040102 & Arrow & Arrow Creek & 16-Jul-2004 & 47.71516 & -109.83360 & FAMU & B \\
\hline 10040102 & Arrow & Arrow Creek & 16-Jul-2004 & 47.71516 & -109.83360 & BLSA & $\mathrm{B}$ \\
\hline 10040103 & Judith & Warm Springs Creek & 8-Oct-2008 & 47.20011 & -109.36424 & NONE & $\mathrm{F}$ \\
\hline 10040104 & Fort Peck Reservoir & Bull Creek & 28-Jun-2006 & 47.78119 & -108.93219 & NONE & $\mathrm{F}$ \\
\hline 10040104 & Fort Peck Reservoir & Bull Creek & 3-Jul-2006 & 47.78259 & -108.93918 & NONE & $\mathrm{F}$ \\
\hline 10040104 & Fort Peck Reservoir & Fargo Coulee & 28-Jun-2006 & 47.57830 & -108.81760 & NONE & $\mathrm{F}$ \\
\hline 10040104 & Fort Peck Reservoir & Porcupine Creek & 21-Jul-2000 & 46.87538 & -111.69213 & NONE & $\mathrm{F}$ \\
\hline 10040104 & Fort Peck Reservoir & $\begin{array}{l}\text { South Fork Two Calf } \\
\text { Creek }\end{array}$ & 28-Jun-2006 & 47.63920 & -108.88790 & NONE & $\mathrm{F}$ \\
\hline 10040104 & Fort Peck Reservoir & Two Calf Creek & 28-Jun-2006 & 47.64058 & -108.86688 & NONE & $\mathrm{F}$ \\
\hline 10040104 & Fort Peck Reservoir & Woodhawk Creek & 3-Jul-2006 & 47.74097 & -108.95696 & NONE & $\mathrm{F}$ \\
\hline 10040201 & Musselshell & Musselshell River & 30-Apr-1995 & 46.44779 & -110.17830 & NONE & $\mathrm{F}$ \\
\hline 10040201 & Musselshell & Musselshell River & 25-Sep-1997 & 46.39018 & -109.65420 & NONE & $\mathrm{F}$ \\
\hline 10040201 & Musselshell & Musselshell River & 25-Jul-2007 & 46.31519 & -109.18520 & NONE & $\mathrm{F}$ \\
\hline 10040201 & Musselshell & Musselshell River & 25-Jul-2007 & 46.30876 & -109.19017 & NONE & $\mathrm{F}$ \\
\hline 10040201 & Musselshell & Musselshell River & 25-Jul-2007 & 46.27896 & -108.83310 & NONE & $\mathrm{F}$ \\
\hline
\end{tabular}


Comprehensive Report on the Freshwater Mussels in Montana

\begin{tabular}{|c|c|c|c|c|c|c|c|}
\hline 10040201 & Musselshell & Musselshell River & 25-Jul-2007 & 46.44634 & -108.51272 & FAMU & B \\
\hline 10040201 & Musselshell & Musselshell River & 25-Jul-2007 & 46.42907 & -109.84167 & NONE & $\mathrm{F}$ \\
\hline 10040201 & Musselshell & Musselshell River & 15-May-2008 & 46.29875 & -108.78150 & NONE & $\mathrm{F}$ \\
\hline 10040201 & Musselshell & Musselshell River & 15-May-2008 & 46.29398 & -109.25800 & NONE & $\mathrm{F}$ \\
\hline 10040201 & Musselshell & Musselshell River & 16-Jul-2008 & 46.44650 & -108.51080 & FAMU & C \\
\hline 10040201 & Musselshell & Musselshell River & 16-Jul-2008 & 46.31654 & -109.41853 & NONE & $\mathrm{F}$ \\
\hline 10040201 & Musselshell & Musselshell River & 17-Jul-2008 & 46.31799 & -109.42023 & NONE & $\mathrm{F}$ \\
\hline 10040201 & Musselshell & $\begin{array}{l}\text { North Fork Musselshell } \\
\text { River }\end{array}$ & 17-Jul-2008 & 46.49318 & -110.31645 & NONE & $F$ \\
\hline 10040201 & Musselshell & $\begin{array}{l}\text { North Fork Musselshell } \\
\text { River }\end{array}$ & 17-Jul-2008 & 46.49611 & -110.33483 & NONE & $\mathrm{F}$ \\
\hline 10040201 & Musselshell & $\begin{array}{l}\text { North Fork Musselshell } \\
\text { River }\end{array}$ & 17-Jul-2008 & 46.50640 & -110.35620 & NONE & $\mathrm{F}$ \\
\hline 10040202 & Middle Musselshell & Musselshell River & 25-Jul-2007 & 46.43781 & -108.54028 & NONE & $\mathrm{F}$ \\
\hline 10040202 & Middle Musselshell & Musselshell River & 23-Jul-2009 & 46.42982 & -110.07250 & NONE & $\mathrm{F}$ \\
\hline 10040202 & Middle Musselshell & Musselshell River & 23-Jul-2009 & 46.46745 & -110.22947 & NONE & $\mathrm{F}$ \\
\hline 10040202 & Middle Musselshell & Musselshell River & 23-Jul-2009 & 46.46252 & -110.31819 & NONE & $\mathrm{F}$ \\
\hline 10040202 & Middle Musselshell & Willow Creek & 22-Jul-2009 & 46.57608 & -108.67858 & NONE & $\mathrm{F}$ \\
\hline 10040205 & Lower Musselshell & Crooked Creek & 27-Jun-2006 & 47.44535 & -108.36953 & NONE & $\mathrm{F}$ \\
\hline 10040205 & Lower Musselshell & Crooked Creek & 27-Jun-2006 & 47.46611 & -108.26443 & NONE & $F$ \\
\hline 10040205 & Lower Musselshell & Musselshell River & 1-Oct-1992 & 46.61989 & -107.82091 & FAMU & B \\
\hline 10040205 & Lower Musselshell & Musselshell River & 1-Oct-1992 & 46.61989 & -107.82091 & BLSA & C \\
\hline 10040205 & Lower Musselshell & Musselshell River & 28-Jul-1998 & 46.62150 & -107.82190 & FAMU & C \\
\hline 10040205 & Lower Musselshell & Musselshell River & 28-Jul-1998 & 46.62150 & -107.82190 & BLSA & C \\
\hline 10040205 & Lower Musselshell & Musselshell River & 26-Aug-2001 & 46.62150 & -107.82190 & FAMU & C \\
\hline 10040205 & Lower Musselshell & Musselshell River & 26-Aug-2001 & 46.62150 & -107.82190 & PYGR & C \\
\hline 10040205 & Lower Musselshell & Musselshell River & 26-Jul-2008 & 46.62150 & -107.82190 & FAMU & C \\
\hline 10040205 & Lower Musselshell & Musselshell River & 26-Jul-2008 & 46.62150 & -107.82190 & PYGR & C \\
\hline 10040205 & Lower Musselshell & Musselshell River & 22-Jul-2009 & 46.62150 & -107.82190 & NONE & $\mathrm{F}$ \\
\hline 10050004 & Milk & Dodson Creek & 20-Jul-2004 & 48.37690 & -108.24600 & FAMU & B \\
\hline 10050004 & Milk & Dodson Creek & 20-Jul-2004 & 48.37690 & -108.24600 & BLSA & B \\
\hline 10050004 & Milk & Dodson Creek & 20-Jul-2004 & 48.37690 & -108.24600 & PYGR & C \\
\hline 10050004 & Milk & Little Cottonwood Creek & 17-Sep-2007 & 48.62011 & -107.83021 & NONE & $\mathrm{F}$ \\
\hline 10050004 & Milk & Milk River & 16-Aug-1994 & 48.58420 & -107.71870 & FAMU & C \\
\hline 10050004 & Milk & Milk River & 15-Aug-1996 & 48.58420 & -107.71870 & BLSA & C \\
\hline 10050004 & Milk & Milk River & 19-May-1997 & 48.58420 & -107.71870 & PYGR & C \\
\hline 10050004 & Milk & Milk River & 19-May-1997 & 48.50797 & -107.21832 & FAMU & B \\
\hline 10050004 & Milk & Milk River & 1-Jul-1997 & 48.50797 & -107.21832 & WHHE & B \\
\hline 10050004 & Milk & Milk River & 26-Apr-2002 & 48.39886 & -107.05201 & FAMU & B \\
\hline 10050004 & Milk & Milk River & 21-Jul-2004 & 48.39886 & -107.05201 & WHHE & B \\
\hline 10050004 & Milk & Milk River & 21-Jul-2004 & 48.39886 & -107.05201 & BLSA & C \\
\hline 10050004 & Milk & Milk River & 21-Jul-2004 & 48.37750 & -108.24640 & FAMU & C \\
\hline 10050004 & Milk & Milk River & 21-Jul-2004 & 48.37750 & -108.24640 & BLSA & C \\
\hline 10050004 & Milk & Milk River & 21-Jul-2004 & 48.17809 & -106.62119 & FAMU & C \\
\hline 10050004 & Milk & Milk River & 21-Jun-2005 & 48.17809 & -106.62119 & WHHE & C \\
\hline 10050004 & Milk & Milk River & 21-Jun-2005 & 48.17809 & -106.62119 & BLSA & C \\
\hline 10050004 & Milk & Milk River & 21-Jun-2005 & 48.55320 & -107.57075 & FAMU & C \\
\hline
\end{tabular}




\begin{tabular}{|c|c|c|c|c|c|c|c|}
\hline 10050004 & Milk & Milk River & 21-Jun-2005 & 48.55320 & -107.57075 & BLSA & $\mathrm{C}$ \\
\hline 10050004 & Milk & Milk River & 21-Jun-2005 & 48.07940 & -106.26640 & FAMU & $\mathrm{C}$ \\
\hline 10050004 & Milk & Milk River & 27-Jun-2006 & 48.07940 & -106.26640 & PYGR & C \\
\hline 10050004 & Milk & Milk River & 27-Jun-2006 & 48.07940 & -106.26640 & PYGR & C \\
\hline 10050004 & Milk & Milk River & 27-Jun-2006 & 48.35940 & -106.90510 & PYGR & $\mathrm{C}$ \\
\hline 10050004 & Milk & Milk River & 28-Jul-2006 & 48.50797 & -107.21832 & PYGR & $\mathrm{C}$ \\
\hline 10050004 & Milk & Milk River & 28-Jul-2006 & 48.50797 & -107.21832 & PYGR & $\mathrm{C}$ \\
\hline 10050004 & Milk & Milk River & 28-Jul-2006 & 48.97533 & -110.42364 & NONE & $\mathrm{F}$ \\
\hline 10050004 & Milk & Milk River & 24-Aug-2009 & 48.83806 & -110.16944 & NONE & $\mathrm{F}$ \\
\hline 10050004 & Milk & Milk River & 24-Aug-2009 & 48.59946 & -109.93837 & NONE & $\mathrm{F}$ \\
\hline 10050004 & Milk & Milk River & 24-Aug-2009 & 48.59878 & -109.93696 & NONE & $\mathrm{F}$ \\
\hline 10050004 & Milk & Milk River & 24-Aug-2009 & 48.57521 & -109.75504 & NONE & $\mathrm{F}$ \\
\hline 10050004 & Milk & Milk River & 25-Aug-2009 & 48.56702 & -109.46282 & NONE & $\mathrm{F}$ \\
\hline 10050004 & Milk & Milk River & 25-Aug-2009 & 48.57965 & -109.25673 & NONE & $\mathrm{F}$ \\
\hline 10050004 & Milk & Milk River & 25-Aug-2009 & 48.37750 & -108.24640 & BLSA & C \\
\hline 10050004 & Milk & Milk River & 25-Aug-2009 & 48.37750 & -108.24640 & FAMU & $\mathrm{D}$ \\
\hline 10050004 & Milk & Milk River & 25-Aug-2009 & 48.52413 & -108.85504 & NONE & $\mathrm{F}$ \\
\hline 10050004 & Milk & Milk River & 25-Aug-2009 & 48.99064 & -110.51538 & NONE & $\mathrm{F}$ \\
\hline 10050004 & Milk & Milk River & 25-Aug-2009 & 48.97231 & -110.41674 & NONE & $\mathrm{F}$ \\
\hline 10050004 & Milk & Milk River & 25-Aug-2009 & 48.79949 & -110.13382 & NONE & $\mathrm{F}$ \\
\hline 10050004 & Milk & Milk River & 25-Aug-2009 & 48.06260 & -106.31480 & WHHE & C \\
\hline 10050004 & Milk & Milk River & 25-Aug-2009 & 48.79949 & -110.13454 & NONE & $\mathrm{F}$ \\
\hline 10050004 & Milk & Milk River trib & 24-Aug-2009 & 48.97294 & -110.42139 & NONE & $\mathrm{F}$ \\
\hline 10050004 & Milk & Savoy Creek & 23-Jun-2004 & 48.50670 & -108.53271 & NONE & $\mathrm{F}$ \\
\hline 10050006 & Sage & Little Sage Creek & 18-Sep-2007 & 48.77925 & -110.77267 & NONE & $\mathrm{F}$ \\
\hline 10050006 & Sage & Sage Creek & 24-Aug-2009 & 48.56630 & -110.30215 & NONE & $\mathrm{F}$ \\
\hline 10050007 & Milk & Lodge Creek & 25-Aug-2009 & 48.59418 & -109.21559 & PYGR & $\mathrm{D}$ \\
\hline 10050008 & Battle & Battle Creek & 2-Jul-2004 & 48.63170 & -109.20860 & PYGR & $\mathrm{C}$ \\
\hline 10050008 & Milk & Battle Creek & 2-Jul-2004 & 48.63170 & -109.20860 & FAMU & B \\
\hline 10050008 & Battle & Battle Creek & 2-Jul-2004 & 48.93638 & -109.43122 & PYGR & $\mathrm{C}$ \\
\hline 10050008 & Battle & Battle Creek & 2-Jul-2004 & 48.93638 & -109.43122 & FAMU & $\mathrm{D}$ \\
\hline 10050008 & Battle & Battle Creek & 2-Jul-2004 & 48.88388 & -109.39550 & FAMU & $\mathrm{C}$ \\
\hline 10050008 & Battle & Battle Creek & 2-Jul-2004 & 48.88388 & -109.39550 & PYGR & $\mathrm{D}$ \\
\hline 10050008 & Battle & Battle Creek & 2-Jul-2004 & 48.78739 & -109.30017 & FAMU & C \\
\hline 10050008 & Battle & Battle Creek & 2-Jul-2004 & 48.78739 & -109.30017 & PYGR & C \\
\hline 10050008 & Battle & Battle Creek & 25-Jul-2004 & 48.63170 & -109.20860 & FAMU & C \\
\hline 10050008 & Battle & Battle Creek & 25-Jul-2004 & 48.63170 & -109.20860 & PYGR & C \\
\hline 10050008 & Battle & Battle Creek & 25-Aug-2009 & 48.78739 & -109.30017 & FAMU & $\mathrm{D}$ \\
\hline 10050008 & Battle & Battle Creek & 25-Aug-2009 & 48.59382 & -109.15541 & FAMU & C \\
\hline 10050008 & Battle & Battle Creek & 25-Aug-2009 & 48.59382 & -109.15541 & PYGR & $\mathrm{D}$ \\
\hline 10050008 & Battle & Battle Creek & 25-Aug-2009 & 48.64918 & -109.23155 & FAMU & B \\
\hline 10050008 & Battle & Battle Creek & 25-Aug-2009 & 48.64918 & -109.23155 & PYGR & B \\
\hline 10050008 & Battle & Battle Creek & 25-Aug-2009 & 48.79369 & -109.30642 & PYGR & $\mathrm{D}$ \\
\hline 10050008 & Battle & Battle Creek & 26-Aug-2009 & 48.88368 & -109.39531 & PYGR & $\mathrm{D}$ \\
\hline 10050008 & Battle & Battle Creek & 26-Aug-2009 & 48.88742 & -109.39785 & FAMU & $\mathrm{C}$ \\
\hline
\end{tabular}




\begin{tabular}{|c|c|c|c|c|c|c|c|}
\hline 10050008 & Battle & Battle Creek & 26-Aug-2009 & 48.88742 & -109.39785 & PYGR & C \\
\hline 10050008 & Battle & Hanson Coulee & 23-Jun-2004 & 48.72620 & -109.28780 & NONE & $\mathrm{F}$ \\
\hline 10050008 & Battle & Link Coulee & 2-Jul-2004 & 48.79860 & -109.34104 & NONE & $\mathrm{F}$ \\
\hline 10050009 & Peoples & People's Creek & 20-May-1995 & 48.40780 & -108.38730 & PYGR & D \\
\hline 10050010 & Cottonwood & Black Coulee & 8-Jun-2004 & 48.74526 & -108.21410 & NONE & $\mathrm{F}$ \\
\hline 10050010 & Cottonwood & Black Coulee & 23-Jun-2004 & 48.74561 & -108.21142 & NONE & $\mathrm{F}$ \\
\hline 10050010 & Cottonwood & Black Coulee & 23-Jun-2004 & 48.74170 & -108.18530 & NONE & $\mathrm{F}$ \\
\hline 10050010 & Cottonwood & Buckley Creek & 8-Jun-2004 & 48.87841 & -108.41762 & NONE & $\mathrm{F}$ \\
\hline 10050010 & Cottonwood & Coberg Coulee & 22-Jun-2004 & 48.74122 & -108.21877 & NONE & $\mathrm{F}$ \\
\hline 10050010 & Cottonwood & Coberg Coulee & 22-Jun-2004 & 48.69130 & -108.25560 & NONE & $\mathrm{F}$ \\
\hline 10050010 & Cottonwood & Cottonwood Creek & 22-Jun-2004 & 48.74130 & -108.18110 & NONE & $\mathrm{F}$ \\
\hline 10050010 & Cottonwood & Cottonwood Creek & 22-Jun-2004 & 48.69557 & -108.10194 & NONE & $\mathrm{F}$ \\
\hline 10050010 & Cottonwood & Cottonwood Creek & 22-Jun-2005 & 48.74135 & -108.18218 & NONE & $\mathrm{F}$ \\
\hline 10050010 & Cottonwood & Cowen Coulee & 22-Jun-2004 & 48.87265 & -108.25798 & NONE & $\mathrm{F}$ \\
\hline 10050010 & Cottonwood & Dry Coulee & 23-Jun-2004 & 48.73180 & -108.18610 & NONE & $\mathrm{F}$ \\
\hline 10050010 & Cottonwood & Lemere Coulee & 23-Jun-2004 & 48.71589 & -108.17088 & NONE & $\mathrm{F}$ \\
\hline 10050010 & Cottonwood & $\begin{array}{l}\text { Lemere Coulee mouth to } \\
\text { Cottonwwod }\end{array}$ & 23-Jun-2004 & 48.71940 & -108.16740 & NONE & $\mathrm{F}$ \\
\hline 10050010 & Cottonwood & Murray Coulee & 21-Jun-2004 & 48.89472 & -108.57329 & NONE & $\mathrm{F}$ \\
\hline 10050011 & Whitewater & $\begin{array}{l}\text { East Fork Whitewater } \\
\text { Creek }\end{array}$ & 22-Jul-2004 & 48.78773 & -107.61360 & NONE & $\mathrm{F}$ \\
\hline 10050011 & Whitewater & Police Creek & 22-Jul-2004 & 48.67011 & -105.63192 & NONE & $\mathrm{F}$ \\
\hline 10050011 & Whitewater & Whitewater Creek & 15-Jul-2004 & 48.95661 & -107.85937 & PYGR & C \\
\hline 10050011 & Whitewater & Whitewater Creek & 21-Jul-2004 & 48.60006 & -107.51947 & PYGR & $\mathrm{D}$ \\
\hline 10050013 & Frenchman & Anderson Coulee & 22-Jul-2004 & 48.58610 & -107.24640 & NONE & $\mathrm{F}$ \\
\hline 10050013 & Frenchman & Frenchman Creek & 15-Jul-1996 & 48.85226 & -107.25938 & NONE & $\mathrm{F}$ \\
\hline 10050013 & Frenchman & Frenchman Creek & 11-Jun-1999 & 48.85789 & -107.25507 & FAMU & C \\
\hline 10050013 & Frenchman & Frenchman Creek & 21-Jul-2004 & 48.85789 & -107.25507 & PYGR & C \\
\hline 10050013 & Frenchman & Frenchman Creek & 21-Jul-2004 & 48.75525 & -107.21223 & FAMU & C \\
\hline 10050013 & Frenchman & Frenchman Creek & 21-Jul-2004 & 48.75525 & -107.21223 & PYGR & C \\
\hline 10050013 & Frenchman & Frenchman Creek & 22-Jul-2004 & 48.59904 & -107.25464 & FAMU & C \\
\hline 10050013 & Frenchman & Frenchman Creek & 22-Jul-2004 & 48.59904 & -107.25464 & PYGR & C \\
\hline 10050013 & Frenchman & Frenchman Creek & 22-Jul-2004 & 48.78350 & -107.23740 & PYGR & C \\
\hline 10050013 & Frenchman & Frenchman Creek & 22-Jul-2004 & 48.78350 & -107.23740 & PYGR & $\mathrm{D}$ \\
\hline 10050013 & Frenchman & Peck Coulee & 21-Jul-2004 & 48.85690 & -107.25670 & NONE & $\mathrm{F}$ \\
\hline 10050013 & Frenchman & Peck Coulee & 21-Jul-2004 & 48.90550 & -107.25500 & NONE & $\mathrm{F}$ \\
\hline 10050013 & Frenchman & Poplar Coulee & 20-Jul-2004 & 48.66610 & -107.26170 & NONE & $\mathrm{F}$ \\
\hline 10050013 & Frenchman & Prestige Coulee & 22-Jul-2004 & 48.61390 & -107.28350 & NONE & $\mathrm{F}$ \\
\hline 10050013 & Frenchman & School Section Coulee & 21-Jul-2004 & 48.82427 & -107.22771 & NONE & $\mathrm{F}$ \\
\hline 10050013 & Frenchman & Shed Coulee & 21-Jul-2004 & 48.76880 & -107.22450 & NONE & $\mathrm{F}$ \\
\hline 10050013 & Frenchman & Woody Coulee & 21-Jul-2004 & 48.92080 & -107.27290 & NONE & $\mathrm{F}$ \\
\hline 10050014 & Beaver in Milk River & Big Warm Creek & 30-Jul-2005 & 48.07640 & -108.27830 & PYGR & C \\
\hline 10050014 & Beaver in Milk River & Big Warm Creek & 21-Jun-2007 & 48.03803 & -108.32982 & PYGR & B \\
\hline 10050014 & Beaver in Milk River & First Creek & 15-Jul-2004 & 48.42526 & -107.35988 & NONE & $\mathrm{F}$ \\
\hline 10050014 & Beaver in Milk River & Little Warm Creek & 30-Jul-2005 & 47.98961 & -108.31467 & PYGR & C \\
\hline 10050014 & Beaver in Milk River & Little Warm Creek & 21-Jun-2007 & 47.98535 & -108.32277 & PYGR & C \\
\hline
\end{tabular}




\begin{tabular}{|c|c|c|c|c|c|c|c|}
\hline 10050015 & Rock Creek & Cherry Creek & 22-Jul-2004 & 48.34974 & -106.63325 & NONE & $\mathrm{F}$ \\
\hline 10050015 & Rock Creek & Rock Creek & 5-Jul-2006 & 48.94098 & -106.85495 & PYGR & $\mathrm{C}$ \\
\hline 10050015 & Rock Creek & Rock Creek & 5-Jul-2006 & 48.85463 & -106.92180 & PYGR & $\mathrm{C}$ \\
\hline 10050015 & Rock Creek & Rock Creek & 31-Jul-2007 & 48.85463 & -106.92180 & NONE & $\mathrm{F}$ \\
\hline 10050015 & Rock Creek & Snake Creek & 21-Jul-2004 & 48.74413 & -107.08369 & NONE & $\mathrm{F}$ \\
\hline 10050015 & Rock Creek & Willow Creek & 30-Jul-2005 & 48.57350 & -106.97406 & FAMU & B \\
\hline 10050015 & Rock Creek & Willow Creek & 30-Jul-2005 & 48.57350 & -106.97406 & PYGR & $\mathrm{C}$ \\
\hline 10060001 & Porcupine & $\begin{array}{l}\text { East Fork Little } \\
\text { Porcupine Creek }\end{array}$ & 4-Oct-2008 & 48.44991 & -106.06615 & NONE & $\mathrm{F}$ \\
\hline 10060001 & Porcupine & Little Porcupine Creek & 28-Aug-2003 & 48.14512 & -106.04875 & NONE & $\mathrm{F}$ \\
\hline 10060003 & Poplar & Butte Creek & 21-Jul-2004 & 48.82810 & -105.60120 & NONE & $\mathrm{F}$ \\
\hline 10060003 & Poplar & Cabarett Coulee & 18-Sep-2007 & 48.65575 & -105.48554 & NONE & $\mathrm{F}$ \\
\hline 10060003 & Poplar & East Fork Poplar River & 11-May-1999 & 48.82780 & -105.45140 & PYGR & $\mathrm{C}$ \\
\hline 10060003 & Poplar & Poplar River & 16-Aug-1994 & 48.12300 & -105.19020 & FAMU & $\mathrm{C}$ \\
\hline 10060003 & Poplar & Poplar River & 11-May-1999 & 48.81930 & -105.47440 & PYGR & $\mathrm{D}$ \\
\hline 10060003 & Poplar & Poplar River & 15-Sep-2003 & 48.78367 & -105.44943 & PYGR & $\mathrm{C}$ \\
\hline 10060004 & West Fork Poplar & Butte Creek trib & 21-Jul-2004 & 48.85811 & -105.86930 & NONE & $\mathrm{F}$ \\
\hline 10060005 & Charlie - Little Muddy & Charlie Creek & 13-Aug-2007 & 48.00950 & -104.73330 & NONE & $\mathrm{F}$ \\
\hline 10060005 & Charlie - Little Muddy & Charlie Creek & 13-Aug-2007 & 48.11374 & -104.86108 & NONE & $\mathrm{F}$ \\
\hline 10060005 & Charlie - Little Muddy & East Charlie Creek & 21-Jul-2004 & 47.96711 & -104.69404 & NONE & $\mathrm{F}$ \\
\hline 10060005 & Charlie - Little Muddy & East Shotgun Creek & 20-Sep-2007 & 48.21542 & -104.27939 & PYGR & C \\
\hline 10060005 & Charlie - Little Muddy & West Shotgun Creek & 20-Sep-2007 & 48.24817 & -104.31388 & NONE & $\mathrm{F}$ \\
\hline 10060006 & Big Muddy & Ator Creek & 15-Aug-1996 & 48.74164 & -104.46795 & NONE & $\mathrm{F}$ \\
\hline 10060006 & Big Muddy & Ator Creek & 21-Jun-2007 & 48.73550 & -104.48100 & PYGR & C \\
\hline 10060006 & Big Muddy & Beaver Creek & 9-Oct-2008 & 48.96895 & -104.97828 & NONE & $\mathrm{F}$ \\
\hline 10060006 & Big Muddy & Big Muddy Creek & 16-Aug-1994 & 48.78190 & -104.65654 & NONE & $\mathrm{F}$ \\
\hline 10060006 & Big Muddy & Big Muddy Creek & 3-Oct-1998 & 48.78190 & -104.65654 & PYGR & $\mathrm{D}$ \\
\hline 10060006 & Big Muddy & Big Muddy Creek & 3-Oct-1998 & 48.33120 & -104.59960 & FAMU & C \\
\hline 10060006 & Big Muddy & Big Muddy Creek & 15-Aug-2003 & 48.34170 & -104.59010 & FAMU & C \\
\hline 10060006 & Big Muddy & Big Muddy Creek & 20-Jun-2007 & 48.34170 & -104.59010 & PYGR & C \\
\hline 10060006 & Big Muddy & Big Muddy Creek & 17-Sep-2007 & 48.70880 & -104.47580 & PYGR & C \\
\hline 10060006 & Big Muddy & Big Muddy Creek & 19-Sep-2007 & 48.14550 & -104.08960 & PYGR & $\mathrm{D}$ \\
\hline 10060006 & Big Muddy & Big Muddy Creek & 19-Sep-2007 & 48.70880 & -104.47580 & PYGR & $\mathrm{D}$ \\
\hline 10060006 & Big Muddy & Lake Creek & 18-Sep-2007 & 48.50533 & -104.30171 & NONE & $\mathrm{F}$ \\
\hline 10060006 & Big Muddy & McCoy Creek & 20-Jun-2007 & 48.83783 & -104.59313 & PYGR & C \\
\hline 10060006 & Big Muddy & McCoy Creek & 18-Sep-2007 & 48.83783 & -104.59313 & PYGR & C \\
\hline 10060006 & Big Muddy & Plentywood Creek & 16-Jun-2004 & 48.86940 & -104.76309 & PYGR & C \\
\hline 10060006 & Big Muddy & Plentywood Creek & 20-Jun-2007 & 48.82483 & -104.68535 & PYGR & $\mathrm{C}$ \\
\hline 10060006 & Big Muddy & Plentywood Creek & 20-Jun-2007 & 48.78391 & -104.65979 & NONE & $\mathrm{F}$ \\
\hline 10060006 & Big Muddy & Sand Creek & 18-Sep-2007 & 48.38921 & -104.20747 & NONE & $\mathrm{F}$ \\
\hline 10060006 & Big Muddy & $\begin{array}{l}\text { South Fork Whitetail } \\
\text { Creek }\end{array}$ & 21-Jun-2007 & 48.86905 & -105.16899 & NONE & $\mathrm{F}$ \\
\hline 10060006 & Big Muddy & Whitetail Creek & 15-Aug-1996 & 48.89150 & -105.16380 & NONE & $\mathrm{F}$ \\
\hline 10060006 & Big Muddy & Whitetail Creek & 21-Jun-2007 & 48.90675 & -104.95276 & PYGR & $\mathrm{D}$ \\
\hline 10060006 & Big Muddy & Whitetail Creek & 18-Sep-2007 & 48.90675 & -104.95276 & NONE & $\mathrm{F}$ \\
\hline 10060006 & Big Muddy & Whitetail Creek & 18-Sep-2007 & 48.88691 & -105.10469 & PYGR & $\mathrm{C}$ \\
\hline
\end{tabular}




\begin{tabular}{|c|c|c|c|c|c|c|c|}
\hline 10060006 & Big Muddy & Whitetail Creek & 9-Oct-2008 & 48.90630 & -104.95150 & PYGR & C \\
\hline 10060006 & Big Muddy & $\begin{array}{l}\text { Whitetail Creek } \\
\text { Reservior }\end{array}$ & 15-Aug-1996 & 48.88980 & -105.15930 & PYGR & $\mathrm{C}$ \\
\hline 10060006 & Big Muddy & Wolf Creek & 13-Aug-2007 & 48.58468 & -104.75366 & NONE & $\mathrm{F}$ \\
\hline 10070002 & Upper Yellowstone & Boulder River & 27-Jun-2006 & 45.83389 & -109.93806 & NONE & $\mathrm{F}$ \\
\hline 10070003 & Upper Yellowstone & Shields River & 27-Jun-2006 & 45.95583 & -110.63361 & NONE & $\mathrm{F}$ \\
\hline 10070004 & Upper Yellowstone & Yellowstone River & 17-Sep-2007 & 45.53850 & -110.58100 & NONE & $\mathrm{F}$ \\
\hline 10070004 & Upper Yellowstone & Yellowstone River & 23-Jul-2009 & 45.68131 & -108.66644 & NONE & $\mathrm{F}$ \\
\hline 10070004 & Upper Yellowstone & Yellowstone River & 23-Jul-2009 & 45.65250 & -110.55890 & NONE & $\mathrm{F}$ \\
\hline 10070006 & Clarks Fork Yellowstone & Yellowstone River & 21-Oct-1975 & 45.62140 & -109.23720 & FAMU & B \\
\hline 10070007 & Upper Yellowstone & Yellowstone River & 23-Jul-2009 & 45.68960 & -108.64490 & NONE & $\mathrm{F}$ \\
\hline 10070007 & Upper Yellowstone & Yellowstone River & 23-Jul-2009 & 45.80000 & -108.46670 & NONE & $\mathrm{F}$ \\
\hline 10070007 & Upper Yellowstone & Yellowstone River & 23-Jul-2009 & 45.90360 & -108.31990 & NONE & $\mathrm{F}$ \\
\hline 10070008 & Pryor & Pryor Creek & 4-Jul-2003 & 45.42584 & -108.55526 & NONE & $\mathrm{F}$ \\
\hline 10080010 & Bighorn Lake & Bighorn River & 5-Aug-1992 & 44.75899 & -108.18087 & FAMU & $D$ \\
\hline 10080010 & Bighorn Lake & Crooked Creek & 3-Sep-2008 & 45.06102 & -108.38927 & NONE & $\mathrm{F}$ \\
\hline 10080015 & Bighorn River & Beauvais Creek & 3-Jul-2003 & 45.47694 & -108.00810 & NONE & $\mathrm{F}$ \\
\hline 10080015 & Bighorn River & Bighorn River & 23-Jul-1998 & 46.14570 & -107.46480 & FAMU & $\mathrm{C}$ \\
\hline 10080015 & Bighorn River & Bighorn River & 11-Sep-2009 & 46.14752 & -107.46650 & FAMU & B \\
\hline 10090101 & Upper Tongue River & Tongue River & 11-Aug-1996 & 45.02260 & -106.81140 & PYGR & C \\
\hline 10090101 & Upper Tongue River & Tongue River & 4-Jul-2003 & 44.99661 & -106.88003 & NONE & $\mathrm{F}$ \\
\hline 10090101 & Upper Tongue River & Tongue River & 4-Jul-2003 & 45.41154 & -106.45758 & FAMU & C \\
\hline 10090101 & Upper Tongue River & Tongue River & 13-May-2008 & 45.36678 & -106.49116 & FAMU & $\mathrm{C}$ \\
\hline 10090101 & Upper Tongue River & Tongue River & 13-May-2008 & 45.03030 & -106.81360 & FAMU & $\mathrm{C}$ \\
\hline 10090101 & Upper Tongue River & Tongue River & 21-Jul-2009 & 45.27044 & -106.62432 & NONE & $\mathrm{F}$ \\
\hline 10090101 & Upper Tongue River & Tongue River & 21-Jul-2009 & 45.41117 & -106.45743 & FAMU & $\mathrm{C}$ \\
\hline 10090102 & Lower Tongue River & Little Pumpkin Creek & 21-Jul-2009 & 45.74459 & -105.84949 & NONE & $\mathrm{F}$ \\
\hline 10090102 & Lower Tongue River & Otter Creek & 20-May-2004 & 45.40361 & -106.14226 & NONE & $\mathrm{F}$ \\
\hline 10090102 & Lower Tongue River & Otter Creek & 21-Jul-2009 & 45.59919 & -106.27085 & NONE & $\mathrm{F}$ \\
\hline 10090102 & Lower Tongue River & Tongue River & 19-Jul-1990 & 46.40130 & -105.85750 & FAMU & C \\
\hline 10090102 & Lower Tongue River & Tongue River & 20-Jul-1994 & 46.40130 & -105.85750 & MAPL & $\mathrm{C}$ \\
\hline 10090102 & Lower Tongue River & Tongue River & 17-Aug-1994 & 46.24800 & -105.75170 & FAMU & C \\
\hline 10090102 & Lower Tongue River & Tongue River & 12-Aug-1996 & 46.24800 & -105.75170 & MAPL & $\mathrm{C}$ \\
\hline 10090102 & Lower Tongue River & Tongue River & 12-Aug-1996 & 46.24800 & -105.75170 & FAMU & C \\
\hline 10090102 & Lower Tongue River & Tongue River & 4-Aug-2001 & 46.24800 & -105.75170 & MAPL & $\mathrm{C}$ \\
\hline 10090102 & Lower Tongue River & Tongue River & 4-Aug-2001 & 46.24800 & -105.75170 & FAMU & C \\
\hline 10090102 & Lower Tongue River & Tongue River & 25-Aug-2001 & 46.24800 & -105.75170 & MAPL & $\mathrm{C}$ \\
\hline 10090102 & Lower Tongue River & Tongue River & 25-Aug-2001 & 46.37400 & -105.83350 & FAMU & B \\
\hline 10090102 & Lower Tongue River & Tongue River & 25-Aug-2001 & 45.84000 & -106.22050 & FAMU & $\mathrm{C}$ \\
\hline 10090102 & Lower Tongue River & Tongue River & 25-Aug-2001 & 45.97880 & -106.05650 & FAMU & C \\
\hline 10090102 & Lower Tongue River & Tongue River & 15-Sep-2001 & 46.40130 & -105.85750 & FAMU & $\mathrm{D}$ \\
\hline 10090102 & Lower Tongue River & Tongue River & 15-Sep-2001 & 46.40130 & -105.85750 & FAMU & C \\
\hline 10090102 & Lower Tongue River & Tongue River & 10-Sep-2009 & 46.40311 & -105.85847 & MAPL & B \\
\hline 10090102 & Lower Tongue River & Tongue River & 10-Sep-2009 & 46.40311 & -105.85847 & FAMU & C \\
\hline 10090102 & Lower Tongue River & Tongue River & 10-Sep-2009 & 46.40311 & -105.85847 & PYGR & $\mathrm{D}$ \\
\hline 10090102 & Lower Tongue River & Tooley Creek & 11-Jul-2005 & 45.21646 & -106.26691 & NONE & $\mathrm{F}$ \\
\hline
\end{tabular}




\begin{tabular}{|c|c|c|c|c|c|c|c|}
\hline 10090207 & Powder River & Powder River & 25-Aug-2001 & 45.53583 & -105.33667 & NONE & $\mathrm{F}$ \\
\hline 10090207 & Powder River & Powder River & 14-Jul-2002 & 46.43200 & -105.31381 & NONE & $\mathrm{F}$ \\
\hline 10090207 & Powder River & Powder River & 11-Jul-2005 & 45.05778 & -105.87750 & NONE & $\mathrm{F}$ \\
\hline 10090207 & Powder River & Powder River & 11-Jul-2005 & 45.01280 & -105.90289 & NONE & $\mathrm{F}$ \\
\hline 10090207 & Powder River & Powder River & 11-Jul-2005 & 45.03771 & -105.88085 & NONE & $\mathrm{F}$ \\
\hline 10090207 & Powder River & Powder River & 11-Jul-2005 & 45.10712 & -105.84206 & NONE & $\mathrm{F}$ \\
\hline 10090207 & Powder River & Powder River & 11-Jul-2005 & 45.18940 & -105.75199 & NONE & $\mathrm{F}$ \\
\hline 10090207 & Powder River & Powder River & 11-Jul-2005 & 45.34667 & -105.53329 & NONE & $\mathrm{F}$ \\
\hline 10090207 & Powder River & Powder River & 11-Jul-2005 & 45.22560 & -105.69058 & NONE & $\mathrm{F}$ \\
\hline 10090207 & Powder River & Powder River & 11-Jul-2005 & 45.04160 & -105.88390 & FAMU & C \\
\hline 10090207 & Powder River & Powder River & 11-Jul-2005 & 46.42530 & -105.30640 & NONE & $\mathrm{F}$ \\
\hline 10090207 & Powder River & Powder River & 11-Jul-2005 & 45.05563 & -105.87547 & NONE & $\mathrm{F}$ \\
\hline 10090209 & Lower Powder & Powder River & 9-Sep-2009 & 46.74201 & -105.43189 & NONE & $\mathrm{F}$ \\
\hline 10100001 & LowerYellowstone Sunday & Little Porcupine Creek & 22-Jul-2009 & 46.30393 & -106.57470 & PYGR & B \\
\hline 10100001 & LowerYellowstone Sunday & Little Porcupine Creek & 22-Jul-2009 & 46.30393 & -106.57470 & FAMU & $\mathrm{D}$ \\
\hline 10100001 & LowerYellowstone Sunday & Yellowstone River & 21-Aug-1975 & 46.26450 & -106.69510 & FAMU & $\mathrm{C}$ \\
\hline 10100001 & LowerYellowstone Sunday & Yellowstone River & 21-Aug-1975 & 46.15020 & -107.48080 & FAMU & $\mathrm{C}$ \\
\hline 10100001 & LowerYellowstone Sunday & Yellowstone River & 21-Nov-1975 & 46.42170 & -105.86060 & FAMU & $\mathrm{B}$ \\
\hline 10100001 & LowerYellowstone Sunday & Yellowstone River & 28-Apr-1992 & 46.80459 & -105.29486 & FAMU & C \\
\hline 10100001 & LowerYellowstone Sunday & Yellowstone River & 5-Aug-1992 & 46.28921 & -106.91063 & FAMU & $\mathrm{D}$ \\
\hline 10100001 & LowerYellowstone Sunday & Yellowstone River & 23-Apr-2002 & 46.33210 & -106.08240 & FAMU & C \\
\hline 10100001 & LowerYellowstone Sunday & Yellowstone River & 23-Aug-2005 & 46.31362 & -107.23741 & FAMU & $\mathrm{C}$ \\
\hline 10100001 & LowerYellowstone Sunday & Yellowstone River & 28-Dec-2007 & 46.31362 & -107.23741 & MAPL & $\mathrm{D}$ \\
\hline 10100001 & LowerYellowstone Sunday & Yellowstone River & 28-Dec-2007 & 46.31362 & -107.23741 & FAMU & C \\
\hline 10100001 & LowerYellowstone Sunday & Yellowstone River & 22-Jul-2009 & 46.27550 & -106.67820 & FAMU & $\mathrm{D}$ \\
\hline 10100001 & LowerYellowstone Sunday & Yellowstone River & 23-Jul-2009 & 46.27550 & -106.67820 & NONE & $\mathrm{F}$ \\
\hline 10100001 & LowerYellowstone Sunday & Yellowstone River & 23-Jul-2009 & 46.27550 & -106.46454 & FAMU & $\mathrm{D}$ \\
\hline 10100001 & LowerYellowstone Sunday & Yellowstone River & 8-Sep-2009 & 46.14151 & -107.54722 & NONE & $\mathrm{F}$ \\
\hline 10100001 & LowerYellowstone Sunday & Yellowstone River & 8-Sep-2009 & 46.26610 & -106.69000 & FAMU & $\mathrm{D}$ \\
\hline 10100001 & LowerYellowstone Sunday & Yellowstone River & 8-Sep-2009 & 46.27483 & -106.67767 & NONE & $\mathrm{F}$ \\
\hline 10100001 & LowerYellowstone Sunday & Yellowstone River & 8-Sep-2009 & 46.27550 & -106.67820 & FAMU & $\mathrm{D}$ \\
\hline 10100001 & LowerYellowstone Sunday & Yellowstone River & 8-Sep-2009 & 46.27550 & -106.46454 & FAMU & $\mathrm{D}$ \\
\hline 10100001 & LowerYellowstone Sunday & Yellowstone River & 8-Sep-2009 & 46.42143 & -105.85693 & FAMU & $\mathrm{D}$ \\
\hline 10100001 & LowerYellowstone Sunday & Yellowstone River & 8-Sep-2009 & 46.80408 & -105.29452 & NONE & $\mathrm{F}$ \\
\hline 10100001 & LowerYellowstone Sunday & Yellowstone River & 8-Sep-2009 & 46.14151 & -107.54722 & NONE & $\mathrm{F}$ \\
\hline 10100001 & LowerYellowstone Sunday & Yellowstone River & 9-Sep-2009 & 46.39851 & -105.89412 & FAMU & $\mathrm{C}$ \\
\hline 10100001 & LowerYellowstone Sunday & Yellowstone River & 11-Sep-2009 & 46.27699 & -106.48205 & FAMU & $\mathrm{D}$ \\
\hline 10100001 & LowerYellowstone Sunday & Yellowstone River & 11-Sep-2009 & 46.25499 & -107.34271 & FAMU & $\mathrm{D}$ \\
\hline 10100001 & LowerYellowstone Sunday & Yellowstone River & 11-Sep-2009 & 46.07504 & -107.71953 & NONE & $\mathrm{F}$ \\
\hline 10100002 & Big Porcupine & Big Porcupine Creek & 22-Jul-2009 & 46.36860 & -106.90967 & NONE & $\mathrm{F}$ \\
\hline 10100003 & Rosebud Creek & Rosebud Creek & 22-Jul-2009 & 46.26958 & -106.47753 & NONE & $\mathrm{F}$ \\
\hline 10100003 & Rosebud Creek & Rosebud Creek & 22-Jul-2009 & 46.26197 & -106.47778 & NONE & $\mathrm{F}$ \\
\hline 10100004 & LowerYellowstone & Cottonwood Creek & 1-Jun-2005 & 47.27664 & -104.38071 & NONE & $\mathrm{F}$ \\
\hline 10100004 & LowerYellowstone & Glendive Creek & 10-Sep-2009 & 47.10154 & -104.63605 & NONE & $\mathrm{F}$ \\
\hline 10100004 & LowerYellowstone & Glendive Creek & 12-Sep-2009 & 47.12162 & -104.66456 & NONE & $\mathrm{F}$ \\
\hline
\end{tabular}




\begin{tabular}{|c|c|c|c|c|c|c|c|}
\hline 10100004 & LowerYellowstone & Yellowstone River & 21-Aug-1975 & 47.10500 & -104.71981 & FAMU & $\mathrm{C}$ \\
\hline 10100004 & LowerYellowstone & Yellowstone River & 21-Aug-1975 & 47.67169 & -104.15847 & FAMU & B \\
\hline 10100004 & LowerYellowstone & Yellowstone River & 8-Oct-1991 & 46.85570 & -105.11450 & FAMU & C \\
\hline 10100004 & LowerYellowstone & Yellowstone River & 24-Apr-2002 & 47.28070 & -104.52400 & FAMU & $\mathrm{D}$ \\
\hline 10100004 & LowerYellowstone & Yellowstone River & 25-Apr-2002 & 47.28070 & -104.52400 & FAMU & $\mathrm{D}$ \\
\hline 10100004 & LowerYellowstone & Yellowstone River & 25-Apr-2002 & 47.75790 & -104.05540 & FAMU & $\mathrm{D}$ \\
\hline 10100004 & LowerYellowstone & Yellowstone River & 7-Aug-2002 & 47.57720 & -104.22030 & FAMU & $\mathrm{C}$ \\
\hline 10100004 & LowerYellowstone & Yellowstone River & 6-Sep-2004 & 47.40420 & -104.34727 & FAMU & $\mathrm{C}$ \\
\hline 10100004 & LowerYellowstone & Yellowstone River & 9-Sep-2009 & 46.83625 & -105.14778 & FAMU & $\mathrm{D}$ \\
\hline 10100004 & LowerYellowstone & Yellowstone River & 9-Sep-2009 & 47.28077 & -104.52584 & FAMU & $\mathrm{D}$ \\
\hline 10100004 & LowerYellowstone & Yellowstone River & 9-Sep-2009 & 47.28125 & -104.53061 & NONE & $\mathrm{F}$ \\
\hline 10100004 & LowerYellowstone & Yellowstone River & 9-Sep-2009 & 47.28081 & -104.51803 & NONE & $\mathrm{F}$ \\
\hline 10100004 & LowerYellowstone & Yellowstone River & 9-Sep-2009 & 47.28077 & -104.52584 & NONE & $\mathrm{F}$ \\
\hline 10100004 & LowerYellowstone & Yellowstone River & 10-Sep-2009 & 47.25959 & -104.54076 & FAMU & $\mathrm{D}$ \\
\hline 10100004 & LowerYellowstone & Yellowstone River & 10-Sep-2009 & 47.28468 & -104.51804 & NONE & $\mathrm{F}$ \\
\hline 10100005 & O Fallon & O Fallon Creek & 9-Sep-2009 & 46.83012 & -105.14468 & FAMU & $\mathrm{D}$ \\
\hline 10100005 & O Fallon & O Fallon Creek & 9-Sep-2009 & 46.83012 & -105.14468 & PYGR & $\mathrm{D}$ \\
\hline 10110201 & Upper Little Missouri & Little Beaver Creek & 10-Aug-1991 & 46.03751 & -104.38748 & PYGR & B \\
\hline 10110201 & Upper Little Missouri & Little Beaver Creek & 12-May-1999 & 46.04870 & -104.36920 & FAMU & C \\
\hline 10110201 & Upper Little Missouri & Little Beaver Creek & 12-May-1999 & 46.04870 & -104.36920 & PYGR & $\mathrm{C}$ \\
\hline 10110201 & Upper Little Missouri & Little Beaver Creek & 12-Jul-1999 & 46.20120 & -104.09600 & PYGR & $\mathrm{D}$ \\
\hline 10110201 & Upper Little Missouri & Little Missouri River & 12-Jul-2004 & 45.27566 & -103.64750 & FAMU & $\mathrm{C}$ \\
\hline 10110201 & Upper Little Missouri & Little Missouri River & 21-Jul-2005 & 45.56420 & -103.95310 & FAMU & $\mathrm{C}$ \\
\hline 10110201 & Upper Little Missouri & Little Missouri River & 21-Jul-2005 & 45.46115 & -104.04126 & NONE & $\mathrm{F}$ \\
\hline 10110201 & Upper Little Missouri & Little Missouri River & 5-Jun-2006 & 45.03260 & -104.42520 & PYGR & C \\
\hline 10110202 & Boxelder & Boxelder Creek & 8-Jun-1991 & 45.84480 & -104.14289 & PYGR & $\mathrm{C}$ \\
\hline 10110202 & Boxelder & Boxelder Creek & 6-Aug-1991 & 45.64050 & -104.39360 & PYGR & $\mathrm{D}$ \\
\hline 10110202 & Boxelder & Boxelder Creek & 5-Jul-1994 & 45.68800 & -104.36880 & PYGR & $\mathrm{C}$ \\
\hline 10110202 & Boxelder & Boxelder Creek & 19-Jul-1994 & 45.68800 & -104.36880 & PYGR & $\mathrm{C}$ \\
\hline 10110202 & Boxelder & Boxelder Creek & 14-Jul-2001 & 45.82180 & -104.24210 & PYGR & $\mathrm{C}$ \\
\hline 10110202 & Boxelder & Boxelder Creek & 14-Jun-2004 & 45.82180 & -104.24210 & PYGR & $\mathrm{C}$ \\
\hline 10110204 & Beaver & Beaver Creek & 14-Aug-1996 & 46.73358 & -104.23220 & WHHE & B \\
\hline 10110204 & Beaver & Beaver Creek & 12-Jul-1999 & 46.73358 & -104.23220 & PYGR & $\mathrm{B}$ \\
\hline 10110204 & Beaver & Beaver Creek & 12-Jul-1999 & 46.60046 & -104.13549 & PYGR & B \\
\hline 10110204 & Beaver & Beaver Creek & 12-Jul-1999 & 46.98530 & -104.18680 & PYGR & $\mathrm{C}$ \\
\hline 10110204 & Beaver & Beaver Creek & 27-Jul-2008 & 46.99001 & -104.18382 & PYGR & B \\
\hline 10110204 & Beaver & Beaver Creek & 27-Jul-2008 & 46.99001 & -104.18382 & FAMU & C \\
\hline 17010101 & Upper Kootenai & Dry Creek & 16-Sep-1992 & 48.29565 & -115.84173 & NONE & $\mathrm{F}$ \\
\hline 17010101 & Upper Kootenai & Fisher River & 25-Jul-2007 & 48.36292 & -115.32267 & NONE & $\mathrm{F}$ \\
\hline 17010101 & Upper Kootenai & Fisher River & 25-Jul-2007 & 48.24472 & -115.29077 & NONE & $\mathrm{F}$ \\
\hline 17010101 & Upper Kootenai & Five Mile Creek & 26-Jul-2007 & 48.53498 & -115.20319 & WEPE & A \\
\hline 17010101 & Upper Kootenai & Five Mile Creek & 26-Jul-2007 & 48.53658 & -115.19758 & WEPE & A \\
\hline 17010101 & Upper Kootenai & Fortine Creek & 7-Aug-2007 & 48.60467 & -114.95766 & WEPE & $\mathrm{C}$ \\
\hline 17010101 & Upper Kootenai & Keeler Creek & 11-Aug-1992 & 48.33416 & -115.93868 & NONE & $\mathrm{F}$ \\
\hline 17010101 & Upper Kootenai & Keeler Creek & 17-Sep-1992 & 48.35716 & -115.85899 & NONE & $\mathrm{F}$ \\
\hline
\end{tabular}




\begin{tabular}{|c|c|c|c|c|c|c|c|}
\hline 17010101 & Upper Kootenai & Lake Creek & 25-Jul-2007 & 48.42091 & -115.86332 & NONE & $\mathrm{F}$ \\
\hline 17010101 & Upper Kootenai & Meadow Creek & 23-Jul-2007 & 48.42091 & -115.86332 & NONE & $\mathrm{F}$ \\
\hline 17010101 & Upper Kootenai & Pipe Creek & 25-Jul-2007 & 48.57809 & -115.59150 & NONE & $\mathrm{F}$ \\
\hline 17010101 & Upper Kootenai & Pipe Creek & 25-Jul-2007 & 48.52237 & -115.52825 & NONE & $\mathrm{F}$ \\
\hline 17010101 & Upper Kootenai & Pipe Creek & 25-Jul-2007 & 48.42730 & -115.59665 & NONE & $\mathrm{F}$ \\
\hline 17010101 & Upper Kootenai & Snowshoe Creek & 14-Aug-1992 & 48.20493 & -115.64683 & NONE & $\mathrm{F}$ \\
\hline 17010101 & Upper Kootenai & Snowshoe Creek & 14-Aug-1992 & 48.20721 & -115.64200 & NONE & $\mathrm{F}$ \\
\hline 17010101 & Upper Kootenai & Swamp Creek & 25-Jul-2007 & 48.21829 & -115.46811 & NONE & $\mathrm{F}$ \\
\hline 17010101 & Upper Kootenai & Thompson River & 1-Aug-2007 & 47.71273 & -115.05859 & WEPE & $\mathrm{D}$ \\
\hline 17010101 & Upper Kootenai & Tobacco River & 13-Aug-1992 & 48.89850 & -115.12310 & WEPE & $\mathrm{H}$ \\
\hline 17010102 & Fisher & East Fisher River & 26-Jul-2007 & 47.95641 & -115.32267 & WEPE & A \\
\hline 17010102 & Fisher & East Fisher River & 26-Jul-2007 & 47.95754 & -115.33347 & WEPE & B \\
\hline 17010102 & Fisher & Little Wolf Creek & 26-Jul-2007 & 48.30518 & -115.03511 & NONE & $\mathrm{F}$ \\
\hline 17010102 & Fisher & $\begin{array}{l}\text { Pleasant Valley Fisher } \\
\text { River }\end{array}$ & 26-Jul-2007 & 48.04413 & -115.28385 & WEPE & C \\
\hline 17010102 & Fisher & $\begin{array}{l}\text { Pleasant Valley Fisher } \\
\text { River }\end{array}$ & 26-Aug-2008 & 48.02584 & -115.33896 & NONE & $\mathrm{F}$ \\
\hline 17010102 & Fisher & $\begin{array}{l}\text { Pleasant Valley Fisher } \\
\text { River }\end{array}$ & 26-Aug-2008 & 48.04445 & -115.28459 & NONE & $\mathrm{F}$ \\
\hline 17010102 & Fisher & $\begin{array}{l}\text { Pleasant Valley Fisher } \\
\text { River }\end{array}$ & 26-Aug-2008 & 48.05443 & -115.27847 & NONE & $\mathrm{F}$ \\
\hline 17010102 & Fisher & Slimmer Creek & 26-Jul-2007 & 48.03182 & -115.06092 & WEPE & $\mathrm{D}$ \\
\hline 17010102 & Fisher & Wolf Creek & 26-Jul-2007 & 48.30627 & -115.03677 & NONE & $\mathrm{F}$ \\
\hline 17010102 & Fisher & Wolf Creek & 26-Jul-2007 & 48.26410 & -115.15415 & WEPE & C \\
\hline 17010102 & Fisher & Wolf Creek & 26-Jul-2007 & 48.29862 & -115.04420 & WEPE & C \\
\hline 17010102 & Fisher & Wolf Creek & 26-Jul-2007 & 48.30174 & -115.03806 & WEPE & C \\
\hline 17010103 & Fisher & Basin Creek & 23-Jul-2007 & 48.91220 & -115.47480 & NONE & $\mathrm{F}$ \\
\hline 17010103 & Yaak & Beaver Creek & 23-Jul-2007 & 48.81921 & -115.68125 & NONE & $\mathrm{F}$ \\
\hline 17010103 & Yaak & Beaver Creek & 23-Jul-2007 & 48.82000 & -115.68000 & NONE & $\mathrm{F}$ \\
\hline 17010103 & Yaak & Clay Creek & 23-Jul-2001 & 48.76500 & -115.66830 & NONE & $\mathrm{F}$ \\
\hline 17010103 & Yaak & East Fork Yaak River & 24-Jul-2001 & 48.93390 & -115.45340 & NONE & $\mathrm{F}$ \\
\hline 17010103 & Yaak & Green Creek & 23-Jul-2007 & 48.87000 & -115.95000 & NONE & $\mathrm{F}$ \\
\hline 17010103 & Yaak & Hubbard Creek & 23-Jul-2007 & 48.94300 & -115.48000 & NONE & $\mathrm{F}$ \\
\hline 17010103 & Yaak & Lap Creek & 23-Jul-2007 & 48.88288 & -115.66396 & NONE & $\mathrm{F}$ \\
\hline 17010103 & Yaak & Pete Creek & 14-Aug-1992 & 48.90000 & -115.81000 & WEPE & $\mathrm{D}$ \\
\hline 17010103 & Yaak & Pete Creek & 23-Jul-2007 & 48.85000 & -115.77000 & NONE & $\mathrm{F}$ \\
\hline 17010103 & Yaak & Pete Creek & 23-Jul-2007 & 48.90000 & -115.81000 & WEPE & $\mathrm{D}$ \\
\hline 17010103 & Yaak & Seventeenmile Creek & 23-Jul-2007 & 48.63000 & -115.72000 & NONE & $\mathrm{F}$ \\
\hline 17010103 & Yaak & Seventeenmile Creek & 25-Jul-2007 & 48.67678 & -115.81902 & NONE & $\mathrm{F}$ \\
\hline 17010103 & Yaak & Seventeenmile Creek & 25-Jul-2007 & 48.63730 & -115.72032 & NONE & $\mathrm{F}$ \\
\hline 17010103 & Yaak & $\begin{array}{l}\text { Seventeenmile North } \\
\text { Fork }\end{array}$ & 23-Jul-2007 & 48.66000 & -115.76000 & NONE & $\mathrm{F}$ \\
\hline 17010103 & Yaak & Smoot Creek & 23-Jul-2007 & 48.72000 & -115.64000 & NONE & $\mathrm{F}$ \\
\hline 17010103 & Yaak & Spread Creek & 23-Jul-2007 & 48.91000 & -115.99000 & NONE & $\mathrm{F}$ \\
\hline 17010103 & Yaak & Turner Creek & 12-Jul-2004 & 48.86452 & -115.58420 & WEPE & $\mathrm{D}$ \\
\hline 17010103 & Yaak & Vinal Creek & 13-Jul-2004 & 48.86426 & -115.58639 & WEPE & $\mathrm{D}$ \\
\hline 17010103 & Yaak & West Fork Yaak River & 5-Aug-2005 & 48.95255 & -115.61042 & WEPE & $\mathrm{H}$ \\
\hline 17010103 & Yaak & Yaak River & 4-Aug-2005 & 48.82761 & -115.81282 & WEPE & $\mathrm{D}$ \\
\hline
\end{tabular}




\begin{tabular}{|c|c|c|c|c|c|c|c|}
\hline 17010103 & Yaak & Yaak River & 5-Aug-2005 & 48.64450 & -115.88620 & WEPE & $\mathrm{D}$ \\
\hline 17010103 & Yaak & Yaak River East Fork & 23-Jul-2007 & 48.94000 & -115.54000 & NONE & $\mathrm{F}$ \\
\hline 17010103 & Yaak & Yaak River East Fork & 23-Jul-2007 & 48.93282 & -115.45085 & NONE & $\mathrm{F}$ \\
\hline 17010103 & Yaak & Yaak River South Fork & 23-Jul-2007 & 48.79000 & -115.66000 & NONE & $\mathrm{F}$ \\
\hline 17010104 & Yaak & Yaak River & 5-Aug-2005 & 48.56106 & -115.97762 & WEPE & $\mathrm{D}$ \\
\hline 17010201 & Upper Clark Fork & Browns Gulch Creek & 21-Aug-2009 & 46.13467 & -112.57754 & NONE & $\mathrm{F}$ \\
\hline 17010201 & Upper Clark Fork & Browns Gulch Creek & 21-Aug-2009 & 46.06047 & -112.61490 & WEPE & A \\
\hline 17010201 & Upper Clark Fork & Browns Gulch Creek & 21-Aug-2009 & 46.12165 & -112.62153 & WEPE & $\mathrm{B}$ \\
\hline 17010201 & Upper Clark Fork & Browns Gulch Creek & 21-Aug-2009 & 46.01361 & -112.68658 & NONE & $\mathrm{F}$ \\
\hline 17010201 & Upper Clark Fork & Browns Gulch Creek & 21-Aug-2009 & 46.12998 & -112.60614 & WEPE & $\mathrm{B}$ \\
\hline 17010201 & Upper Clark Fork & Browns Gulch Creek & 21-Aug-2009 & 46.13365 & -112.58031 & NONE & $\mathrm{F}$ \\
\hline 17010201 & Upper Clark Fork & Browns Gulch Creek & 21-Aug-2009 & 46.13519 & -112.57650 & NONE & $\mathrm{F}$ \\
\hline 17010201 & Upper Clark Fork & Dog Creek & 3-Sep-2007 & 46.64205 & -112.37243 & NONE & $\mathrm{F}$ \\
\hline 17010201 & Upper Clark Fork & Little Blackfoot River & 24-Jul-2007 & 46.56671 & -112.67125 & NONE & $\mathrm{F}$ \\
\hline 17010201 & Upper Clark Fork & Little Blackfoot River & 3-Sep-2007 & 46.59653 & -112.58721 & NONE & $\mathrm{F}$ \\
\hline 17010201 & Upper Clark Fork & Little Blackfoot River & 3-Sep-2007 & 46.59514 & -112.59203 & NONE & $\mathrm{F}$ \\
\hline 17010201 & Upper Clark Fork & Little Blackfoot River & 3-Sep-2007 & 46.57863 & -112.52690 & NONE & $\mathrm{F}$ \\
\hline 17010201 & Upper Clark Fork & Little Blackfoot River & 3-Sep-2007 & 46.56287 & -112.42737 & NONE & $\mathrm{F}$ \\
\hline 17010201 & Upper Clark Fork & Little Blackfoot River & 5-Sep-2007 & 46.51953 & -112.79340 & NONE & $\mathrm{F}$ \\
\hline 17010201 & Upper Clark Fork & Little Blackfoot River & 5-Sep-2007 & 46.42200 & -112.48700 & NONE & $\mathrm{F}$ \\
\hline 17010201 & Upper Clark Fork & Little Blackfoot River & 3-May-2008 & 46.59524 & -112.59172 & NONE & $\mathrm{F}$ \\
\hline 17010201 & Upper Clark Fork & $\begin{array}{l}\text { Little Blackfoot Spring } \\
\text { Creek }\end{array}$ & 3-May-2008 & 46.60795 & -112.55464 & NONE & $\mathrm{F}$ \\
\hline 17010201 & Upper Clark Fork & Spotted Dog Creek & 3-Sep-2007 & 46.50862 & -112.56565 & NONE & $\mathrm{F}$ \\
\hline 17010201 & Upper Clark Fork & Warm Springs Creek & 2-Oct-2008 & 46.13759 & -112.89201 & NONE & $\mathrm{F}$ \\
\hline 17010201 & Upper Clark Fork & Warm Springs Creek & 2-Oct-2008 & 46.13648 & -112.89615 & NONE & $\mathrm{F}$ \\
\hline 17010201 & Upper Clark Fork & Warm Springs Creek & 29-Oct-2008 & 46.13400 & -112.95321 & NONE & $\mathrm{F}$ \\
\hline 17010201 & Upper Clark Fork & Warm Springs Creek & 29-Oct-2008 & 46.13570 & -112.96898 & NONE & $\mathrm{F}$ \\
\hline 17010201 & Upper Clark Fork & Warm Springs Creek & 29-Oct-2008 & 46.14228 & -112.99227 & NONE & $\mathrm{F}$ \\
\hline 17010201 & Upper Clark Fork & Warm Springs Creek & 29-Oct-2008 & 46.17470 & -113.15617 & NONE & $\mathrm{F}$ \\
\hline 17010201 & Upper Clark Fork & Warm Springs Creek & 29-Oct-2008 & 45.45440 & -113.29940 & NONE & $\mathrm{F}$ \\
\hline 17010202 & Flint-Rock & Barnes Creek & 27-Aug-2008 & 46.61089 & -113.16017 & NONE & $\mathrm{F}$ \\
\hline 17010202 & Flint-Rock & Bowles Creek & 3-Jul-2007 & 46.19289 & -113.75200 & NONE & $\mathrm{F}$ \\
\hline 17010202 & Flint-Rock & Copper Creek & 3-Jul-2007 & 46.05487 & -113.56688 & NONE & $\mathrm{F}$ \\
\hline 17010202 & Flint-Rock & Copper Creek & 3-Jul-2007 & 46.04586 & -113.58806 & NONE & $\mathrm{F}$ \\
\hline 17010202 & Flint-Rock & Deep Creek & 17-Jul-2007 & 46.79803 & -113.29928 & NONE & $\mathrm{F}$ \\
\hline 17010202 & Flint-Rock & Deep Creek & 17-Jul-2007 & 46.79813 & -113.29884 & NONE & $\mathrm{F}$ \\
\hline 17010202 & Flint-Rock & Dempsy Creek & 19-Aug-2003 & 46.31002 & -112.93904 & NONE & $\mathrm{F}$ \\
\hline 17010202 & Flint-Rock & East Fork Rock Creek & 1-Jul-2007 & 46.19326 & -113.48547 & NONE & $\mathrm{F}$ \\
\hline 17010202 & Flint-Rock & Flint Creek & 1-Jul-2007 & 46.33779 & -113.32078 & NONE & $\mathrm{F}$ \\
\hline 17010202 & Flint-Rock & Flint Creek & 3-Jul-2007 & 46.36802 & -113.31720 & NONE & $\mathrm{F}$ \\
\hline 17010202 & Flint-Rock & Fred Burr Creek & 15-Jul-2007 & 46.29542 & -113.31710 & NONE & $\mathrm{F}$ \\
\hline 17010202 & Flint-Rock & Grizzly Creek & 1-Aug-2006 & 46.57458 & -113.65663 & NONE & $\mathrm{F}$ \\
\hline 17010202 & Flint-Rock & Lost Creek & 20-Jul-2003 & 46.16215 & -112.89142 & NONE & $\mathrm{F}$ \\
\hline 17010202 & Flint-Rock & Lost Creek & 28-Sep-2006 & 46.19652 & -112.98052 & NONE & $\mathrm{F}$ \\
\hline 17010202 & Flint-Rock & Lost Creek & 9-Oct-2008 & 46.19981 & -112.98721 & NONE & $\mathrm{F}$ \\
\hline
\end{tabular}




\begin{tabular}{|c|c|c|c|c|c|c|c|}
\hline 17010202 & Flint-Rock & Lost Creek & 29-Oct-2008 & 46.22097 & -113.02952 & NONE & $\mathrm{F}$ \\
\hline 17010202 & Flint-Rock & Lost Creek & 29-Oct-2008 & 46.19413 & -112.82108 & NONE & $\mathrm{F}$ \\
\hline 17010202 & Flint-Rock & Marshall Creek & 3-Jul-2007 & 46.36743 & -113.33273 & NONE & $\mathrm{F}$ \\
\hline 17010202 & Flint-Rock & Modesty Creek & 29-Oct-2008 & 46.23426 & -112.80697 & NONE & $\mathrm{F}$ \\
\hline 17010202 & Flint-Rock & Moose Meadows Creek & 31-Jul-2007 & 46.13685 & -113.58987 & WEPE & $\mathrm{C}$ \\
\hline 17010202 & Flint-Rock & North Fork Willow Creek & 3-Jul-2007 & 46.56842 & -113.35969 & WEPE & B \\
\hline 17010202 & Flint-Rock & North Fork Willow Creek & 3-Jul-2007 & 46.58419 & -113.41453 & NONE & $\mathrm{F}$ \\
\hline 17010202 & Flint-Rock & Racetrack Creek & 18-Aug-2003 & 46.27649 & -112.91758 & NONE & $\mathrm{F}$ \\
\hline 17010202 & Flint-Rock & Racetrack Creek & 28-Sep-2006 & 46.27618 & -112.91261 & NONE & $\mathrm{F}$ \\
\hline 17010202 & Flint-Rock & Ranch Creek & 17-Jul-2002 & 46.52565 & -113.62341 & NONE & $\mathrm{F}$ \\
\hline 17010202 & Flint-Rock & Rock Creek & 15-Jul-2004 & 46.69115 & -113.66260 & NONE & $\mathrm{F}$ \\
\hline 17010202 & Flint-Rock & Rock Creek & 19-Jul-2006 & 46.39796 & -113.68957 & WEPE & $\mathrm{H}$ \\
\hline 17010202 & Flint-Rock & Rock Creek & 1-Aug-2006 & 46.70719 & -113.67246 & NONE & $\mathrm{F}$ \\
\hline 17010202 & Flint-Rock & Rock Creek & 1-Aug-2006 & 47.03611 & -112.92361 & NONE & $\mathrm{F}$ \\
\hline 17010202 & Flint-Rock & Rock Creek & 1-Aug-2006 & 46.40818 & -112.96772 & NONE & $\mathrm{F}$ \\
\hline 17010202 & Flint-Rock & Rock Creek & 4-Sep-2007 & 46.70390 & -113.67357 & NONE & $\mathrm{F}$ \\
\hline 17010202 & Flint-Rock & Rock Creek & 4-Sep-2007 & 46.40818 & -112.96772 & NONE & $\mathrm{F}$ \\
\hline 17010202 & Flint-Rock & Sand Basin Creek & 3-Jul-2007 & 46.19628 & -113.69806 & WEPE & $\mathrm{C}$ \\
\hline 17010202 & Flint-Rock & Sand Basin Creek & 3-Jul-2007 & 46.19362 & -113.69407 & WEPE & $\mathrm{D}$ \\
\hline 17010202 & Flint-Rock & Stony Creek & 24-Jun-2004 & 46.33828 & -113.62765 & NONE & $\mathrm{F}$ \\
\hline 17010202 & Flint-Rock & Tenmile Creek & 16-Jul-2007 & 46.76221 & -113.37038 & NONE & $\mathrm{F}$ \\
\hline 17010202 & Flint-Rock & Tenmile Creek & 16-Jul-2007 & 46.76196 & -113.36937 & NONE & $\mathrm{F}$ \\
\hline 17010202 & Flint-Rock & Tin Cup Joe Creek & 19-Jul-2003 & 46.38581 & -112.89563 & NONE & $\mathrm{F}$ \\
\hline 17010202 & Flint-Rock & Trout Creek & 1-Jul-2007 & 46.21670 & -113.37675 & NONE & $\mathrm{F}$ \\
\hline 17010202 & Flint-Rock & Upper Willow Creek & 1-Jul-2007 & 46.41119 & -113.50617 & WEPE & B \\
\hline 17010202 & Flint-Rock & Upper Willow Creek & 1-Jul-2007 & 46.36704 & -113.49913 & WEPE & A \\
\hline 17010202 & Flint-Rock & Upper Willow Creek & 2-Jul-2007 & 46.51189 & -113.50991 & NONE & $\mathrm{F}$ \\
\hline 17010202 & Flint-Rock & West Fork Gold Creek & 25-Jun-2006 & 47.02147 & -113.77726 & NONE & $\mathrm{F}$ \\
\hline 17010202 & Flint-Rock & West Fork Rock Creek & 3-Jul-2002 & 46.19160 & -113.70210 & WEPE & $\mathrm{D}$ \\
\hline 17010202 & Flint-Rock & West Fork Rock Creek & 3-Jul-2007 & 46.19348 & -113.70742 & WEPE & $\mathrm{D}$ \\
\hline 17010202 & Flint-Rock & West Fork Rock Creek & 3-Jul-2007 & 46.21278 & -113.70087 & WEPE & $\mathrm{C}$ \\
\hline 17010202 & Flint-Rock & West Fork Rock Creek & 3-Jul-2007 & 46.20057 & -113.73115 & NONE & $\mathrm{F}$ \\
\hline 17010202 & Flint-Rock & West Fork Rock Creek & 3-Jul-2007 & 46.19816 & -113.74045 & NONE & $\mathrm{F}$ \\
\hline 17010202 & Flint-Rock & West Fork Rock Creek & 3-Jul-2007 & 46.20165 & -113.70170 & WEPE & B \\
\hline 17010203 & Blackfoot & Arrastra Creek & 8-Aug-2007 & 46.94601 & -112.90140 & NONE & $\mathrm{F}$ \\
\hline 17010203 & Blackfoot & Arrastra Creek & 8-Aug-2007 & 46.94628 & -112.90392 & NONE & $\mathrm{F}$ \\
\hline 17010203 & Blackfoot & Blackfoot River & 8-Aug-2007 & 46.91716 & -113.01432 & NONE & $\mathrm{F}$ \\
\hline 17010203 & Blackfoot & Blackfoot River & 8-Aug-2007 & 46.91872 & -113.01542 & NONE & $\mathrm{F}$ \\
\hline 17010203 & Blackfoot & Blackfoot River & 8-Aug-2007 & 46.93327 & -113.11469 & WEPE & $\mathrm{D}$ \\
\hline 17010203 & Blackfoot & Blackfoot River & 8-Aug-2007 & 46.94203 & -112.94815 & NONE & $\mathrm{F}$ \\
\hline 17010203 & Blackfoot & Blackfoot River & 8-Aug-2007 & 47.01341 & -112.45411 & NONE & $\mathrm{F}$ \\
\hline 17010203 & Blackfoot & Blackfoot River & 8-Aug-2007 & 46.94937 & -112.63248 & NONE & $\mathrm{F}$ \\
\hline 17010203 & Blackfoot & Blackfoot River & 5-Sep-2007 & 46.95305 & -112.60509 & NONE & $\mathrm{F}$ \\
\hline 17010203 & Blackfoot & Blackfoot River & 8-Sep-2007 & 46.89972 & -113.75623 & NONE & $\mathrm{F}$ \\
\hline 17010203 & Blackfoot & Blackfoot River & 27-Jul-2009 & 46.93635 & -112.77166 & NONE & $\mathrm{F}$ \\
\hline
\end{tabular}


Comprehensive Report on the Freshwater Mussels in Montana

\begin{tabular}{|c|c|c|c|c|c|c|c|}
\hline 17010203 & Blackfoot & Blackfoot River & 16-Oct-2009 & 47.01365 & -113.22305 & NONE & $\mathrm{F}$ \\
\hline 17010203 & Blackfoot & Buffalo Gulch & 5-Sep-2007 & 46.80307 & -112.76947 & WEPE & $\mathrm{D}$ \\
\hline 17010203 & Blackfoot & Chamberlain Creek & 28-Jul-2009 & 47.00877 & -113.25947 & NONE & $\mathrm{F}$ \\
\hline 17010203 & Blackfoot & Clearwater River & 9-Jul-2007 & 47.00088 & -113.38251 & NONE & $\mathrm{F}$ \\
\hline 17010203 & Blackfoot & Clearwater River & 9-Jul-2007 & 47.01927 & -113.38567 & NONE & $\mathrm{F}$ \\
\hline 17010203 & Blackfoot & Clearwater River & 9-Jul-2007 & 47.11993 & -113.44790 & NONE & $\mathrm{F}$ \\
\hline 17010203 & Blackfoot & Clearwater River & 9-Jul-2007 & 47.12185 & -113.44941 & NONE & $\mathrm{F}$ \\
\hline 17010203 & Blackfoot & Clearwater River & 9-Jul-2007 & 47.16471 & -113.49012 & NONE & $\mathrm{F}$ \\
\hline 17010203 & Blackfoot & Clearwater River & 10-Jul-2007 & 47.22252 & -113.53455 & WEPE & $\mathrm{C}$ \\
\hline 17010203 & Blackfoot & Clearwater River & 10-Jul-2007 & 47.22252 & -113.53455 & WEPE & B \\
\hline 17010203 & Blackfoot & Clearwater River & 10-Jul-2007 & 47.22252 & -113.53455 & WEPE & B \\
\hline 17010203 & Blackfoot & Clearwater River & 10-Jul-2007 & 47.22269 & -113.53553 & WEPE & B \\
\hline 17010203 & Blackfoot & Clearwater River & 10-Jul-2007 & 47.22230 & -113.53635 & WEPE & $\mathrm{B}$ \\
\hline 17010203 & Blackfoot & Clearwater River & 10-Jul-2007 & 47.22321 & -113.53679 & WEPE & A \\
\hline 17010203 & Blackfoot & Clearwater River & 10-Jul-2007 & 47.22398 & -113.53621 & WEPE & A \\
\hline 17010203 & Blackfoot & Clearwater River & 10-Jul-2007 & 47.22556 & -113.53704 & WEPE & A \\
\hline 17010203 & Blackfoot & Clearwater River & 10-Jul-2007 & 47.22758 & -113.53673 & WEPE & A \\
\hline 17010203 & Blackfoot & Clearwater River & 10-Jul-2007 & 47.23579 & -113.53827 & WEPE & A \\
\hline 17010203 & Blackfoot & Clearwater River & 10-Jul-2007 & 47.23618 & -113.53933 & NONE & $\mathrm{F}$ \\
\hline 17010203 & Blackfoot & Clearwater River & 10-Jul-2007 & 47.25202 & -113.58281 & NONE & $\mathrm{F}$ \\
\hline 17010203 & Blackfoot & Clearwater River & 10-Jul-2007 & 47.29912 & -113.57784 & NONE & $\mathrm{F}$ \\
\hline 17010203 & Blackfoot & Clearwater River & 10-Jul-2007 & 47.29856 & -113.57801 & NONE & $\mathrm{F}$ \\
\hline 17010203 & Blackfoot & Clearwater River & 10-Jul-2007 & 47.34721 & -113.58726 & NONE & $\mathrm{F}$ \\
\hline 17010203 & Blackfoot & Clearwater River & 10-Jul-2007 & 47.33496 & -113.59793 & NONE & $\mathrm{F}$ \\
\hline 17010203 & Blackfoot & Clearwater River & 10-Jul-2007 & 47.33348 & -113.59690 & WEPE & $\mathrm{D}$ \\
\hline 17010203 & Blackfoot & Clearwater River & 11-Jul-2007 & 47.35230 & -113.58255 & NONE & $\mathrm{F}$ \\
\hline 17010203 & Blackfoot & Clearwater River & 11-Jul-2007 & 47.11539 & -113.44242 & WEPE & C \\
\hline 17010203 & Blackfoot & Clearwater River & 11-Jul-2007 & 47.11602 & -113.44477 & WEPE & $\mathrm{C}$ \\
\hline 17010203 & Blackfoot & Clearwater River & 11-Jul-2007 & 46.96448 & -113.37910 & NONE & $\mathrm{F}$ \\
\hline 17010203 & Blackfoot & Clearwater River & 21-Jul-2009 & 47.23579 & -113.53827 & WEPE & A \\
\hline 17010203 & Blackfoot & Clearwater River & 21-Jul-2009 & 47.24316 & -113.54217 & WEPE & $\mathrm{C}$ \\
\hline 17010203 & Blackfoot & Clearwater River & 27-Jul-2009 & 47.24791 & -113.54636 & WEPE & A \\
\hline 17010203 & Blackfoot & Colt Creek & 11-Jun-2001 & 47.32610 & -113.59731 & WEPE & $\mathrm{D}$ \\
\hline 17010203 & Blackfoot & Colt Creek & 11-Jun-2001 & 47.32610 & -113.59731 & WEPE & C \\
\hline 17010203 & Blackfoot & Copper Creek & 8-Aug-2007 & 47.07877 & -112.61807 & NONE & $\mathrm{F}$ \\
\hline 17010203 & Blackfoot & Cottonwood Creek & 18-Jul-1996 & 46.86075 & -112.98865 & NONE & $\mathrm{F}$ \\
\hline 17010203 & Blackfoot & Cottonwood Creek & 18-Jul-1996 & 47.03691 & -113.26123 & NONE & $\mathrm{F}$ \\
\hline 17010203 & Blackfoot & Cottonwood Creek & 18-Jul-1996 & 47.05053 & -113.27153 & NONE & $\mathrm{F}$ \\
\hline 17010203 & Blackfoot & Cottonwood Creek & 18-Jul-1996 & 47.05200 & -113.27228 & NONE & $\mathrm{F}$ \\
\hline 17010203 & Blackfoot & Cottonwood Creek & 18-Jul-1996 & 47.03075 & -113.27275 & NONE & $\mathrm{F}$ \\
\hline 17010203 & Blackfoot & Cottonwood Creek & 18-Jul-1996 & 47.03075 & -113.27275 & NONE & $\mathrm{F}$ \\
\hline 17010203 & Blackfoot & Cottonwood Creek & 18-Jul-2007 & 47.03075 & -113.27275 & NONE & $\mathrm{F}$ \\
\hline 17010203 & Blackfoot & Cottonwood Creek & 18-Jul-2007 & 47.05063 & -113.27162 & NONE & $\mathrm{F}$ \\
\hline 17010203 & Blackfoot & Cottonwood Creek & 8-Aug-2007 & 47.06640 & -113.26408 & NONE & $\mathrm{F}$ \\
\hline 17010203 & Blackfoot & Cottonwood Creek & 8-Aug-2007 & 47.07723 & -113.25961 & NONE & $\mathrm{F}$ \\
\hline
\end{tabular}


Comprehensive Report on the Freshwater Mussels in Montana

\begin{tabular}{|c|c|c|c|c|c|c|c|}
\hline 17010203 & Blackfoot & Cottonwood Creek & 8-Aug-2007 & 47.06932 & -113.26540 & NONE & $\mathrm{F}$ \\
\hline 17010203 & Blackfoot & Cottonwood Creek & 8-Aug-2007 & 47.09462 & -113.29182 & NONE & $\mathrm{F}$ \\
\hline 17010203 & Blackfoot & Cottonwood Creek & 17-Aug-2007 & 47.09701 & -113.29578 & NONE & $\mathrm{F}$ \\
\hline 17010203 & Blackfoot & Deer Creek & 10-Jul-2007 & 47.21022 & -113.54196 & NONE & $\mathrm{F}$ \\
\hline 17010203 & Blackfoot & Douglas Creek & 8-Aug-2007 & 46.86053 & -113.00547 & NONE & $\mathrm{F}$ \\
\hline 17010203 & Blackfoot & $\begin{array}{l}\text { East Fork Clearwater } \\
\text { Creek }\end{array}$ & 11-Jul-2007 & 47.35994 & -113.56518 & NONE & $\mathrm{F}$ \\
\hline 17010203 & Blackfoot & Grentier Spring Creek & 28-Jul-2009 & 46.93565 & -112.68891 & NONE & $\mathrm{F}$ \\
\hline 17010203 & Blackfoot & Marshall Creek & 27-Jul-2009 & 47.29009 & -113.63799 & WEPE & A \\
\hline 17010203 & Blackfoot & Marshall Creek & 27-Jul-2009 & 47.28830 & -113.62739 & WEPE & B \\
\hline 17010203 & Blackfoot & Marshall Creek & 27-Jul-2009 & 47.28594 & -113.62383 & WEPE & B \\
\hline 17010203 & Blackfoot & Marshall Creek & 27-Jul-2009 & 47.28219 & -113.61845 & WEPE & B \\
\hline 17010203 & Blackfoot & Marshall Creek & 27-Jul-2009 & 47.28007 & -113.59894 & NONE & $\mathrm{F}$ \\
\hline 17010203 & Blackfoot & Marshall Creek & 27-Jul-2009 & 47.28334 & -113.65980 & NONE & $\mathrm{F}$ \\
\hline 17010203 & Blackfoot & Marshall Creek & 27-Jul-2009 & 47.28538 & -113.62321 & WEPE & B \\
\hline 17010203 & Blackfoot & McCabe Creek & 28-Jul-2009 & 47.08078 & -113.14413 & NONE & $\mathrm{F}$ \\
\hline 17010203 & Blackfoot & Monture Creek & 8-Aug-2007 & 47.03767 & -113.22010 & NONE & $\mathrm{F}$ \\
\hline 17010203 & Blackfoot & Monture Creek & 28-Jul-2009 & 47.02410 & -113.22828 & NONE & $\mathrm{F}$ \\
\hline 17010203 & Blackfoot & Monture Creek & 28-Jul-2009 & 47.10997 & -113.14990 & NONE & $\mathrm{F}$ \\
\hline 17010203 & Blackfoot & Monture Creek & 28-Jul-2009 & 47.11885 & -113.14661 & NONE & $\mathrm{F}$ \\
\hline 17010203 & Blackfoot & Morrell Creek & 9-Jul-2007 & 47.15962 & -113.46703 & NONE & $\mathrm{F}$ \\
\hline 17010203 & Blackfoot & Nevada Creek & 9-Jul-2007 & 46.75822 & -112.70388 & NONE & $\mathrm{F}$ \\
\hline 17010203 & Blackfoot & Nevada Creek & 9-Jul-2007 & 46.75842 & -112.70247 & WEPE & $\mathrm{H}$ \\
\hline 17010203 & Blackfoot & Nevada Creek & 9-Jul-2007 & 46.75853 & -112.70369 & WEPE & $\mathrm{H}$ \\
\hline 17010203 & Blackfoot & Nevada Creek & 26-Jul-2007 & 46.76487 & -112.63307 & NONE & $\mathrm{F}$ \\
\hline 17010203 & Blackfoot & Nevada Creek & 8-Aug-2007 & 46.80941 & -112.83030 & NONE & $\mathrm{F}$ \\
\hline 17010203 & Blackfoot & Nevada Creek & 8-Aug-2007 & 46.83218 & -112.89674 & WEPE & $\mathrm{D}$ \\
\hline 17010203 & Blackfoot & Owl Creek & 9-Jul-2007 & 47.11599 & -113.45740 & WEPE & $\mathrm{D}$ \\
\hline 17010203 & Blackfoot & Owl Creek & 9-Jul-2007 & 47.11505 & -113.47259 & WEPE & $\mathrm{D}$ \\
\hline 17010203 & Blackfoot & Owl Creek & 9-Jul-2007 & 47.11003 & -113.49761 & NONE & $\mathrm{F}$ \\
\hline 17010203 & Blackfoot & Placid Creek & 9-Jul-2007 & 47.14449 & -113.59538 & NONE & $\mathrm{F}$ \\
\hline 17010203 & Blackfoot & Sauerkraut Creek & 24-Sep-2009 & 46.91637 & -112.75499 & WEPE & C \\
\hline 17010203 & Blackfoot & Seeley Creek & 24-Jul-2007 & 47.21052 & -113.45428 & NONE & $\mathrm{F}$ \\
\hline 17010203 & Blackfoot & Shanley Creek & 18-Jul-2007 & 47.09708 & -113.22614 & NONE & $\mathrm{F}$ \\
\hline 17010203 & Blackfoot & Shanley Creek & 18-Jul-2007 & 47.07700 & -113.25124 & NONE & $\mathrm{F}$ \\
\hline 17010203 & Blackfoot & Ward Creek & 28-Jul-2009 & 46.96965 & -112.99063 & NONE & $\mathrm{F}$ \\
\hline 17010203 & Blackfoot & $\begin{array}{l}\text { West Fork Clearwater } \\
\text { River }\end{array}$ & 8-Aug-2007 & 47.25432 & -113.55446 & WEPE & $\mathrm{C}$ \\
\hline 17010203 & Blackfoot & $\begin{array}{l}\text { West Fork Clearwater } \\
\text { River }\end{array}$ & 27-Jul-2009 & 47.30364 & -113.60519 & NONE & $\mathrm{F}$ \\
\hline 17010203 & Blackfoot & $\begin{array}{l}\text { West Fork Clearwater } \\
\text { River }\end{array}$ & 27-Jul-2009 & 47.25224 & -113.58344 & NONE & $\mathrm{F}$ \\
\hline 17010203 & Blackfoot & $\begin{array}{l}\text { West Fork Clearwater } \\
\text { River }\end{array}$ & 27-Jul-2009 & 47.28249 & -113.59881 & NONE & $\mathrm{F}$ \\
\hline 17010203 & Blackfoot & Willow Creek & 8-Aug-2007 & 46.98611 & -112.39014 & NONE & $\mathrm{F}$ \\
\hline 17010203 & Blackfoot & Willow Creek & 16-Oct-2009 & 46.90181 & -112.72081 & NONE & $\mathrm{F}$ \\
\hline 17010204 & Middle Clark Fork & Butler Creek & 12-Jul-2006 & 47.12561 & -114.43692 & NONE & $\mathrm{F}$ \\
\hline 17010204 & Middle Clark Fork & Clark Fork River & 3-Aug-2006 & 47.01450 & -114.73930 & NONE & $\mathrm{F}$ \\
\hline
\end{tabular}




\begin{tabular}{|c|c|c|c|c|c|c|c|}
\hline 17010204 & Middle Clark Fork & Clark Fork River & 4-Sep-2007 & 47.19611 & -114.89019 & NONE & $\mathrm{F}$ \\
\hline 17010204 & Middle Clark Fork & Clark Fork River & 4-Sep-2007 & 47.35580 & -114.78333 & NONE & $\mathrm{F}$ \\
\hline 17010204 & Middle Clark Fork & Clark Fork River & 4-Sep-2007 & 46.88258 & -113.93120 & NONE & $\mathrm{F}$ \\
\hline 17010204 & Middle Clark Fork & Clark Fork River & 4-Sep-2007 & 46.87425 & -114.06660 & NONE & $\mathrm{F}$ \\
\hline 17010204 & Middle Clark Fork & Clark Fork River & 4-Sep-2007 & 46.93124 & -114.21036 & NONE & $\mathrm{F}$ \\
\hline 17010204 & Middle Clark Fork & Clark Fork River & 4-Sep-2007 & 47.02327 & -114.33588 & WEPE & $\mathrm{H}$ \\
\hline 17010204 & Middle Clark Fork & Clark Fork River & 4-Sep-2007 & 47.02810 & -114.39460 & WEPE & $\mathrm{H}$ \\
\hline 17010204 & Middle Clark Fork & Clark Fork River & 5-Sep-2007 & 47.29611 & -115.09028 & WEPE & $\mathrm{H}$ \\
\hline 17010204 & Middle Clark Fork & Clark Fork River & 5-Sep-2007 & 46.66121 & -113.14857 & WEPE & $\mathrm{H}$ \\
\hline 17010204 & Middle Clark Fork & Clark Fork River & 5-Sep-2007 & 47.22133 & -114.96070 & WEPE & $\mathrm{H}$ \\
\hline 17010204 & Middle Clark Fork & Clark Fork River & 5-Sep-2007 & 47.34047 & -114.77957 & WEPE & $\mathrm{H}$ \\
\hline 17010204 & Middle Clark Fork & Coyle Creek & 2-Aug-2006 & 47.25786 & -115.27180 & NONE & $\mathrm{F}$ \\
\hline 17010204 & Middle Clark Fork & East Fork Big Creek & 1-Aug-2006 & 47.29391 & -115.45517 & NONE & $\mathrm{F}$ \\
\hline 17010204 & Middle Clark Fork & East Fork Big Creek & 2-Aug-2006 & 47.30211 & -115.45261 & NONE & $\mathrm{F}$ \\
\hline 17010204 & Middle Clark Fork & East Fork Burnt Creek & 25-Jul-2008 & 47.22985 & -114.61612 & NONE & $\mathrm{F}$ \\
\hline 17010204 & Middle Clark Fork & Hoodoo Creek & 2-Aug-2006 & 46.98697 & -115.01195 & NONE & $\mathrm{F}$ \\
\hline 17010204 & Middle Clark Fork & Kennedy Creek & 12-Jul-2006 & 47.16473 & -114.42344 & NONE & $\mathrm{F}$ \\
\hline 17010204 & Middle Clark Fork & Kennedy Creek trib & 12-Jul-2006 & 47.15278 & -114.42696 & NONE & $\mathrm{F}$ \\
\hline 17010204 & Middle Clark Fork & Lake Creek & 3-Aug-2006 & 46.98803 & -114.99716 & NONE & $\mathrm{F}$ \\
\hline 17010204 & Middle Clark Fork & Lodgepole Creek & 1-Aug-2006 & 47.31766 & -115.44801 & NONE & $\mathrm{F}$ \\
\hline 17010204 & Middle Clark Fork & Lodgepole Creek trib & 1-Aug-2006 & 47.31109 & -115.43465 & NONE & $\mathrm{F}$ \\
\hline 17010204 & Middle Clark Fork & McCormick Creek & 24-Jul-2003 & 47.15250 & -114.48667 & NONE & $\mathrm{F}$ \\
\hline 17010204 & Middle Clark Fork & Ninemile Creek & 2-Aug-1993 & 47.03764 & -114.39330 & NONE & $\mathrm{F}$ \\
\hline 17010204 & Middle Clark Fork & Ninemile Creek & 12-Jul-2006 & 47.08190 & -114.43920 & NONE & $\mathrm{F}$ \\
\hline 17010204 & Middle Clark Fork & Ninemile Creek & 3-Sep-2007 & 47.08151 & -114.43902 & WEPE & $\mathrm{H}$ \\
\hline 17010204 & Middle Clark Fork & Ninemile Creek & 3-Sep-2007 & 47.16500 & -114.55780 & WEPE & $\mathrm{H}$ \\
\hline 17010204 & Middle Clark Fork & Ninemile Creek & 19-Jul-2008 & 47.11618 & -114.50076 & WEPE & $\mathrm{D}$ \\
\hline 17010204 & Middle Clark Fork & $\begin{array}{l}\text { North Fork Second } \\
\text { Creek }\end{array}$ & 3-Aug-2006 & 47.16404 & -114.71135 & NONE & $\mathrm{F}$ \\
\hline 17010204 & Middle Clark Fork & Soldier Creek & 25-Jul-2008 & 47.22214 & -114.59896 & NONE & $\mathrm{F}$ \\
\hline 17010204 & Middle Clark Fork & South Fork Trout Creek & 23-Jul-2008 & 46.95398 & -114.96809 & NONE & $\mathrm{F}$ \\
\hline 17010204 & Middle Clark Fork & Spruce Creek & 2-Aug-2006 & 47.31486 & -115.48841 & NONE & $\mathrm{F}$ \\
\hline 17010204 & Middle Clark Fork & Stony Creek & 12-Jul-2006 & 47.10939 & -114.39593 & NONE & $\mathrm{F}$ \\
\hline 17010204 & Middle Clark Fork & Stony Creek & 23-Jul-2008 & 47.07278 & -114.42806 & NONE & $\mathrm{F}$ \\
\hline 17010204 & Middle Clark Fork & trib to McCormick Creek & 12-Jul-2006 & 47.17323 & -114.42976 & NONE & $\mathrm{F}$ \\
\hline 17010204 & Middle Clark Fork & Trout Creek & 23-Jul-2008 & 47.04462 & -114.95147 & NONE & $\mathrm{F}$ \\
\hline 17010204 & Middle Clark Fork & trib to Lodgepole Creek & 1-Aug-2006 & 47.31589 & -115.43356 & NONE & $\mathrm{F}$ \\
\hline 17010204 & Middle Clark Fork & McKinney Creek & 1-Aug-2006 & 47.32606 & -115.42636 & NONE & $\mathrm{F}$ \\
\hline 17010204 & Middle Clark Fork & Van Ness Creek & 2-Aug-2006 & 47.08209 & -114.93553 & NONE & $\mathrm{F}$ \\
\hline 17010204 & Middle Clark Fork & Windfall Creek & 23-Jul-2008 & 47.03820 & -114.92846 & NONE & $\mathrm{F}$ \\
\hline 17010205 & Middle Clark Fork & Ambrose Creek & 26-Jul-2007 & 46.32306 & -113.54037 & NONE & $\mathrm{F}$ \\
\hline 17010205 & Bitterroot River & Ambrose Creek & 26-Jul-2007 & 46.32344 & -113.55051 & NONE & $\mathrm{F}$ \\
\hline 17010205 & Bitterroot River & Bitterroot River & 11-Jul-2006 & 46.58520 & -114.06706 & NONE & $\mathrm{F}$ \\
\hline 17010205 & Bitterroot River & Bitterroot River & 11-Jul-2006 & 46.52085 & -114.10860 & NONE & $\mathrm{F}$ \\
\hline 17010205 & Bitterroot River & Bitterroot River & 13-Jul-2007 & 46.85225 & -114.10003 & NONE & $\mathrm{F}$ \\
\hline 17010205 & Bitterroot River & Bitterroot River & 25-Aug-2007 & 45.98253 & -114.15110 & NONE & $\mathrm{F}$ \\
\hline
\end{tabular}




\begin{tabular}{|c|c|c|c|c|c|c|c|}
\hline 17010205 & Bitterroot River & Bitterroot River & 25-Aug-2007 & 46.75465 & -114.06207 & NONE & $\mathrm{F}$ \\
\hline 17010205 & Bitterroot River & Bitterroot River & 25-Aug-2007 & 46.72191 & -114.04672 & NONE & $\mathrm{F}$ \\
\hline 17010205 & Bitterroot River & Bitterroot River & 25-Aug-2007 & 46.00901 & -114.09854 & WEPE & C \\
\hline 17010205 & Bitterroot River & Bitterroot River & 4-Sep-2007 & 46.35000 & -114.04120 & WEPE & $\mathrm{H}$ \\
\hline 17010205 & Bitterroot River & Bitterroot River & 4-Sep-2007 & 46.58230 & -114.06271 & WEPE & $\mathrm{H}$ \\
\hline 17010205 & Bitterroot River & Bitterroot River & 4-Sep-2007 & 46.56785 & -114.09166 & WEPE & $\mathrm{H}$ \\
\hline 17010205 & Bitterroot River & Bitterroot River & 12-Sep-2007 & 46.84098 & -114.06646 & WEPE & $\mathrm{H}$ \\
\hline 17010205 & Bitterroot River & Bitterroot River & 27-Jun-2009 & 46.77048 & -114.05929 & WEPE & $\mathrm{H}$ \\
\hline 17010205 & Bitterroot River & $\begin{array}{l}\text { Burnt Fork Bitterroot } \\
\text { River }\end{array}$ & 20-Jul-2003 & 46.38484 & -113.86330 & NONE & $\mathrm{F}$ \\
\hline 17010205 & Bitterroot River & $\begin{array}{l}\text { Burnt Fork Bitterroot } \\
\text { River }\end{array}$ & 2-Aug-2007 & 46.24244 & -113.54135 & NONE & $\mathrm{F}$ \\
\hline 17010205 & Bitterroot River & $\begin{array}{l}\text { Burnt Fork Bitterroot } \\
\text { River }\end{array}$ & 2-Aug-2007 & 46.23459 & -113.54072 & NONE & $\mathrm{F}$ \\
\hline 17010205 & Bitterroot River & Cameron Creek & 10-Jul-2007 & 45.50171 & -113.58545 & WEPE & C \\
\hline 17010205 & Bitterroot River & Cameron Creek & 25-Sep-2007 & 45.53401 & -113.57242 & WEPE & B \\
\hline 17010205 & Bitterroot River & Daly Creek trib & 30-Jun-2007 & 46.23273 & -113.84638 & NONE & $\mathrm{F}$ \\
\hline 17010205 & Bitterroot River & Deer Creek & 20-Sep-2007 & 45.58947 & -114.34072 & NONE & $\mathrm{F}$ \\
\hline 17010205 & Bitterroot River & East Fork Bitterroot River & 20-Jul-2007 & 45.85906 & -114.02213 & WEPE & C \\
\hline 17010205 & Bitterroot River & East Fork Bitterroot River & 5-Sep-2007 & 45.85906 & -114.02213 & WEPE & $\mathrm{D}$ \\
\hline 17010205 & Bitterroot River & East Fork Bitterroot River & 5-Sep-2007 & 45.86590 & -113.87117 & NONE & $\mathrm{F}$ \\
\hline 17010205 & Bitterroot River & East Fork Bitterroot River & 5-Sep-2007 & 45.86083 & -114.02809 & WEPE & $\mathrm{H}$ \\
\hline 17010205 & Bitterroot River & East Fork Bitterroot River & 28-Sep-2007 & 45.55777 & -113.43451 & NONE & $\mathrm{F}$ \\
\hline 17010205 & Bitterroot River & Gilbert Creek & 21-Sep-2007 & 45.51491 & -114.04399 & NONE & $\mathrm{F}$ \\
\hline 17010205 & Bitterroot River & Gold Creek & 2-Aug-2007 & 46.23399 & -113.54066 & NONE & $\mathrm{F}$ \\
\hline 17010205 & Bitterroot River & Howard Creek & 16-Aug-2006 & 46.77636 & -114.53292 & WEPE & $\mathrm{D}$ \\
\hline 17010205 & Bitterroot River & Laird Creek & 21-Sep-2007 & 45.51390 & -114.04086 & NONE & $\mathrm{F}$ \\
\hline 17010205 & Bitterroot River & $\begin{array}{l}\text { Little Sleeping Child } \\
\text { Creek }\end{array}$ & 4-Aug-2005 & 46.12450 & -114.12697 & WEPE & $\mathrm{H}$ \\
\hline 17010205 & Bitterroot River & $\begin{array}{l}\text { Little Sleeping Child } \\
\text { Creek }\end{array}$ & 11-Jul-2007 & 46.07594 & -114.07321 & WEPE & B \\
\hline 17010205 & Bitterroot River & $\begin{array}{l}\text { Little Sleeping Child } \\
\text { Creek }\end{array}$ & 21-Aug-2007 & 46.06138 & -114.06039 & NONE & $\mathrm{F}$ \\
\hline 17010205 & Bitterroot River & Lodgepole Creek & 27-Sep-2007 & 45.50289 & -113.48788 & NONE & $\mathrm{F}$ \\
\hline 17010205 & Bitterroot River & Lolo Creek & 18-Aug-2005 & 46.74326 & -114.15562 & NONE & $\mathrm{F}$ \\
\hline 17010205 & Bitterroot River & Lolo Creek & 18-Aug-2005 & 46.74340 & -114.15599 & NONE & $\mathrm{F}$ \\
\hline 17010205 & Bitterroot River & Lolo Creek & 10-Jul-2006 & 46.76618 & -114.34048 & NONE & $\mathrm{F}$ \\
\hline 17010205 & Bitterroot River & Lost Horse Creek & 11-Jul-2007 & 46.06030 & -114.15307 & NONE & $\mathrm{F}$ \\
\hline 17010205 & Bitterroot River & McCalla Creek & 5-Sep-2007 & 46.51403 & -114.11837 & NONE & $\mathrm{F}$ \\
\hline 17010205 & Bitterroot River & Meadow Creek & 26-Sep-2007 & 45.51959 & -113.48256 & NONE & $\mathrm{F}$ \\
\hline 17010205 & Bitterroot River & Meadow Creek & 26-Sep-2007 & 45.51124 & -113.49237 & NONE & $\mathrm{F}$ \\
\hline 17010205 & Bitterroot River & Meadow Creek & 26-Sep-2007 & 45.49759 & -113.48106 & NONE & $\mathrm{F}$ \\
\hline 17010205 & Bitterroot River & Mill Creek tributary & 11-Jul-2006 & 46.72103 & -114.22024 & NONE & $\mathrm{F}$ \\
\hline 17010205 & Bitterroot River & Moose Meadows Creek & 18-Aug-2005 & 46.13685 & -113.58987 & WEPE & C \\
\hline 17010205 & Bitterroot River & Mormon Creek & 11-Jul-2006 & 46.71799 & -114.14264 & NONE & $\mathrm{F}$ \\
\hline 17010205 & Bitterroot River & Nez Perce Creek & 20-Sep-2007 & 45.46270 & -114.20119 & NONE & $\mathrm{F}$ \\
\hline 17010205 & Bitterroot River & O'Brien Creek & 29-Jun-2004 & 46.85126 & -114.17085 & NONE & $\mathrm{F}$ \\
\hline 17010205 & Bitterroot River & Rye Creek & 21-Aug-2007 & 45.97678 & -114.01243 & NONE & $\mathrm{F}$ \\
\hline 17010205 & Bitterroot River & Sawmill Creek & 2-Aug-2007 & 46.26506 & -113.54140 & NONE & $\mathrm{F}$ \\
\hline
\end{tabular}




\begin{tabular}{|c|c|c|c|c|c|c|c|}
\hline 17010205 & Bitterroot River & Skalkaho Creek & 22-Aug-2007 & 46.09315 & -113.57514 & NONE & $\mathrm{F}$ \\
\hline 17010205 & Bitterroot River & Skalkaho Creek & 22-Aug-2007 & 46.09433 & -113.57048 & NONE & $\mathrm{F}$ \\
\hline 17010205 & Bitterroot River & Slate Creek & 4-Sep-2007 & 45.69782 & -114.28660 & NONE & $\mathrm{F}$ \\
\hline 17010205 & Bitterroot River & Sleeping Child Creek & 12-Jul-2007 & 46.07559 & -114.03288 & NONE & $\mathrm{F}$ \\
\hline 17010205 & Bitterroot River & Sleeping Child Creek & 12-Jul-2007 & 46.07483 & -114.02524 & NONE & $\mathrm{F}$ \\
\hline 17010205 & Bitterroot River & Sleeping Child Creek & 12-Jul-2007 & 46.08072 & -114.04032 & NONE & $\mathrm{F}$ \\
\hline 17010205 & Bitterroot River & Swift Creek & 26-Sep-2007 & 45.53298 & -113.45964 & NONE & $\mathrm{F}$ \\
\hline 17010205 & Bitterroot River & Threemile Creek & 2-Aug-2007 & 46.37162 & -113.54498 & NONE & $\mathrm{F}$ \\
\hline 17010205 & Bitterroot River & Threemile Creek & 2-Aug-2007 & 46.36460 & -113.52502 & NONE & $\mathrm{F}$ \\
\hline 17010205 & Bitterroot River & Two Bear Creek & 12-Jul-2007 & 46.06433 & -114.00292 & NONE & $\mathrm{F}$ \\
\hline 17010205 & Bitterroot River & Warm Springs Creek & 24-Sep-2007 & 45.49438 & -114.03809 & NONE & $\mathrm{F}$ \\
\hline 17010205 & Bitterroot River & $\begin{array}{l}\text { West Fork Bitterroot } \\
\text { River }\end{array}$ & 2-Sep-1992 & 45.92963 & -114.13320 & NONE & $\mathrm{F}$ \\
\hline 17010205 & Bitterroot River & $\begin{array}{l}\text { West Fork Bitterroot } \\
\text { River }\end{array}$ & 4-Sep-2007 & 45.93132 & -114.13190 & NONE & $\mathrm{F}$ \\
\hline 17010205 & Bitterroot River & $\begin{array}{l}\text { West Fork Bitterroot } \\
\text { River }\end{array}$ & 4-Sep-2007 & 45.92777 & -114.13366 & NONE & $\mathrm{F}$ \\
\hline 17010205 & Bitterroot River & $\begin{array}{l}\text { West Fork Bitterroot } \\
\text { River }\end{array}$ & 4-Sep-2007 & 45.76585 & -114.28195 & NONE & $\mathrm{F}$ \\
\hline 17010205 & Bitterroot River & $\begin{array}{l}\text { West Fork Bitterroot } \\
\text { River }\end{array}$ & 4-Sep-2007 & 45.62424 & -114.30359 & NONE & $\mathrm{F}$ \\
\hline 17010205 & Bitterroot River & $\begin{array}{l}\text { West Fork Bitterroot } \\
\text { River }\end{array}$ & 4-Sep-2007 & 45.62169 & -114.30546 & NONE & $\mathrm{F}$ \\
\hline 17010205 & Bitterroot River & $\begin{array}{l}\text { West Fork Bitterroot } \\
\text { River }\end{array}$ & 4-Sep-2007 & 45.62165 & -114.30388 & NONE & $\mathrm{F}$ \\
\hline 17010205 & Bitterroot River & $\begin{array}{l}\text { West Fork Bitterroot } \\
\text { River }\end{array}$ & 4-Sep-2007 & 45.62509 & -114.30269 & NONE & $\mathrm{F}$ \\
\hline 17010205 & Bitterroot River & $\begin{array}{l}\text { West Fork Bitterroot } \\
\text { River }\end{array}$ & 4-Sep-2007 & 45.59342 & -114.32278 & NONE & $\mathrm{F}$ \\
\hline 17010205 & Bitterroot River & $\begin{array}{l}\text { West Fork Bitterroot } \\
\text { River }\end{array}$ & 4-Sep-2007 & 45.66772 & -114.30425 & NONE & $\mathrm{F}$ \\
\hline 17010205 & Bitterroot River & $\begin{array}{l}\text { West Fork Bitterroot } \\
\text { River }\end{array}$ & 4-Sep-2007 & 45.81490 & -114.25336 & NONE & $\mathrm{F}$ \\
\hline 17010205 & Bitterroot River & $\begin{array}{l}\text { West Fork Bitterroot } \\
\text { River }\end{array}$ & 5-Sep-2007 & 45.82698 & -114.23339 & WEPE & D \\
\hline 17010205 & Bitterroot River & $\begin{array}{l}\text { West Fork Bitterroot } \\
\text { River }\end{array}$ & 20-Sep-2007 & 45.80501 & -114.26225 & NONE & $\mathrm{F}$ \\
\hline 17010205 & Bitterroot River & $\begin{array}{l}\text { West Fork Bitterroot } \\
\text { River }\end{array}$ & 20-Sep-2007 & 45.48881 & -114.33167 & NONE & $\mathrm{F}$ \\
\hline 17010205 & Bitterroot River & $\begin{array}{l}\text { West Fork Bitterroot } \\
\text { River }\end{array}$ & 1-Sep-2008 & 45.37498 & -114.18149 & NONE & $\mathrm{F}$ \\
\hline 17010205 & Bitterroot River & West Fork Camp Creek & 24-Sep-2007 & 45.45229 & -113.56563 & NONE & $\mathrm{F}$ \\
\hline 17010205 & Bitterroot River & West Fork Lolo Creek & 30-Jun-2006 & 46.64400 & -114.58060 & NONE & $\mathrm{F}$ \\
\hline 17010205 & Bitterroot River & West Fork Lolo Creek & 18-Aug-2007 & 46.63892 & -114.58026 & NONE & $\mathrm{F}$ \\
\hline 17010205 & Bitterroot River & West Fork Lolo Creek & 5-Sep-2007 & 46.68550 & -114.55800 & NONE & $\mathrm{F}$ \\
\hline 17010205 & Bitterroot River & Willow Creek & 9-Jul-2007 & 46.17367 & -113.57517 & NONE & $\mathrm{F}$ \\
\hline 17010205 & Bitterroot River & Willow Creek & 9-Jul-2007 & 46.17313 & -113.56394 & NONE & $\mathrm{F}$ \\
\hline 17010206 & North Fork Flathead & Griffin Creek & 15-Aug-2002 & 48.28140 & -114.76336 & NONE & $\mathrm{F}$ \\
\hline 17010206 & North Fork Flathead & Griffin Creek & 1-Jul-2003 & 48.28140 & -114.76336 & NONE & $\mathrm{F}$ \\
\hline 17010206 & North Fork Flathead & $\begin{array}{l}\text { North Fork Flathead } \\
\text { River }\end{array}$ & 24-Jul-2001 & 48.83676 & -114.34407 & NONE & $\mathrm{F}$ \\
\hline 17010206 & North Fork Flathead & $\begin{array}{l}\text { North Fork Flathead } \\
\text { River }\end{array}$ & 24-Jul-2001 & 48.83676 & -114.34407 & NONE & $\mathrm{F}$ \\
\hline 17010207 & Middle Fork Flathead & Bull River & 12-Jul-2004 & 48.10509 & -115.77752 & WEPE & $\mathrm{D}$ \\
\hline 17010207 & Middle Fork Flathead & Schafer Creek & 11-Jul-2007 & 48.06390 & -113.24530 & NONE & $\mathrm{F}$ \\
\hline 17010207 & Middle Fork Flathead & Tunnel Creek & 16-Aug-2003 & 48.35910 & -113.67960 & NONE & $\mathrm{F}$ \\
\hline 17010208 & Flathead Lake & Ashley Creek & 23-Jul-2007 & 48.09517 & -114.55178 & WEPE & D \\
\hline
\end{tabular}




\begin{tabular}{|c|c|c|c|c|c|c|c|}
\hline 17010208 & Flathead Lake & Crow Creek & 1-Jul-1900 & 47.48757 & -114.09666 & WEPE & $\mathrm{H}$ \\
\hline 17010209 & South Fork Flathead & Stony Creek & 16-Sep-1992 & 47.90656 & -113.57200 & NONE & $\mathrm{F}$ \\
\hline 17010210 & Stillwater & Stillwater River & 2-Sep-2009 & 48.60391 & -114.65698 & NONE & $\mathrm{F}$ \\
\hline 17010210 & Stillwater & Stillwater River & 2-Sep-2009 & 48.60896 & -114.65690 & NONE & $\mathrm{F}$ \\
\hline 17010210 & Stillwater & Stillwater River & 2-Sep-2009 & 48.64333 & -114.72487 & NONE & $\mathrm{F}$ \\
\hline 17010210 & Stillwater & Sunday Creek & 2-Sep-2009 & 48.63228 & -114.70886 & NONE & $\mathrm{F}$ \\
\hline 17010211 & Swan & Beaver Creek & 11-Jul-2007 & 47.38793 & -113.66017 & NONE & $\mathrm{F}$ \\
\hline 17010211 & Swan & Glacier Creek & 11-Jul-2007 & 47.52780 & -113.72174 & NONE & $\mathrm{F}$ \\
\hline 17010211 & Swan & Glacier Creek & 17-Sep-2009 & 47.42463 & -113.75504 & NONE & $\mathrm{F}$ \\
\hline 17010211 & Swan & Holland Creek & 17-Sep-2009 & 47.44061 & -113.61628 & NONE & $\mathrm{F}$ \\
\hline 17010211 & Swan & Holland Creek & 17-Sep-2009 & 47.44074 & -113.67444 & NONE & $\mathrm{F}$ \\
\hline 17010211 & Swan & Moose Creek & 23-Aug-2008 & 48.82479 & -114.52056 & NONE & $\mathrm{F}$ \\
\hline 17010211 & Swan & Smith Creek & 11-Jul-2007 & 47.58575 & -113.73970 & NONE & $\mathrm{F}$ \\
\hline 17010211 & Swan & Smith Creek trib & 11-Jul-2007 & 47.55184 & -113.69573 & NONE & $\mathrm{F}$ \\
\hline 17010211 & Swan & Swan River & 11-Jul-2007 & 47.58343 & -113.75767 & NONE & $\mathrm{F}$ \\
\hline 17010211 & Swan & Swan River & 11-Jul-2007 & 47.52750 & -113.71371 & NONE & $\mathrm{F}$ \\
\hline 17010211 & Swan & Swan River & 11-Jul-2007 & 47.46212 & -113.68449 & NONE & $\mathrm{F}$ \\
\hline 17010211 & Swan & Swan River & 11-Jul-2007 & 47.42132 & -113.67009 & NONE & $\mathrm{F}$ \\
\hline 17010211 & Swan & Swan River & 11-Jul-2007 & 47.67305 & -113.80998 & NONE & $\mathrm{F}$ \\
\hline 17010211 & Swan & Swan River & 12-Jul-2007 & 47.62986 & -113.78781 & NONE & $\mathrm{F}$ \\
\hline 17010211 & Swan & Swan River & 12-Jul-2007 & 47.40486 & -113.71703 & NONE & $\mathrm{F}$ \\
\hline 17010211 & Swan & Swan River & 17-Sep-2009 & 47.34313 & -113.74654 & NONE & $\mathrm{F}$ \\
\hline 17010211 & Swan & Swan River trib & 11-Jul-2007 & 47.52626 & -113.71267 & NONE & $\mathrm{F}$ \\
\hline 17010213 & Thompson & Bassoo Creek & 18-Jul-2004 & 47.83179 & -114.69409 & WEPE & B \\
\hline 17010213 & Thompson & Big Cherry Creek & 26-Aug-2008 & 48.24687 & -115.54945 & NONE & $\mathrm{F}$ \\
\hline 17010213 & Thompson & Bull River & 25-Jul-2007 & 48.13600 & -115.86681 & NONE & $\mathrm{F}$ \\
\hline 17010213 & Thompson & Camp Creek & 25-Aug-2008 & 47.48649 & -115.27064 & NONE & $\mathrm{F}$ \\
\hline 17010213 & Thompson & Chilly Creek & 27-Jul-2007 & 47.78800 & -115.29654 & NONE & $\mathrm{F}$ \\
\hline 17010213 & Thompson & Clark Fork River & 25-Aug-2008 & 47.61638 & -115.38979 & NONE & $\mathrm{F}$ \\
\hline 17010213 & Thompson & Cold Creek & 27-Jul-2007 & 47.79999 & -115.29596 & NONE & $\mathrm{F}$ \\
\hline 17010213 & Thompson & Dry Creek & 25-Aug-2008 & 47.58545 & -115.35644 & NONE & $\mathrm{F}$ \\
\hline 17010213 & Thompson & East Fork Dry Creek & 25-Aug-2008 & 47.55202 & -115.37578 & NONE & $\mathrm{F}$ \\
\hline 17010213 & Thompson & Freezeout Creek & 27-Jul-2007 & 47.77319 & -115.29857 & NONE & $\mathrm{F}$ \\
\hline 17010213 & Thompson & Graves Creek & 25-Aug-2008 & 47.71432 & -115.38213 & NONE & $\mathrm{F}$ \\
\hline 17010213 & Thompson & Graves Creek Trib & 27-Jul-2007 & 47.75041 & -115.29597 & NONE & $\mathrm{F}$ \\
\hline 17010213 & Thompson & Little Thompson River & 11-Aug-2008 & 47.69570 & -114.81110 & WEPE & $\mathrm{C}$ \\
\hline 17010213 & Thompson & Little Thompson River & 27-Aug-2008 & 47.71021 & -115.01349 & NONE & $\mathrm{F}$ \\
\hline 17010213 & Thompson & Little Thompson River & 27-Aug-2008 & 47.68608 & -114.99834 & NONE & $\mathrm{F}$ \\
\hline 17010213 & Thompson & McGinnus Creek & 26-Aug-2008 & 47.96296 & -115.21727 & NONE & $\mathrm{F}$ \\
\hline 17010213 & Thompson & McGinnus Creek & 26-Aug-2008 & 48.02557 & -115.24224 & NONE & $\mathrm{F}$ \\
\hline 17010213 & Thompson & Middle Fork Bull River & 27-Aug-2008 & 48.19341 & -115.81562 & NONE & $\mathrm{F}$ \\
\hline 17010213 & Thompson & Miller Creek & 25-Aug-2008 & 47.82482 & -115.30052 & NONE & $\mathrm{F}$ \\
\hline 17010213 & Thompson & Miller Lake & 25-Aug-2008 & 47.92495 & -115.27954 & NONE & $\mathrm{F}$ \\
\hline 17010213 & Thompson & Mudd Creek & 27-Aug-2008 & 47.66097 & -114.97547 & NONE & $\mathrm{F}$ \\
\hline 17010213 & Thompson & North Fork Bull River & 27-Aug-2008 & 48.19657 & -115.81025 & NONE & $\mathrm{F}$ \\
\hline
\end{tabular}




\begin{tabular}{|c|c|c|c|c|c|c|c|}
\hline 17010213 & Thompson & North Fork Clear Creek & 27-Aug-2008 & 47.61463 & -115.59437 & NONE & $\mathrm{F}$ \\
\hline 17010213 & Thompson & Pilgrim Creek & 27-Aug-2008 & 47.99571 & -115.76427 & WEPE & $\mathrm{D}$ \\
\hline 17010213 & Thompson & Sylvan Lake & 25-Aug-2008 & 47.91595 & -115.27975 & NONE & $\mathrm{F}$ \\
\hline 17010213 & Thompson & Thompson River & 25-Jul-2008 & 47.58890 & -115.23234 & NONE & $\mathrm{F}$ \\
\hline 17010213 & Thompson & Thompson River & 25-Jul-2008 & 47.60757 & -115.20541 & NONE & $\mathrm{F}$ \\
\hline 17010213 & Thompson & Thompson River & 25-Jul-2008 & 47.63075 & -115.17600 & NONE & $\mathrm{F}$ \\
\hline 17010213 & Thompson & Thompson River & 26-Aug-2008 & 47.94109 & -114.97532 & NONE & $\mathrm{F}$ \\
\hline 17010213 & Thompson & Thompson River & 27-Aug-2008 & 47.92030 & -115.00187 & WEPE & B \\
\hline 17010213 & Thompson & Thompson River & 27-Aug-2008 & 47.92114 & -115.00069 & WEPE & B \\
\hline 17010213 & Thompson & Thompson River & 27-Aug-2008 & 47.91160 & -115.04247 & WEPE & $\mathrm{D}$ \\
\hline 17010213 & Thompson & Thompson River & 27-Aug-2008 & 47.91048 & -115.04959 & WEPE & C \\
\hline 17010213 & Thompson & Thompson River & 27-Aug-2008 & 47.90018 & -115.04764 & WEPE & $\mathrm{D}$ \\
\hline 17010213 & Thompson & Thompson River & 27-Aug-2008 & 47.90153 & -115.04971 & NONE & $\mathrm{F}$ \\
\hline 17010213 & Thompson & Thompson River & 27-Aug-2008 & 47.86160 & -115.00150 & NONE & $\mathrm{F}$ \\
\hline 17010213 & Thompson & Thompson River & 27-Aug-2008 & 47.78402 & -115.00818 & NONE & $\mathrm{F}$ \\
\hline 17010213 & Thompson & Thompson River & 27-Aug-2008 & 47.73887 & -115.01690 & NONE & $\mathrm{F}$ \\
\hline 17010213 & Thompson & Thompson River & 27-Aug-2008 & 47.73879 & -115.01564 & WEPE & $\mathrm{D}$ \\
\hline 17010213 & Thompson & Thompson River & 27-Aug-2008 & 47.73972 & -115.01519 & WEPE & C \\
\hline 17010213 & Thompson & Twelvemile Creek & 25-Aug-2008 & 47.40879 & -115.25438 & NONE & $\mathrm{F}$ \\
\hline 17010213 & Thompson & Twelvemile Creek & 25-Aug-2008 & 47.47168 & -115.27621 & NONE & $\mathrm{F}$ \\
\hline 17010213 & Thompson & Twelvemile Creek & 25-Aug-2008 & 47.47275 & -115.26433 & NONE & $\mathrm{F}$ \\
\hline 17010213 & Thompson & Twelvemile Creek & 25-Aug-2008 & 47.47849 & -115.25275 & NONE & $\mathrm{F}$ \\
\hline 17010213 & Thompson & Vermilion River & 27-Jul-2007 & 47.84757 & -115.30053 & NONE & $\mathrm{F}$ \\
\hline 17010213 & Thompson & Vermilion River & 27-Jul-2007 & 47.80734 & -115.30029 & NONE & $\mathrm{F}$ \\
\hline 17010213 & Thompson & Vermilion River & 25-Aug-2008 & 47.81715 & -115.29924 & NONE & $\mathrm{F}$ \\
\hline 17010213 & Thompson & $\begin{array}{l}\text { West Fork Thompson } \\
\text { River }\end{array}$ & 25-Aug-2008 & 47.65791 & -115.18706 & NONE & $\mathrm{F}$ \\
\hline 17010213 & Thompson & $\begin{array}{l}\text { West Fork Thompson } \\
\text { River }\end{array}$ & 25-Aug-2008 & 47.65957 & -115.21176 & NONE & $\mathrm{F}$ \\
\hline 17010213 & Thompson & Willow Creek Vermillion & 25-Aug-2008 & 47.87138 & -115.31018 & NONE & $\mathrm{F}$ \\
\hline 17010213 & Thompson & Willow Creek Vermillion & 25-Aug-2008 & 47.87516 & -115.30041 & NONE & $\mathrm{F}$ \\
\hline 17060302 & Big Boulder & Big Boulder Creek & 10-Aug-2004 & 45.57600 & -116.06900 & NONE & $\mathrm{F}$ \\
\hline 17060302 & Big Boulder & El Dorado Creek & 8-Jul-2008 & 46.28161 & -115.70985 & WEPE & A \\
\hline 17060302 & Big Boulder & El Dorado Creek & 8-Jul-2008 & 46.29803 & -115.64506 & WEPE & B \\
\hline 17060302 & Big Boulder & El Dorado Creek & 8-Jul-2008 & 46.25852 & -115.69258 & WEPE & A \\
\hline 17060302 & Big Boulder & El Dorado Creek & 8-Jul-2008 & 46.25677 & -115.69375 & WEPE & C \\
\hline 17060302 & Big Boulder & Swamp Creek & 27-Aug-2004 & 46.75090 & -115.05416 & WEPE & $\mathrm{D}$ \\
\hline 17060306 & Musselshell, ID & Browns Creek & 6-Jul-2008 & 46.36608 & -115.79184 & NONE & $\mathrm{F}$ \\
\hline 17060306 & Musselshell, ID & Browns Creek & 7-Jul-2008 & 46.34484 & -115.78012 & WEPE & A \\
\hline 17060306 & Musselshell, ID & El Dorado Creek & 8-Jul-2008 & 46.28378 & -115.71257 & WEPE & B \\
\hline 17060306 & Musselshell, ID & El Dorado Creek & 8-Jul-2008 & 46.29843 & -115.64607 & WEPE & C \\
\hline 17060306 & Musselshell, ID & Lolo Creek & 6-Jul-2008 & 46.31645 & -115.74680 & WEPE & C \\
\hline 17060306 & Musselshell, ID & Musselshell Creek & 6-Jul-2008 & 46.35104 & -115.76110 & WEPE & A \\
\hline 17060306 & Musselshell, ID & Musselshell Creek & 7-Jul-2008 & 46.35143 & -115.76091 & WEPE & A \\
\hline 17060306 & Musselshell, ID & Musselshell Creek & 7-Jul-2008 & 46.34427 & -115.77849 & WEPE & A \\
\hline 17060306 & Musselshell, ID & Musselshell Creek & 7-Jul-2008 & 46.39093 & -115.74305 & WEPE & A \\
\hline
\end{tabular}


